This PDF is a selection from an out-of-print volume from the National Bureau of Economic Research

Volume Title: A Retrospective on the Classical Gold Standard, 1821-1931

Volume Author/Editor: Michael D. Bordo and Anna J. Schwartz, editors

Volume Publisher: University of Chicago Press

Volume ISBN: 0-226-06590-1

Volume URL: http://www.nber.org/books/bord84-1

Publication Date: 1984

Chapter Title: The Gold Standard: The Traditional Approach

Chapter Author: Michael D. Bordo

Chapter URL: http://www.nber.org/chapters/c11126

Chapter pages in book: (p. 23 - 120) 


\section{1 \\ The Gold Standard: The Traditional Approach}

Michael D. Bordo

\subsection{Introduction}

What was the traditional approach to the gold standard? In this paper, I try to provide an answer to the question by examining the works of major writers on the subject since the eighteenth century. ${ }^{2}$ The choice of writers and works surveyed is based on my judgment that the works encompassed a significant share of the content of the traditional approach and that the writers played a significant role in the history of economic thought.

Six major themes formed the traditional approach, and five major schools of thought may be identified.

\subsection{Major Themes in the Literature}

The first theme, which runs from Cantillon to present-day writers, was that gold (the precious metals) was an ideal monetary standard, domestically and internationally, because of its unique qualities both as a standard of value and a medium of exchange. A stable price level in the long run that an automatically operated gold standard produced, in line with the commodity theory of money, was invariably contrasted to the evils of inconvertible fiduciary money. At the hands of even well-meaning policymakers the latter would inevitably lead to depreciation of the value of money. However, most writers, following Adam Smith, emphasized the social saving from using fiduciary money instead of a commodity money

Michael David Bordo is professor of economics at the University of South Carolina and a research associate of the National Bureau of Economic Research.

For helpful comments and suggestions the author would like to thank Michael Connolly, John McDermott, Peter Lindert, Anna Schwartz, and Larry White; he would also like to thank Fernando Santos and Glen Vogt for able research assistance. 
and hence were concerned with the properties of a convertible (or mixed) standard to ensure price stability.

The second theme was the price-specie-flow mechanism. The essence of the gold standard was the maintenance of a fixed mint price of national money in terms of gold (achieved by specifying the weight of a nation's coinage in terms of gold). That rule ensured uniformity of the price of gold across nations (and regions) through the process of arbitrage in gold. ${ }^{2}$ Moreover, each country's price level was determined by its stock of monetary gold, which in turn was determined (naturally distributed) by the nation's real income and money-holding habits. Consequently, the price levels of all countries were linked together under the gold standard by the fixed definition of the monetary unit in terms of gold. Any disturbance away from the natural distribution of precious metals affecting one nation's (region's) price level, and hence the market price of gold, would inevitably lead to an equilibrating process through arbitrage in the gold market. Gold flows, by changing the nation's (region's) money supply, would then also change its level of prices.

For example, a gold discovery in one country would lead to an increase in its money supply, an increase in its price level, and a fall in the domestic market price of gold. The divergence between the domestic and world gold prices would quickly lead to a gold outflow, a contraction in the domestic money supply, and a fall of the domestic price level. An alternative way of viewing the same mechanism was to focus on the balance of trade-the rise in the domestic price level would raise prices of domestic goods and exports relative to prices of imports, leading to a balance-oftrade deficit, a gold outflow, and a contraction of the money supply.

Thus the price-specie-flow mechanism was the means by which arbitrage in one commodity-gold-between nations and regions, served to keep overall national (regional) price levels in line and to maintain balance-of-payments equilibrium. Within this context, different authors stressed the pattern of adjustment of particular classes of commodities. Thus Mill focused on the behavior of the prices of tradable goods relative to those of domestic (nontradable) goods. Others focused on the secondary role of changes in the exchange rate. To the extent that gold prices between nations could differ, reflecting transportation and other costs of transferring gold (the difference between the upper and lower bounds referred to as the gold points), changes in exchange rates (the domestic relative to the foreign price of gold) would also serve to equilibrate the balance of payments without requiring a gold flow. In addition, a number of writers focused on the role of real income in the adjustment mechanism-changes in the quantity of money consequent upon gold flows would affect total expenditure and income in addition to, or in some cases instead of, affecting prices. 
The third theme, which is intimately connected to the second, was the "law of one price"- the notion that arbitrage in individual traded commodities would ensure similar prices in a common currency for similar goods, taking account of transportation costs and trade impediments. Along these lines, a distinction was made between domestic (nontraded) goods whose prices are determined primarily by domestic forces and traded goods whose prices are determined by the world market.

One question is how to reconcile the law of one price with the pricespecie-flow mechanism, since the latter stressed primarily consequences of arbitrage in gold, while the former stressed arbitrage in all traded commodities. For the classical economists, it was assumed that arbitrage in gold was more effective than in other commodities because of gold's special properties; moreover, since gold served as the money supply (or as the monetary base), alterations in its quantity would impinge on all prices. Ultimately, which goods serve as vehicles for arbitrage is an empirical question. The answer depends on the total costs of arbitrage, including information costs. In the eighteenth and early nineteenth centuries, gold was the commodity with the lowest arbitrage costs, hence gold flows rapidly kept gold prices in line and other goods prices followed. Later in the nineteenth century, with improvements in communications technology and the development of international securities and commodity markets, arbitrage in securities and traded commodities reduced the role for gold flows in the adjustment mechanism.

The fourth theme was the role of capital flows in the gold standard balance-of-payments adjustment mechanism. The original conception of the price-specie-flow adjustment mechanism was that it operated through flows of goods and money, but by the middle of the nineteenth century, emphasis was also placed on the role of short-term capital flows as part of the equilibrating mechanism. According to the traditional approach, a decline (rise) in the domestic money stock led to a rise (fall) in short-term interest rates and consequently attracted funds from abroad. Thus in the example of a gold discovery, the increased money supply would reduce domestic interest rates relative to interest rates in other countries, producing both a short-term capital and gold outflow, thereby reducing the amount of adjustment required through changes in the domestic price level. As the nineteenth century wore on and world capital markets became more integrated, emphasis on the role of capital mobility increased to the point where it was regarded as the dominant adjustment mechanism.

In addition to short-term capital flows, the role of long-term capital flows was noted as a source of disturbance to the balance of payments. Thus one element of the traditional approach was the role of long-term lending by mature countries, such as England and France, to developing 
nations, such as the United States, Canada, and Argentina. Capital flows from the Old to the New World were also accompanied by gold flows, raising the price level in the capital-importing country and lowering it in the exporting country. The resultant change in relative price levels produced a current-account surplus in the capital-exporting country and a deficit in the importing country. Thus the transfer of capital resulted in a transfer of real resources. ${ }^{3}$ The process could continue for many years, with developing (developed) countries running a persistent balance-ofpayments deficit (surplus) on current account financed by long-term capital inflows (outflows).

The fifth theme, which focuses primarily on the performance of the Bank of England, was the role of central banks in helping or hindering the adjustment mechanism. This theme was a reflection of the British flavor of the gold standard literature and the key role played by the Bank of England in the analysis of the gold standard.

Several aspects of the central-bank theme may be noted. One was the debate over rules versus discretion. In the early part of the nineteenth century, emphasis was placed on the advantage of combining the automatic-monetary-rule aspect of the gold standard with the benefits of low-resource-cost fiduciary money. That approach culminated in the Bank Charter Act of 1844 and the separation of the Bank of England into the Issue Department, based on a gold standard rule, and the Banking Department, based on commercial-banking principles.

Second, several money-market crises and threats to convertibility in the succeeding quarter century led to attention in the literature to the Bank's disregard of domestic-money-market conditions in its operation as a private profit-maximizing institution following a gold standard rule. Thus the Bank, in keeping with its private role, would maintain as low a gold reserve as possible while using its Bank-rate weapon to protect its reserve from gold outflows. Bagehot's statement of the "responsibility doctrine" and a prescription for effective central-bank management, referred to as Bagehot's rule, emerged from the scrutiny of the Bank's behavior. A later development was the discussion of the inherent conflict between internal and external price stability under a fixed exchange rate such as the gold standard.

In addition, the gold standard came to be regarded as primarily managed by central banks' use of changes in the discoumt rate to facilitate adjustment to both internal and external gold drains. Among the issues stressed were: how Bank rate was made "effective," in the sense of inducing corresponding changes in market interest rates; the use of other policy tools to protect the gold reserves; the channels by which changes in Bank rate would affect the required adjustment in the balance of payments-by inducing short-term capital flows or by changing domestic price levels, economic activity, and the terms of trade. 
Finally, discussion turned on the extent to which central banks followed the "rules of the game," that is, used their policy tools to speed up the adjustment mechanism to an external shock. According to the rules, the central bank of a country experiencing a gold outflow (inflow) should engage in policies to contract (expand) the domestic money supply.

The sixth and final theme in the traditional approach was the advocacy of a number of proposals for reform. Many writers suggested schemes for reform of the gold standard both at the national and international levels.

At the national level, a persistent theme ranging from Thornton ([1802] 1978) to Keynes ([1923] 1971) was the importance of managing the gold standard so as to reduce the conflict between external and internal stability, i.e., for the central bank to intervene and shield the domestic money supply from external shocks. Related to this theme were schemes to protect the monetary gold stock from internal currency drains, e.g., Ricardo's gold-bullion standard. Finally, schemes were designed to separate the medium-of-exchange function of gold from the store-of-value function. All these proposals attempted to rectify an important defect of the gold standard-basing a nation's money supply on one commodity subject to changing demand and supply conditions. Schemes along these lines included creation of a tabular standard, bimetallism, symmetallism, and Fisher's (1920) compensated dollar.

At the international level, proposals designed to provide world price stability included schemes such as bimetallism, symmetallism, and the basing of international money on a wide commodity basket; and also, to ensure international harmony of price-level movements, they favored the creation of some form of supernational central bank.

\subsection{Schools of Thought}

On the basis both of common views and chronology, the five schools of thought on the gold standard are the classical school, the neoclassical school, the Harvard school, the interwar critics, and the post-World War II reinterpreters. A brief summary of the views of the leading exponents of each school follows. Detailed documentation of these views is provided in five appendixes, one for each school.

\subsubsection{Classical School}

Eight economists - Cantillon, Hume, Ricardo, Thornton, Mill, Cairnes, Goschen, and Bagehot-constituted the classical school. From the writings of these men we can distill the essence of the traditional approach. Cantillon developed the law of one price and aspects of the international adjustment mechanism. Hume is famous for the pricespecie-flow mechanism. Ricardo developed the natural distribution of precious metals and made contributions to issues related to the monetary 
standard and monetary reform. Mill, perhaps the key writer of the school, covered virtually all the major themes of the traditional view, and Cairnes tested some of the theoretical implications. Finally, Goschen focused on the role of short-term capital flows, while Bagehot outlined the principles of central-bank management under the gold standard.

\subsubsection{Neoclassical School}

Marshall, Fisher, and Wicksell of the neoclassical school extended and perfected the mechanisms analyzed by the classical school. They, however, explored some of the detrimental effects, both for individual nations and for the world, of adhering to the gold standard, and consequently the need for reform.

\subsubsection{Harvard School}

F. W. Taussig and his students (Viner, Graham, White, Williams, and Beach) attempted to formulate and test a more comprehensive version of the traditional balance-of-payments adjustment mechanism to the external disturbance of long-term capital movements by incorporating gold flows, changes in relative price levels, short-term capital flows, and changes in discount rates.

The evidence for the United States, Great Britain, France, Canada, and Argentina produced by this massive research project was largely inconclusive, and in many respects cast doubt on the traditional emphasis on relative price-level changes as the heart of the adjustment mechanism.

J. W. Angell, a critic of Taussig, integrated the law of one price in the relative price-specie-flow adjustment mechanism. Despite its critical approach, his work is classified as part of the Harvard-school studies.

\subsubsection{Interwar Critics}

After World War I, a number of writers considered the case for and against a return to the gold standard as it existed pre-World War I. Brown and Smit, accepting in the main the stylized facts of the gold standard as succinctly portrayed by the Cunliffe report (United Kingdom, Parliament [1918] 1979), assessed the gold standard as having been successful before World War I because it was a managed standardmanaged by London-and then documented the special institutional characteristics of the sterling standard. Keynes and Viner discussed the inherent policy conflict between adherence to the gold standard and domestic economic activity, and addressed a plea for more international cooperation. Whale cast doubt on the stylized facts of how the gold standard worked, suggesting that perhaps the traditional approach was incorrect. 


\subsubsection{Post-World War II Reinterpreters}

In the post-World War II period, scholars reexamined the operation of the classical gold standard on the basis of new evidence and new theoretical and statistical tools. The issues they stressed included the balance-ofpayments adjustment mechanism, capital flows, and rules of the game. The balance-of-payments adjustment mechanism under the gold standard was reexamined from a Keynesian perspective by Ford, from a modern quantity-theory perspective by Friedman and Schwartz, and from the perspective of the monetary approach to the balance of payments by Williamson, Triffin, and McCloskey and Zecher. The role of capital flows was reexamined by Morgenstern and Bloomfield. Finally the operation of central banks under the gold standard with respect to rules of the game was reconsidered by Sayers, Bloomfield, and Lindert.

\subsection{A Retrospective}

The development of the literature on the traditional approach can be viewed from a number of perspectives. I briefly sketch out the elements of two of them: the first, that the interpretation of the gold standard by each school reflected the policy concerns of the time; the second, that the evolution of the interpretation of the gold standard has many of the characteristics of a Kuhnian scientific revolution.

According to the first perspective, the development of the traditional approach by the classical economists was strongly influenced by the concern over finding the ideal monetary standard consistent with the classical principles of free enterprise and free trade. This concern thus explains the emphasis on the automatic qualities of the gold standard both as a national and an international standard, the operation of the commodity theory of money that would ensure long-run world price stability (in a stationary world), and the price-specie-flow mechanism that would ensure the natural distribution of precious metals and uniformity of price structures across the world. Behind this smoothly functioning monetary veil, real resources would be efficiently allocated to their best uses by the forces of competition between individuals and enterprises across the world. The introduction of the real-world problems of friction in the balance-of-payments adjustment mechanism and the possible conflict, at least in the short run, between the constraint of the gold standard and internal economic stability led to the development of rules of proper central-bank management of the gold standard.

The neoclassical economists, writing at a time when the gold standard was the prevailing standard, accepted its rationale, but concerned themselves with removing one of its major shortcomings-specifically, the tendency for the world price level to exhibit alternating swings of defla- 
tion and inflation, reflecting major shocks to the demand for and supply of gold.

The Harvard economists, like the neoclassicists, writing about the heyday of the gold standard, sought a better understanding of the mechanism by which one of the most important structural changes in modern economic history took place-the transfer of real resources associated with massive lending by the mature countries of Western Europe to the developing countries of the New World.

The interwar critics, writing after the collapse of the gold standard, yet strongly influenced by its heritage, were concerned with the possibility of restoring the old system. Much of their work reflected skepticism on this score because for them "special circumstances" in the prewar period made the system work: the unique interrelationship between the London gold, securities, and commodities markets that created a "sterling standard"; the commitment by major participants to maintain convertibility as their key policy goal; and relatively free trade and factor mobility. These special circumstances no longer existed.

Other interwar critics focused on the negative aspects of the gold standard: the tendency for short-run price instability, the asymmetry between the adjustment mechanism of central and peripheral countries, the conflict between external and internal stability, and the tendency for economic fluctuations to be transmitted internationally by the gold standard. Hence these interwar critics doubted the wisdom of returning to the standard's iron discipline. However, in elaborating proposals for a better system, the consensus favored maintaining a fixed-exchange-rate system based on gold, with expanded national discretionary management and the establishment of a supernational central bank.

Finally, in the postwar period, operating in an institutional environment far enough removed from the events before 1914, scholars of the gold standard could objectively ask how the gold standard in its many aspects worked. Armed with new theoretical and statistical tools and new compilations of data, the consensus of this work has been that the international gold standard did function smoothly in the sense of ensuring international price harmony, in allowing the international transfer of resources, and in maintaining balance-of-payments equilibria for most countries over long periods of time, but that many elements of the story-particularly the operation of the price-specie-flow mechanism and the importance of the rules of the game--were subject to doubt.

According to the second perspective, the development of the gold standard literature reflected a Kuhnian scientific revolution (Kuhn 1970).

Along this line, we start with the development of the classical-gold standard paradigm by the classical economists, culminating in the magnum opus of J. S. Mill. The paradigm was further extended and perfected by the neoclassical economists, especially Irving Fisher. However, anom- 
alies begin to appear by the end of the nineteenth century: the pricespecie-flow mechanism emphasizing the adjustment of relative price levels could not explain the actual adjustment process to international lending in a number of countries; in some cases the mechanism could be detected, in others the adjustment of price levels between countries seemed to be too rapid for the theory; and it appeared that many countries did not follow the rules of the game but engaged in extensive sterilization activities. However, the reaction to these anomalies by Taussig and others was to incorporate them into the theory as special cases. The assault on the classical paradigm began in the interwar period with the grave doubts raised by Keynes, Williams, Cassel, and others, but it was probably the 1937 article by Whale, challenging the whole classical interpretation of how the gold standard worked, that started the revolution. The further revelation of evidence inconsistent with the classical story in the postwar period added ammunition to the case presented by Williamson, Triffin, and finally McCloskey and Zecher. The last authors completely upended the classical paradigm and argued passionately that all aspects of the gold standard could be explained by the newly developed monetary approach. The scientific revolution was complete.

In conclusion, we can ask: Is this the end of the gold standard story? McCloskey and Zecher, in tying together much of the unfavorable evidence against the traditional approach and then reinterpreting the facts to be consistent with the implications of the monetary approach to the balance of payments, make a strong case for a successful conclusion, except that the evidence they marshal in favor of their approach, based largely on correlation tests of commodity arbitrage, is neither extensive nor conclusive enough to end the story.

\section{Appendix A The Classical Economists}

In this appendix the writings of eight key economists who first formulated the tenets of the traditional approach to the gold standard are summarized: ${ }^{4}$ Cantillon, Hume, Ricardo, Thornton, Mill, Cairnes, Goschen, and Bagehot.

\section{Richard Cantillon}

Richard Cantillon ([1931] 1964), writing in 1755, was one of the first writers to analyze the working of a money economy. Operating within a crude quantity-theory-of-money framework, ${ }^{5}$ Cantillon regarded the quantity of money as consisting entirely of specie-gold and silver coins. Gold and silver emerged as money commodities as a result of the evolution of natural market forces-they best satisfied the properties of 
money, viz., they are "of small volume, equal goodness, easily transported, divisible without loss, convenient to keep, beautiful and brilliant in the articles made of them and durable almost to eternity" (Cantillon [1931] 1964, p. 111). Moreover, the choice between gold and silver (as well as the desired ratio in a bimetallic system) is determined by market forces—on the demand side by tastes and income, on the supply side by relative scarcity (pp. 97 and 277). In the long run, the world's monetary specie stock as well as its exchange value is determined by the foregone cost in terms of the land and labor required to extract precious metals. ${ }^{6}$ In the short run, the two key sources of a nation's money supply are its balance-of-payments surplus and the presence of domestic gold and silver mines (bk. 2, chaps. 6, 7).

Perhaps Cantillon's most important contribution was setting out a dynamic version of the quantity theory of money or what has often been referred to as monetary-disequilibrium theory. Cantillon carefully analyzed the dynamic process by which the quantity of money affected economic activity and the price level. An important element of his analysis was the international repercussions in the specie-standard world of fixed exchange rates of domestically induced monetary change:

If more money continues to be drawn from the Mines all prices will owing to this abundance rise to such a point that . . . there will be a considerable profit in buying them [goods] from the foreigner who makes them much more cheaply. This will naturally induce several people to import many manufactured articles made in foreign countries, where they will be found very cheap: this will gradually ruin the Mechanics and Manufacturers of the State. (P. 165).

That is, domestic inflation, by raising the prices of domestically-produced goods relative to foreign-produced goods (changing the terms of trade), will generate a balance-of-trade deficit. This deficit will induce a specie outflow, a reduction in the domestic money stock, and a reduction in domestic output and prices-the price-specie-flow mechanism.

In addition to the terms-of-trade effect, the balance of payments will adjust by a direct-expenditure effect. According to this mechanism, an excess supply of money will cause domestic expenditures to exceed income; some of this expenditure will be made directly on foreignproduced goods (whose prices are determined abroad), leading to a specie outflow:

It is usual in States which have acquired a considerable abundance of money to draw many things from neighbouring countries where money is rare and consequently everything is cheap: but as money must be sent for this the balance of trade will become smaller. (P. 169)

Cantillon's final main contribution to the traditional view' was a clear statement of the law of one price—commodity arbitrage will ensure that 
the prices of similar traded goods will be the same across countries and across regions within countries, allowing for the influence of tariffs and transportation costs.

The difference of prices in the Capital and in the Provinces must pay for the costs and risks of transport, otherwise cash will be sent to the Capital to pay the balance and this will go on till the prices in the Capital and the Provinces come to the level of these costs and risks. (P. 151)

Moreover, he clearly distinguished between traded and nontraded goods on the basis of trade impediments and transportation costs. Thus the prices of traded goods that are determined abroad will be largely unaffected by domestic monetary conditions, whereas the prices of nontraded goods will respond fully, viz.

In England it is always permitted to bring in corn from foreign countries, but not cattle. For this reason however great the increase of hard money may be in England the price of corn can only be raised above the price in other countries where money is scarce by the costs and risks of importing corn from these foreign countries.

It is not the same with the price of Cattle, which will necessarily be proportioned to the quantity of money offered for Meat in proportion to the quantity of Meat and the number of Cattle bred there. (P. 179)

This suggests that the distinction between the terms of trade and the direct-expenditure mechanisms rests on the distinction between tradedand nontraded-goods prices. The excess-money-induced expenditure falls on both traded and nontraded goods. To the extent the expenditure affects nontraded goods, their prices rise, inducing the substitution of traded goods. To the extent it affects traded goods whose prices are determined abroad, it leads to a direct specie outflow. Presumably, the effect on nontraded-goods prices will be short-lived-until substitution and the decline in the domestic money supply consequent upon the specie outflow have caused the relative prices of traded and nontraded goods to return to their initial equilibrium.

\section{David Hume}

In his essay, "Of the Balance of Trade" ([1752] 1955), Hume is generally believed to have originated the theory of the traditional balance-ofpayments adjustment mechanism of an international specie standard (see Viner 1937, pp. 291-92). According to Hume, a domestic monetary disturbance such as a sudden decrease in the specie stock will lead to a proportional decline in all prices and wages, a consequent decline in the prices of exports relative to the prices of imports, a balance-of-payments surplus, a specie inflow, and an increase in the domestic stock of specie. 
Suppose four-fifths of all the money in Great Britain to be annihilated in one night, . . . what would be the consequence? Must not the price of all labour and commodities sink in proportion . . . ? What nation could then dispute with us in any foreign market, or pretend to navigate or to sell manufactures at the same price, which to us would afford sufficient profit? In how little time, therefore, must this bring back the money which we had lost, and raise us to the level of all the neighboring nations? Where, after we have arrived, we immediately lose the advantage of the cheapness of labour and commodities; and the farther flowing in of money is stopped by our fulness and repletion. (Hume [1752] 1955, pp. 62-63)

Thus, the domestic specie stock in a country (or province within a country) under a specie standard will be automatically regulated by its balance of payments. Moreover, this mechanism will ensure that each nation's (province's) price level will be consistent with adherence to the specie standard.

In addition, variations in the exchange rate within the gold points will act as an additional factor to correct balance-of-payments disequilibria.

There is another cause, though more limited in its operation, which checks the wrong balance of trade, to every particular nation to which the kingdom trades. When we import more goods than we export, the exchange turns against us, and this becomes a new encouragement to export; as much as the charge of carriage and insurance of the money which becomes due would amount to. For the exchange can never rise but a little higher than that sum. (P. 64n)

Hume also discussed the law of one price, viz.

any man who travels over Europe at this day, may see, by the prices of commodities, that money . . . has brought itself nearly to a level; and that the difference between one kingdom and another is not greater in this respect, than it is often between different provinces of the same kingdom. . . The only circumstances which can obstruct the exactness of these proportions [between money and real economic activity] is the expense of transporting the commodities from one place to another. (P. 66)

Some writers have argued that there appeared to be an inconsistency between the law of one price, which suggests rapid adjustment of commodity prices through arbitrage, and the price-specie-flow mechanism which suggests noticeable time lags. ${ }^{8}$ However, as is made most clear by Ricardo, the price-specie-flow mechanism is a reflection of arbitrage in the gold market, which, because of its special properties, is more rapid than arbitrage in other markets. Other prices are kept in line through the influence of changes in the quantity of gold as money. In accordance with this interpretation, Hume may have regarded the law of one price as a 
long-run equilibrium condition in all markets with the price-specie-flow mechanism as the means to achieve that result.

\section{David Ricardo \\ Gold as the Standard}

Ricardo ([1811] 1951, [1816] 1951), in the classical tradition, viewed the world quantity of specie as determined in the long run by cost of production (Ricardo [1811] 1951, p. 52). The quantity of precious metals used as money in each country depended "first, on its value;--secondly, on the amount or value of the payments to be made;--and, thirdly, on the degree of economy practiced in effecting those payments" (Ricardo [1816] 1951, p. 55).

Each country's share of the world specie stock and hence the natural distribution of precious metals is determined by its share of world real income and factors determining velocity (or the demand for money).

The precious metals employed for circulating the commodities of the world, ... have been divided into certain proportions among the different civilized nations of the earth, according to the state of their commerce and wealth, and therefore according to the number and frequency of the payments which they had to perform. While so divided they preserved everywhere the same value, and as each country had an equal necessity for the quantity actually in use, there could be no temptation offered to either for their importation or exportation. ([1811] 1951, p. 52)

The choice of gold and silver as monetary standard was "the comparative steadiness in the value of the precious metals, for periods of some duration" ([1816] 1951, p. 55). In the choice between gold and silver, gold has in its favor "its greater value under a smaller bulk" which "qualifies it for the standard in an opulent country," but coupled with the disadvantage that it is subject to "greater variations of value during periods of war or extensive commercial discredit." Silver he viewed as "much more steady in its value, in consequence of its demand and supply being more regular." The only objection to its use as a standard "is its bulk, which renders it unfit for the large payments required in a wealthy country" ( $p$. 63).

However, using both precious metals as the standard has the disadvantage that prices expressed in terms of gold and silver will vary with changing demand and supply conditions for each commodity. To avoid this instability, Ricardo suggested the substitution of paper money and "by the judicious management of the quantity, a degree of uniformity . . . is secured" (pp. 57-58). In addition, the substitution of bank notes for specie "enables us to turn the precious metals (which, though a very 
necessary part of our capital, yield no revenue) into a capital which will yield one" ([1811] 1951, p. 55). However, "the issuers of paper money should regulate their issues solely by the price of bullion" ([1816] 1951, p. 64). Indeed, for Ricardo, the key advantage of the gold standard was that adherence to the standard acted as a check against the overissue of paper money-it provided discipline (p. 78).

\section{Balance-of-Payments Adjustment Mechanism}

Beginning with the natural distribution of precious metals, Ricardo demonstrated how this distribution would be neutral with respect to monetary changes. Any movement away from the natural distribution would be corrected by the price-specie-flow mechanism. Thus if a gold mine were discovered in one country

the currency of that country would be lowered in value in consequence of the increased quantity of the precious metals brought into circulation, and would therefore no longer be of the same value as that of other countries. Gold and silver, whether in coin or in bullion, obeying the law which regulates all other commodities, would immediately become articles of exportation; they would leave the country where they were cheap, for those countries where they were dear, and would continue to do so, as long as the mine should prove productive, and till the proportion existing between capital and money in each country before the discovery of the mine, were again established, and gold and silver restored every where to one value. In return for the gold exported, commodities would be imported; and though what is usually termed the Balance of Trade would be against the country exporting money or bullion, it would be evidence that she was carrying on a most advantageous trade, exporting that which was no way useful to her, for commodities which might be employed in the extension of her manufactures, and the increase of her wealth. (Ricardo [1811] 1951, p. 54) ${ }^{10}$

Thus gold as a commodity flows to the market with the highest price and thereby maintains price uniformity between nations.

As long as different countries (regions within countries) fixed the prices of their currencies in terms of gold (specified a gold weight of their coins), then arbitrage allowing for transportation costs would always keep gold prices in line ${ }^{11}$ This principle, referred to as the law of one price, would hold for all traded commodities, and hence in logic there was no reason why commodity arbitrage would not occur for all commodities. However, for Ricardo and other classical economists, arbitrage took place primarily in gold because of its special properties as money and because it involved the lowest arbitrage costs. Consequently since all other commodity prices were set in terms of gold-the numeraire of the system-gold flows would then keep all prices in line for countries (regions) on a gold standard. However, some prices would react more quickly to the mechanism than 
others, specifically prices of tradable goods, and this quick reaction probably explains the later emphasis in the literature on the role of changes in sectional prices and the terms of trade (see appendix B on Marshall).

Ricardo clearly distinguished between the adjustment mechanism under the gold standard and under irre deemable paper money. An issue of convertible paper currency, e.g., Bank of England notes, will displace, through the balance of payments, a corresponding amount of specie (p. 67). However, as long as convertibility in terms of gold is maintained, the domestic price level will not be affected. ${ }^{12}$ Once all specie is displaced and convertibility suspended, however, domestic prices will rise, and a depreciated exchange rate will be the indicator of overissue (pp. 58-59, 63-64, 72-78). In the Bullion report ([1810] 1978, pp. ccxvii-ccxxi), a distinction is made between the real exchange rate-determined by the ratio of the mint prices of gold between two gold standard countries-and the market exchange rate or the computed par. The market exchange rate includes both the influence of real factors causing a divergence from par within the gold points and the depreciation of the exchange rate (premium on the price of gold) due to a rise in the price level.

Thus for Ricardo, the increase in irredeemable paper following the suspension of payments in 1797 was responsible for both a rise in all commodity prices in England with no corresponding rise in prices abroad and the depreciation of the pound (pp. ccxiv-ccxv).

\section{Proposals for Monetary Reform}

As mentioned above, Ricardo viewed a properly regulated convertible paper currency as superior to a precious-metals standard. However, he believed that convertibility into gold was necessary to avoid the temptation of overissue (Ricardo [1816] 1951, p. 69).

And in the Bullion report ([1810] 1978, p. ccxlvi) a strong case is made in favor of a gold standard rule and against discretionary monetary policy:

The most detailed knowledge of the actual trade of the country, combined with the profound science in all the principles of money and circulation, would not enable any man or set of men to adjust, and keep always adjusted, the right proportion of circulating medium in a country to the wants of trade. When the currency consists entirely of the precious metals, or of paper convertible at will into the precious metals, the natural process of commerce, by establishing exchanges among all the different countries of the world, adjusts, in every particular country, the proportion of circulating medium to its actual occasions, according to that supply of the precious metals which the mines furnish to the general market of the world. The proportion, which is thus adjusted and maintained by the natural operation of commerce, 
cannot be adjusted by any human wisdom or skill. If the natural system of currency and circulation be abandoned, and a discretionary issue of paper money substituted in its stead, it is vain to think that any rules can be devised for the exact exercise of such a discretion.

As a remedy for defects of a purely metallic standard with no discretion for central bankers, he proposed a convertible banknote issue backed by bullion (Ricardo [1816] 1951, p. 66).

Free export and import of bullion would be permissible. Under this scheme the costs of frequent conversions of coin into bullion would be eliminated, but the risks of attempted conversion of banknotes into specie in a money-market panic would not be. ${ }^{13}$

\section{Henry Thornton}

\section{The Gold Standard}

Like Ricardo, Thornton ([1802] 1978, p. 21a) viewed convertibility as a key feature of the gold standard. ${ }^{14}$ Also, like Ricardo, he viewed the substitution of paper money for specie up to the point of convertibility as a social saving. However, he extended the analysis to consider the effects of a domestic issue of bank notes on the world price level.

First, since the issue of paper money would displace specie in the domestic circulation, specie would be exported abroad, leading to an increase in the world money stock and a rise in world prices. The country displacing specie would thereby raise its capital stock (Thornton [1802] 1978, pp. 269-70).

Second, to the extent the use of paper money reduced the demand for gold as money, and hence the price of bullion, this development would cause "those mines which have not yielded any rent, to be no longer worked; and the supply of gold . . . to be in consequence, somewhat reduced." The process would continue until

all mines will be unable to defray the charge of extracting the ore, except those which now yield the very highest rent. At this point the fall will necessarily stop . . . gold and silver must continue to bear that price, or nearly that price, . . . at which they are now exchangeable for commodities. (P. 266)

\section{Balance-of-Payments Adjustment Mechanism}

Thornton clearly elucidated the price-specie-flow mechanism. The primary mechanism of adjustment following an increase in the domestic money supply (an increase in Bank of England note issue) is the effect on prices at home relative to those abroad.

It is obvious, that in proportion as goods are rendered dear in Great Britain, the foreigner becomes unwilling to buy them, the commodities of other countries which come into competition with our's obtaining a 
preference in the foreign market; and, therefore, that in consequence of a diminution of orders from abroad, our exports will be diminished. ... But not only will our exports lessen . . . ; our imports also will increase; for the high British price of goods will tempt foreign commodities to come in nearly in the same degree in which it will discourage British articles from going out. (Thornton [1802] 1978, p. 198)

The resultant deficit in the balance of payments will however be offset to a certain extent by changes in the exchange rate within the gold points. However, to the extent an unfavorable balance persists and the exchange rate falls to the specie-export point, this will lead to a specie outflow until trade balance is restored (pp. 145-47).

Finally, Thornton discussed an alternative adjustment mechanism-the direct-expenditure-income mechanism:

There is in the mass of the people . . . a disposition to adapt their individual expenditure to their income. Importations conducted with a view to the consumption of the country into which the articles are imported . . . are limited by the ability of the individuals of that country to pay for them out of their income. . . If, therefore, . . the value of the annual income of the inhabitants of a country is diminished, either new economy on the one hand, or new exertions of individual industry on the other, fail not, after a certain time, in some measure, to restore the balance. And this equality between private expenditures and private incomes tends ultimately to produce equality between the commercial exports and imports. (Pp. 142-43)

\section{Law of One Price}

According to Thornton, different prices within Great Britain for identical goods cannot exist as long as country bank notes are convertible into Bank of England notes.

A very considerable advance in the price of commodities bought and sold in one quarter of this kingdom, while there was no such rise in any other, was not supposable; because the holders of the circulating medium current in the spot in which goods were . . . rendered dear, would exchange it for the circulating medium of the part in which they were assumed to be cheap, and would then buy the commodities of the latter place, and transport them to the former, for the sake of the profit on the transaction.

Moreover, the law of one price can be extended from one kingdom to the whole world as long as currencies are convertible.

We may . . . extend our views, and conceive of Europe, and even of the world, as forming one great kingdom, over the whole of which goods pass and repass ... nearly in the same manner in which they spread themselves through this single country. 
However, prices can differ between countries within the limits of the gold points:

But British paper is not exchangeable for the circulating medium of the continent, unless a discount . . . be allowed. Of this fluctuating discount ... the variations in the course of exchange are the measure. (Thornton [1802] 1978, pp. 260-61)

Finally, he argued that under a specie standard, one country alone can affect world (traded) goods prices only to the extent that it has monopoly power in their production. Great Britain may have this power in the short run, but in the long run the existence of substitutes will diminish the power.

\section{Policy Considerations}

Thornton was one of the first to recognize the possibility of a conflict between external and internal policy goals. In the case of an unfavorable balance of trade caused by an exogenous event such as a harvest failure, the central bank could respond to the resulting gold outflow by reducing the money supply, but taking such a course of action might depress domestic activity. Hence, it would be prudent to maintain an adequate gold reserve to permit the bank to increase its loans while losing gold. ${ }^{15}$

\section{John Stuart Mill}

Perhaps the clearest statement of the traditional approach to the gold standard is in J. S. Mill's Principles of Political Economy ([1865] 1961). Much of the subsequent literature is either a refinement of Mill or attempts to verify his theory. In discussing Mill, I focus on three topics: $(a)$ gold as a commodity money; $(b)$ the natural distribution of precious metals and the adjustment mechanism; $(c)$ the distinction between real and nominal disturbances.

\section{Gold as a Commodity Money}

Mill carefully analyzed the economics of commodity money, according to which market forces ensure a determinate money stock and price level.

In the long run, according to Mill, the exchange value of gold-what it will purchase in terms of other goods and services or the inverse of the price level—will be equal to its cost of production- "the cost in labor and expense, at the least productive sources of supply which the then existing demand makes it necessary to work" (Mill [1865] 1961, p. 502). The conformity will be maintained by deviations in gold output in response to variations in the exchange value of gold relative to its cost of production.

However, because the existing stock of gold is large relative to additions to the stock, it takes a long time for full adjustment to take place. 
And hence the effect of all changes in the conditions of production of the precious metals are at first, and continue to be for many years, questions of quantity only, with little reference to cost of production. (P. 503)

Thus, in the short run, the price level is determined by the relationship between the demand for and supply of money, and only in the long run is it determined by cost of production.

Mill then compared a bimetallic standard to a single metallic standard- "There is an obvious convenience in making use of the more costly metal for larger payments and the cheaper one for smaller" (p. 507), but the arrangement only works if the ratio of the two metals is consistent with their relative costs of production. If relative values change, e.g., the value of gold rises relative to silver, this change will cause replacement of gold by silver coins and the melting of gold coins.

Mill therefore preferred a limping standard.

The advantage without the disadvantages of a double standard, seems to be best obtained by those nations with whom one only of the two metals is a legal tender, but the other is also coined (the more costly metal), and allowed to pass for whatever value the market assigns to it. (P. 509)

Finally, Mill, like his predecessors, viewed the substitution of paper money for specie up to the point of convertibility as "a national gain," but beyond that "a form of robbery" (p. 551). Moreover, the social saving from the issue of paper money is transmitted to the rest of the world. The specie displaced through the balance of payments will initially lead to a rise in the world price level, but ultimately to a reduction in gold output. The world price level will then return to normal. ${ }^{16}$

\section{Natural Distribution of Precious Metals and Balance-of-Payments Adjustment Mechanism}

In the long run, each country in the world will have that quantity of money to effect exchange consistent with keeping its value in terms of its cost of production, hence the natural distribution of precious metals across countries is determined by real forces. ${ }^{17}$

Mill then compared the international adjustment mechanism under a barter system with that under a money system. Starting from a state of stable equilibrium where the value of exports equals the value of imports "the process by which things are brought back to this state when they happen to deviate from it, is, at least outwardly, not the same in a barter system and in a money system." Under barter,

a country which wants more imports than its exports will pay for, must offer its exports at a cheaper rate, as the sole means of creating a 
demand for them sufficient to reestablish the equilibrium. When money is used, the country ... takes the additional imports at the same price as before, and as she exports no equivalent, the balance of payments turn against her; the exchange becomes unfavourable, and the difference has to be paid in money. This is in appearance a very distinct operation from the former. (Mill [1865] 1961, pp. 619-20)

However, this difference is only apparent; in both cases prices must adjust to restore equilibrium. In the case of a money economy:

When ... the state of prices is such that the equation of international demand cannot establish itself, the country requiring more imports than can be paid for by exports; it is a sign that the country has more of the precious metals ... than can permanently circulate, and must necessarily part with some of them before the balance can be restored. The currency is accordingly contracted: prices fall, and among the rest, the prices of exportable articles; for which, accordingly, there arises, in foreign countries, a greater demand: while imported commodities have possibly risen in price, from the influx of money into foreign countries, and at all events have not participated in the general fall. (Pp. 620-21)

Thus, through the price-specie-flow mechanism the same results will be achieved as under barter, with the only difference that relative prices adjust as a consequence of changes in the quantity of money induced by specie flows rather than adjust directly. "In international, as in ordinary domestic interchanges, money is to commerce only what oil is to machinery, or railways to locomotion-a contrivance to diminish friction" ( $p$. 622 ).

Mill made a clear distinction between temporary and permanent disturbances to the balance of payments. When a disturbance is temporary, most of the adjustment takes place through variations in the exchange rate, within the gold points. Thus the deficit will be "soon liquidated in commodities, and the account adjusted by means of bills, without the transmission of any bullion" (pp. 617-18). In the case of a permanent disturbance to the balance of payments, the adjustment must be made by "the subtraction of actual money from the circulation of one of the countries" (p. 618).

\section{Distinction Between Real and Nominal Disturbances}

Since the natural distribution of precious metals is determined by real forces, changes in that distribution will only follow from a change in real forces. Thus Mill made a clear distinction between the effects of a real disturbance, such as a remittance from one country to another, and a purely nominal disturbance, such as the discovery of a hoard of treasure.

In the first case, he starts from a state of equilibrium, after the first remittance is 
made in money. This lowers prices in the remitting country, and raises them in the receiving. The natural effect is that more commodities are exported than before, and fewer imported, and that . . . a balance of money will be constantly due from the receiving to the paying country. When the debt thus annually due to the tributary country becomes equal to the annual tribute . . no further transmission of money takes place; the equilibrium of exports and imports will no longer exist, but that of payments will; the exchange will be at par, the two debts will be set off against one another, and the tribute or remittance will be virtually paid in goods.

In addition, the terms of trade will turn against the paying country and in favor of the receiving country. "The paying country will give a higher price for all that it buys from the receiving country, while the latter . . obtains the exportable produce of the tributary country at a lower price" (Mill [1865] 1961, pp. 627-28)

In contrast, a disturbance in the money market changes the world price level with no real effects. Thus the discovery of a hoard of treasure in a country with a purely metallic currency will raise prices there, check exports and encourage imports, leading to a balance-of-payments deficit and diffusion of the new stock of money over the commercial world; consequently the country's price level will revert to its previous level.

\section{John E. Cairnes}

Cairnes in his essays on gold (first published in 1858-60, reprinted in 1873) used the monetary history of the Australian colonies following the gold discoveries of 1851 to test some of the principal conclusions of classical monetary and trade theory. ${ }^{\text {is }}$ In particular, he tested the ability of the quantity theory of money to predict the comparative static effects of the gold discoveries on the money supplies and price levels of the major countries of the world, and the ability of the Hume-RicardoThornton-Mill adjustment mechanism to predict the distribution of precious metals. ${ }^{19}$

Starting with the long-run cost-of-production theory of money, Cairnes argued that "the rate of gold earnings [is] . . the circumstance which, in the final resort, regulates the value of the metal and sets the limit beyond which depreciation cannot permanently pass" (Cairnes [1873] 1965, p. 41); and since gold earnings in Australia increased by 50 percent, i.e., the cost of gold fell by one-half, he expected the price level in Australia to double. The inflation process would spread across the world until either prices doubled or the cost of producing gold rose. Finally, as prices in the rest of the world rose, gold would become a less profitable commodity to produce and export until, in the limit, when the price of Australian imports increased by the amount of the fall in the cost of gold, Australia 
would cease to have a comparative advantage in gold and would divert resources back to agriculture (p. 48).

In 1872, twelve years after writing his essays on gold, Cairnes found, as he had predicted, that $(a)$ exhaustion of the mines and the resulting rising costs of production and $(b)$ rises in the price of imports led to a considerable shift of resources out of gold production and back into agriculture.

Next Cairnes examined the factors that determine the pace of price adjustment across countries. He argued that the rise in prices would be most rapid in countries with the most advanced banking systems-the more developed the system of banking and credit, the smaller the amount of new gold required to effect a given rise in prices. Furthermore, since Australia and California conducted most of their trade with the United States and England, most of the new gold would tend to go first to these countries, and from there it would spread to the continent of Europe and to Asia (pp. 67-68). ${ }^{20}$

In general, Cairnes found the evidence agreeable to his predictionsprices increased most in Australia, followed by price increases in descending order of magnitude in Great Britain and the United States, the Continent, and finally Asia. Moreover, in a postscript, Cairnes reported that $(a)$ world gold production doubled by 1868 and $(b)$ most of the gold ended up in France and India, although much of it passed through England (pp. 160-65).

\section{George J. Goschen}

The clearest statement of the classical position on short-term capital flows in the balance-of-payments adjustment mechanism is in Goschen ([1892] 1978).

Changes in interest rates and short-term capital flows facilitate the balance-of-payments adjustment mechanism since

money will be dear and scarce in the country which owes much to foreign creditors, and plentiful in that which has exported much; and, high interest will be attracting money to that quarter whence specie is flowing out in payment of foreign debts.

[an] adverse balance of trade will . . . render the bills on the country which is most in debt difficult of sale, and tend to compel it to export specie; whereas the high rate of interest, which is generally contemporaneous with a drain . . . of specie, will revive a demand for bills on this same country, and enhance their value in other quarters, for there will be a general desire to procure the means of remitting capital to that market where it commands the highest value. (Goschen [1892] 1978, p. 127)

Thus, 
where a considerable efflux of specie is taking place, the rate of interest will rise in the natural course of things. The abstraction caused by the bullion shipments will of itself tend to raise that rate. (P. 132)

Moreover, a country can finance a temporary balance-of-payments deficit by borrowing abroad. Finally, arbitrage in the securities market will ensure that interest rates for a similar class of bills will be equal between financial centers, account being taken of transportation costs and exchange risks.

If at any time the rate of interest here falls below that which rules on the continent, it is inevitable that the whole mass of these bills will at once be sent to London, and be discounted there at the cheaper rate, so that the proceeds may be remitted in gold to the continent to be invested there in local securities at the supposed higher rate. (P. 138)

\section{Walter Bagehot and the Responsibility of the Bank of England}

The pure gold standard in England-when the money supply consisted in large part of specie, and variations in its amount were determined mainly by the balance of payments-became a managed gold standard in the course of the nineteenth century-when the money supply consisted primarily of convertible notes and deposits, and variations in its amount were determined by operations of the Bank of England conforming to the external constraint of the gold standard. The evolution to a managed gold standard evoked considerable debate in the economic literature. ${ }^{21}$

In the decades after the restoration of convertibility in 1821, British monetary history was punctuated by a series of monetary crises in 1825 , $1836,1838,1847,1859$, and 1866 (see Viner [1937] 1975, pp. 218-20). These crises occurred when the necessary contraction of the money stock consequent upon a specie outflow (an external drain) coincided with a demand by deposit and note holders for specie currency (an internal drain). In such a situation it was difficult for the Bank to maintain convertibility of its notes without resort to special measures. The Bank Charter Act of 1844 was an attempt to rectify the situation by dividing the Bank of England into an Issue Department and a Banking Department. The former was charged with the responsibility of maintaining the gold standard link by following the "currency principle": The note circulation should fluctuate one-for-one with changes in the Bank's holdings of gold. ${ }^{22}$ The latter was to follow the principles of a profit-maximizing banking enterprise, accepting deposits and making discounts.

The arrangement was criticized on two grounds: (1) the currency principle ignored the role of deposits as an increasingly important component of the money stock, ${ }^{23}$ and (2) the Banking Department in operating on a sound commercial-banking basis could not act responsibly as a central bank. In that role, it had to maintain a gold reserve large enough 
to protect the rest of the banking system from the effects of both internal and external specie drains. ${ }^{24}$ This criticism culminated in the 1860 s with the formulation by Walter Bagehot, the influential editor of the Economist, of the "responsibility doctrine" and the establishment of guidelines for a central bank under a gold standard.

In Lombard Street ([1873] 1969), Bagehot clearly set out the conflict between the private concern of the Banking Department to reduce the holding of specie reserves to minimize foregone interest costs and its public concern to hold larger reserves (p. 38).

Bagehot argued for the "responsibility doctrine"-that the Bank of England must fulfill its special obligations as a bankers' bank and as holder of the nation's specie reserves. In consequence, he established clear guidelines for central-bank behavior in times of crisis.

First, in the case of a purely external drain,

the Bank of England requires the steady use of an effectual instrument. That instrument is the elevation of the rate of interest. If the interest of money is raised, it is proved by experience that money does come to Lombard Street, and theory shows it ought to come. (P. 46)

The rise in Bank rate will initially lead to a short-term capital inflow and a gold inflow.

And there is also a slower mercantile operation. The rise in the rate of discount acts immediately on the trade of this country. Prices fall here; in consequence imports are diminished, exports are increased, and, therefore, there is more likelihood of a balance in bullion coming to this country after the rise in the rate than there was before. (P. 47)

Second,

the best way for the Bank . . . to deal with a drain arising from internal discredit is to lend freely. . . . A panic . . . is a species of neuralgia, and according to the rules of science you must not starve it. The holders of the cash reserve must be ready not only to keep it for their own liabilities, but to advance it most freely for the liabilities of others. (Pp. 48, 51)

In brief, the central bank has a responsibility to act as lender-of-lastresort.

Finally, in the case of both an internal and an external drain, the central bank should follow what has come to be known as Bagehot's rule.

We must look first to the foreign drain, and raise the rate of interest as high as may be necessary. Unless you can stop the foreign export, you cannot allay the domestic alarm. The Bank will get poorer and poorer, and its poverty will protect or renew the apprehension. And at the rate of interest so raised, the holders . . . of the final Bank reserve must 
lend freely. Very large loans at very high rates are the best remedy for the worst malady of the money market when a foreign drain is added to a domestic drain. (P. 56)

Bagehot was aware of the limitations to the Bank's control mechanism. The Bank could only temporarily affect market interest rates. The initial effect of an increase in central-bank lending is to lower interest rates, but it also leads to an "increase of trade and increase of prices." The rise of prices and trade leads to an increase in the demand for loanable funds and also to an increase of imports and a decrease in exports. The resultant balance-of-trade deficit leads to a specie outflow and a reduction in reserves, and hence the rate of interest must be raised (pp. 12-14).

In conclusion, Bagehot proposed several remedies for reform. Of key importance, "there should be a clear understanding between the Bank and the public that, since the Bank holds our ultimate banking reserve, they will recognize and act on the obligations which this implies" (p. 70); and the Bank should hold an adequate reserve to be determined by "experience" (p. 304). ${ }^{25}$

Following the publication of Lombard Street, the Bank of England's special position as both lender-of-last-resort and holder of the nation's reserve was recognized, but increasing stress was laid on the Bank's vulnerability in view of London's growing international liabilities (see Sayers 1957). Though Bagehot and other writers urged the Bank to meet the problem by maintaining a larger specie reserve (an approach taken by other countries), the Bank's solution was to alter its discount rate whenever its international reserves were affected, thereby primarily influencing short-term capital movements. The Bank also supplemented the use of Bank rate with other tools of monetary policy, especially open-market operations, and in addition learned to protect its reserves by using special techniques referred to as "gold devices" (see Viner [1937] 1975 , p. 277; Sayers 1936, chap. 3). Thus the ultimate answer to Bagehot's concern was the use "of a powerful bank rate weapon with a 'thin film of gold" "' (Sayers 1951, p. 116).

\section{Appendix B The Neoclassical Economists: Extension of the Traditional Approach}

In this appendix, attention will center on the works of three neoclassical economists-Alfred Marshall, Irving Fisher, and Knut Wicksell-who wrote extensively on the gold standard and whose contribution can be viewed as a refinement or extension of the traditional approach. 


\section{Alfred Marshall}

Marshall's contribution $(1923,1926)$ to the traditional approach can be classified under two headings: the monetary standard and proposals for reform and the balance-of-payments adjustment mechanism.

\section{The Monetary Standard and Proposals for Reform}

For Marshall, the primary purpose of a monetary standard is to ensure price stability:

Violent fluctuations of prices are less distasteful to the heads of business enterprises than a gradual fall of prices. But I believe they are far more injurious both physically and morally to the community at large. (Marshall 1926, p. 20)

Nevertheless, a gold or silver standard may not be the best mechanism to ensure price stability, at least in the long run.

Gold and silver, separately or conjointly, can set good standards of general purchasing power, in regard to obligations and business transactions, which do not range over more than a few years; but obligations which range over long periods, call for standards that are not dependent on the hazards of mining. (Marshall 1923, p. 52)

Marshall admitted that in past years, technical advances in mining precious metals had kept pace with technical advances elsewhere, so the real cost of producing the precious metals had remained constant over long periods of time, which was no accident; but he still believed that

as the arts of life progress . . man must demand a constantly increasing precision from the instruments which he uses, and from money among others: and he is beginning to doubt whether either gold or silver, or even gold and silver combined, give him a sufficiently stable standard of value for the ever widening range of space and time over which his undertakings and contracts extend ... [indeed] gold and silver have had a less stable value, during the history of the world, than has accrued to those staple grains, which have supplied the chief means of supporting life to the great mass of the people in every age. (Pp. 53-54)

Over shorter periods of time, however, gold and silver represent good monetary standards because changes in the stock are small relative to the existing stock (1926, p. 177).

In addition, following the classical tradition, Marshall regarded gold as an inefficient form of money tying up scarce resources. Civilization had advanced sufficiently for an expanded role for convertible paper (p. 137).

Finally, following Mill, he opposed bimetallic schemes based on a fixed ratio of gold to silver on the ground that changes in relative costs of production would lead to continuous shifts towards the lower-cost metal, 
thus producing more instability than reliance on one metal alone (1923, p. 63).

To solve the shortcomings of reliance on precious metals as a monetary standard, Marshall proposed two alternative schemes-symmetallism and a tabular standard.

Under the symmetallic scheme, currency would be exchangeable for a combination of gold and silver bullion bars in fixed proportions.

A gold bar of 100 grammes, together with a silver bar, say, 20 times as heavy, would be exchangeable ... for an amount of the currency which would be calculated and fixed once for all when the scheme was introduced. . . . Anyone who wanted to buy or sell gold or silver alone in exchange for currency could get what he wanted by exchanging gold for silver, or silver for gold, at the market rate. Government fixing its own rates from day to day, so as to keep its reserve of the two metals in about the right proportion, might safely undertake this exchange itself, and then anyone could buy or sell either gold or silver for currency in one operation. (1926, p. 29)

The scheme would provide a better monetary standard than Ricardo's gold-bullion-reserve scheme,

because it causes the value of legal tender money to vary with the mean of the values of both of these metals . . . and because it would be convenient both to those countries which now chiefly use gold and to those which now chiefly use silver. (P. 28).

In contrast, the tabular scheme, similar to that of Fisher (see p. 53 below) would separate the standard of value from the medium of exchange. Under this scheme, long-term contracts would be tied to "an official index number, representing average movements of the prices of important commodities" (1923, p. 36). In addition, he proposed regulation of an inconvertible currency so that "the value of a unit of it is maintained at a fixed level," based on an index number (p. 50).

Finally, Marshall stressed the need for an international currency or else for the international harmonization of monetary policies:

There is a real, though very slow moving, tendency for national interests to overrule provincial interests, and international interests to overrule national, and 1 think the time will come at which it will be thought as unreasonable for any country to regulate its currency without reference to other countries as it will be to have signalling codes at sea which took no account of signalling codes at sea of other countries. (1926, p. 135)

\section{Balance-of-Payments Adjustment Mechanism}

Following Ricardo, Marshall argued that gold flows reflect arbitrage in a widely traded commodity (gold) 
[so] as to bring gold prices at the seaboards of the two countries to equality, allowance being made for carriage. If they are higher in $\mathrm{A}$ than in $B$, there will be a small temporary bounty on exportation from $\mathrm{B}$ to $\mathrm{A}$ corresponding to this difference, which must always be small. Bills drawn in B on A will multiply, and, specie point being reached, gold will go from A to B till prices in B are as high as in A. (Marshall, 1926, p. 170)

However, he questioned why gold has to be the commodity used to settle payments imbalances. Thus in the case of a balance-of-payments deficit

the value of gold, as a means of purchasing foreign commodities by being exported in exchange for them, will rise so much that it will be profitably exported for the purpose: . . . But under these conditions merchants are likely to look around them, and see whether there is not some other thing which the country does not produce herself, and therefore does not habitually export; but which could under the circumstances be marketed profitably abroad. (1923, p. 153)

For example, the balance of payments could be settled by the exportation of lead once "lead point" has been reached. The choice of which commodity is used

depends partly on its portability and partly on the extent of the market which it finds in either country. The power of gold for this purpose is therefore of primary importance between two countries which have a gold currency, for gold has in each a practically unlimited market. (1926, p. 172). ${ }^{26}$

Marshall then discussed the internal adjustment mechanism to an external disturbance such as a gold outflow. The gold outflow would lower the Bank of England's reserves, the Bank would respond by raising its discount rate, and "the result would be a check to speculative investments, a diminished demand for commodities, and a fall of prices" (p. 158). ${ }^{27}$ At the same time, the rise in the discount rate, if not matched by an equal rise in the discount rate abroad, would attract gold from abroad (p. 160).

Finally, he discussed the role of a force that would weaken the traditional adjustment mechanism-the international integration of markets for securities and commodities:

The growing tendency of intercommunication has shown itself in the discount market more than in any other; fluctuations in the price of wheat are being held in check by the growing internationality of the wheat market; but the discount market is becoming international more rapidly even than the wheat market. (Pp. 127-28) 
Thus in Marshall's view, more of the adjustment to balance-of-payments disequilibrium takes place through capital flows than through the arbitrage of traded goods, with less of the burden placed on gold flows.

\section{Irving Fisher}

I focus on three important aspects of Fisher's (1920, [1922] 1965) treatment of the gold standard: his exposition of the operation of a commodity money standard, his discussion of the international adjustment mechanism, and his criticism of the gold standard and advocacy of a "compensated dollar." 25

\section{The Commodity Theory of Money}

Fisher's exposition of the working of a commodity money standard is perhap the most lucid extension of Mill's theory. First Fisher demonstrated how, under a gold standard with unrestricted coining and melting, the price of gold bullion would conform to the price of coin, allowing for seigniorage. Thus, in the case of unrestricted coinage, if the price of gold bullion exceeds that of coin, gold users such as jewellers will melt coin into bullion; in the opposite situation, bullion owners will take bullion to the mint and have it coined. The effect of melting the coin will decrease the stock of gold coins relative to bullion, reducing the value of gold as bullion relative to gold as money, thus lowering the price level and restoring equality between bullion and money. In the opposite case, the effect of minting bullion into coin will restore equilibrium (Fisher [1922] 1965, p. 97).

Next Fisher demonstrated how the world gold stock and the world monetary gold stock are influenced by the production and consumption of gold:

As the stock of bullion and the stock of money influence each other, so the total stock of both is influenced by production and consumption. The production of gold consists of the output of the mines which constantly tends to add to the existing stocks both of bullion and coin. The consumption of gold consists of the use of bullion in the arts.(P.99)

He then made the analogy to a reservoir, "production would be the inflow from the mines, and consumption the outflow to the arts, by destruction and loss" (p. 99). Gold production is regulated by the relationship between "the estimated marginal cost of production" and the purchasing power or exchange value of gold. He assumed that gold mining is an increasing-cost industry. Thus,

gold production will always tend toward an equilibrium in which the marginal cost of production will . . . be equal to the value of the product. . . . If [the] purchasing power of gold is above the cost of 
production in any particular mine, it will pay to work that mine. . . Thus the production of gold increases or decreases with an increase or decrease in the purchasing power of gold. (Pp. 101-3).

And the purchasing power of gold in turn would vary inversely with the prices of other goods.

The consumption of gold "in the arts"-nonmonetary uses of gold-is related to "consumption for monetary purposes"-monetary uses of gold-by a comparison of the purchasing power of gold with the "marginal utility of what is consumed." Thus consumption of gold-the diversion of gold from monetary to nonmonetary uses-will be "stimulated by a fall in the value (purchasing power) of gold, while the production of gold is decreased" (p. 104).

The two forces of production and consumption, operating in opposing directions, regulate the monetary gold stock and hence the price level. In the case of increased gold production due to the discovery of new mines, the increase in production will lead to a filling up of "the currency reservoir," and "a decrease in the purchasing power of money. This process will be checked finally by the increase in consumption. And when production and consumption become equal, an equilibrium will be established" (pp. 108-9).

\section{International Adjustment Mechanism}

Fisher effectively argued that for a small open economy that is part of an international gold standard, as is the case for one state within the United States, the money supply is not an independent variable, but is determined by the need for the domestic price level to conform to foreign price levels. However, he preserved the classical quantity-theory notion of causality between the quantity of money and the price level (see Girton and Roper 1978).

The price level in an outside community is an influence outside the equation of exchange of that community, and operates by affecting its money in circulation and not by directly affecting its price level. The price level outside of New York City, for instance, affects the price level in New York City only via changes in the money in New York City. Within New York City it is the money which influences the price level, and not the price level which influences the money. The price level is effect and not cause. (Fisher [1922] 1965, p. 172)

Following the tradition of Ricardo and Marshall, Fisher argued that the force of arbitrage would tend to produce equality in the prices of traded commodities, but to the extent that international (and interlocal) trade does not bring about uniformity of price levels, ${ }^{29}$ "it will . . p produce an 
adjustment of these levels toward uniformity by regulating ... the distribution of money" (p. 93).

Thus gold flows because it is the most efficient international medium of exchange and because it affects the prices of all commodities.

In ordinary intercourse between nations . . . there will always be a large number of commodities thus acting as outlets and inlets. And since the quantity of money itself affects prices for all sorts of commodities, the regulative effect of international trade applies, not simply to the commodities which enter into that trade, but to all others as well. (P. 93)

\section{Criticisms of the Gold Standard and Proposals for Reform}

Like Marshall, Fisher criticized the basing of the monetary standard on a single commodity-gold or, for that matter, silver-because of instability in supply and demand conditions of the money metal.

The commercial world has become more and more committed to the gold standard through a series of historical events having little if any connection with the fitness of that or any other metal to serve as a stable standard . . . so far as the question of monetary stability is concerned, ... we have hit upon the gold standard by accident. (Fisher [1922] 1965, p. 323)

Instead, in a comparison of the purchasing power of gold with that of a number of other commodities he concluded that "in terms of general purchasing power, gold is no more stable than eggs and considerably less stable than carpets" (Fisher 1920, p. 41). ${ }^{30}$

In addition, Fisher, a number of years later, criticized the gold standard because it allows price-level movements and business fluctuations to be transmitted from one country to another. ${ }^{3 !}$

As a remedy for the inherent instability in the purchasing power of money under the gold standard, Fisher offered his scheme for a compensated dollar: Issue gold certificates backed by gold bullion, but vary the weight of the gold backing per dollar so as to maintain a constant purchasing power of money by tying the weight to an index number- -"to mark up or down the weight of the dollar (that is, to mark down or up the price of gold bullion) in exact proportion to the deviations above or below par of the in dex number of prices" ([1922] 1965, p. 498). This would allow us to "keep the metal gold for the good attributes it has-portability, durability, divisibility, salability — but correct its instability, so that one dollar of it will always buy approximately [a] composite basketful of goods." It would "retain gold as a good medium [of exchange] and yet . . make it into a good standard" (1920, pp. 88-89). 


\section{Knut Wicksell}

Wicksell's views ([1898] 1965) on the gold standard will be discussed under three headings: the commodity theory of money, the international adjustment mechanism, and proposals for reform.

\section{Commodity Theory of Money}

In contrast to Fisher, for Wicksell the stabilizing features of the commodity theory were too slow to be of consequence for price-level movements except in the very long run. Either the underlying mechanism was weak or, by the end of the nineteenth century, institutional developments had neutralized or obscured it. Thus

the newly extracted gold-passes, for the most part, not into circulation, but into the stocks of cash of monetary institutions; and gold for industrial uses is mainly taken either out of these stocks or directly out of imported stocks of uncoined metal. In neither case can it be supposed that there is any direct effect on prices. (Wicksell [1898] 1965, p. 31)

The use of gold purely as a monetary base was utopian.

In such a system the value of money would be directly exposed to the effects of every fortuitous incident on the side of the production of the precious metal and every caprice on the side of its consumption. It would undergo the same violent fluctuations as do the values of most other commodities. (P. 35)

\section{International Adjustment Mechanism}

Wicksell was skeptical of the Hume price-specie-flow mechanismdisturbances affecting one country's price level relative to another's would affect the terms of trade, and the balance of payments would then be corrected by gold flows. Although the explanation was fundamentally correct, he expressed reservations:

It is . . clear that international equilibrium of prices is usually reached far more rapidly and far more directly. The increase in the supply of foreign goods and the diminution in the demand for exports must themselves exert, directly and indirectly, a pressure on domestic prices which is quite independent of any simultaneous movement of precious metals. (Wicksell [1898] 1965, pp. 157-58)

For Wicksell, changes in real income must be brought into the adjustment mechanism.

\section{Proposals for Reform}

Like Fisher, Wicksell was concerned with price stabilization, both nationally and internationally. He favored the use of gold certificates 
backed by a reserve of gold bullion, with each central bank maintaining convertibility and agreeing to accept other central banks' notes and clearing them through an international clearing house (Wicksell [1898] 1965 , pp. 186-87). In addition, the central bank of each nation would stabilize its internal price level by keeping the market rate of interest in line with the "natural rate of interest" following simple criteria: ${ }^{32}$

So long as prices remain unaltered the bank's rate of interest is to remain unaltered. If prices rise, the rate of interest is to be raised; and if prices fall, the rate of interest is to be lowered; and the rate of interest is henceforth to be maintained at its new level until a further movement of prices calls for a further change in one direction or the other.

To achieve international price stability, central banks would need to manipulate their gold stocks cooperatively to keep interest rates in line between nations (p. 192).

\section{Appendix C The Harvard Neoclassical School}

F. W. Taussig of Harvard and his students-Jacob Viner, F. D. Graham, J. H. Williams, and H. D. White-and W. A. Beach (a student of Allyn Young and J. H. Williams) formulated and tested some of the main tenets of the classical Ricardo-Mill theory of the international adjustment mechanism. Taussig's reformulation of the theory and the evidence for Great Britain, the United States, France, Canada, and Argentina in the pre-World War I era are summarized here. In addition the writings of J. W. Angell, a contemporary critic of the Harvard School and a precursor of the modern monetary approach to the balance of payments are examined.

\section{F. W. Taussig}

In an article (1917) and a book ([1927] 1966), Taussig clearly reformulated the traditional approach in a manner suitable for empirical verification and then summarized some of the evidence.

For Taussig, international borrowing was the most important disturbance to the pre-World War I international economy. He analyzed the effects of the transfer of capital on the balance of payments, money supplies, and price levels of both lender and borrower. Several of his studies of British and U.S. experience, beginning with the earliest period he covered, will be reviewed here.

In an examination of the British balance of payments in the period 1853 to 1879 , Taussig found that the adjustment of the merchandise balance of trade to changes in invisibles-both payments and shipping earnings- 
and to capital exports was much more rapid and smooth than classical theory would lead one to expect:

No signs of disturbance are to be observed such as the theoretic analysis previses; and some recurring phenomena are of a kind not contemplated by theory at all. Most noticeable . . . is the circumstance that periods of active lending have been characterized by rising prices rather than by falling prices, and that the export of goods apparently has taken place, not in connection with a cheapening of goods in the lending country, but in spite of the fact that its goods have seemed to be dearer at times of great capital export. (Taussig [1927] 1966, p. 239)

In addition, he found specie movements to be small relative to merchandise movements, a fact to be explained by the sensitivity of the British money supply. Moreover, he found it difficult to separate specie flows consistent with the theory from the more steady series of gold flows into Britain following the gold discoveries in the 1840s and 1850s.

The general lack of conclusive evidence sympathetic to the classical mechanism for the period 1853-79 is reversed for the period 1880-1914. That period is conveniently divided into two parts: $1880-1900$ and 19011914. The first period was characterized by a deficit on merchandise account financed by shipping earnings and income from abroad with no unusual capital exports. The second was dominated by massive capital exports, which were quickly reflected in a decline in the merchandise deficit.

According to Taussig, the change in circumstances offered a good test of the theory. Had the trends before 1900 continued, Britain would have continued to enjoy an improvement in her terms of trade, but the terms of trade turned around after 1900. That phenomenon, he believed, was consistent with classical theory:

That the gross barter terms of trade should vary as they do, becoming more favorable until 1900, thereafter less favorable, is indeed easily in accord with theory. They will naturally fluctuate in the same direction as the balance of payments. . . . More significant . . is the fact that the net barter terms of trade move in the same direction, ... [w]e have argued that when a country has payments to receive for other items than merchandise, the direct and simple exchange of goods for goods is also affected, and is affected to the country's greater advantage. (P. $256)^{33}$

The improvement in the terms of trade raises domestic real income because money incomes rise, while the price of imported commodities falls. Taussig found the evidence that money wages rose until 1900, after which they turned down, consistent with his theory. ${ }^{34}$

However, a continuing puzzle for Taussig was how to separate the influence of equilibrating gold flows from the effects of the steady inflow 
of gold into Britain, the world's principal gold market. Moreover, the puzzle was complicated by the fact that commodity exports and imports

[respond] with surprising promptness to the balance of international payments as a whole. The promptness is surprising because each constituent transaction . . . is purely in terms of money. . . . Yet the recorded transactions between countries show surprisingly lit tle transfer of the only "money" that moves from one to the other-gold. lt is the goods that move, and they seem to move at once; almost as if there were an automatic connection between these financial operations and the commodity exports or imports. That the flow of goods should ensue in time, perhaps even at an early date, is of course to be expected. . . What is puzzling is the rapidity, almost simult aneity, of the commodity movements. The presumable intermediate stage of gold flow and price changes is hard to discern, and certainly is extremely short. (P. 261)

$\mathrm{He}$ also examined a case under the gold standard of U.S. borrowing long-term capital from Great Britain ${ }^{35}$ To the extent that not all of the proceeds of the loan are spent on British goods,

the increase in remittances from London to New York will cause a demand for New York exchange in London. New York exchange will rise in London, sterling exchange will fall in New York. ... The fluctuations in foreign exchange will necessarily be confined within the gold points. (Taussig, 1917, p. 394)

The next step is a gold flow from London to New York once the specie-export point is reached. Elsewhere, Taussig argued that in the case of temporary disturbances, gold rarely flows. Much of the adjustment is taken up by movements in the exchange rate within the gold points that speculators promoted. In addition, in the prewar era, sterling bills acted as a substitute for gold in important money-market centers and were transferred in lieu of gold flows. Finally short-term capital movements acted as a substitute for gold flows. "In the last resort, when all expedients for adjusting and equalizing the payments between nations have been utilized and exhausted, specie will flow in payment of balances" ([1927] 1966, pp. 220-21).

The gold inflow into the United States and the gold outflow from Great Britain then raises and lowers the money supplies of the two countries respectively (1917, p. 394). However, the effects of gold flows on domestic money supplies depend on institutional arrangements in each country. ${ }^{37}$ ln the pre-World War 1 era of fractional reserve banking and convertible fiduciary money

the inflow or outflow of specie . . primarily affects the discount policy of the banks. Their discount policy in turn affects the volume of accommodation which they offer to the borrowing public, and this in turn affects the volume of notes and deposits. ([1927] 1966, p. 201) 
The next step is a "train of consequences familiar to the reader of Ricardo and Mill. Prices will fall in Great Britain and will rise in the United States" (1917, p. 394). Within the United States, prices of domestic goods and exports rise relative to prices of imports, and opposite movements of sectional prices occur in Great Britain. ${ }^{38}$ Finally, because the terms of trade have turned in favor of the United States, her citizens are better off: "Their money incomes have risen, the prices of imported commodities have fallen; as buyers of imported commodities they gain" (p. 395).

The opposite takes place in Great Britain. In the case of the United States after 1879 when it was a net importer of British capital and from 1900 to 1914 when it financed a merchandise surplus with immigrant remittances and other invisibles, Taussig expected to observe gold movements and terms-of-trade effects opposite to those he had observed in the British case.

As in the British case, Taussig ([1927] 1966, p. 299) found it difficult to separate the effects of equilibrating gold flows from primarily domestic gold production and consumption. However, unlike the British case, the terms of trade did not behave according to theory. It was difficult to discern a marked trend, though the net barter terms of trade were slightly less favorable before 1900 than afterwards. This, he stated

is an unexpected result. . . On general principles we should look for terms of trade more unfavorable in the second stage. The excess in the money volume of exports meant . . . that the United States, in meeting the divers additional charges for immigrants' remittances . . . sent out goods having a greater money value than the goods she bought. . . . The case shows an outcome different from that in Great Britain and Canada during the same period. For these countries, the actual course of events proves to be in accord with theoretical prevision. For the United States it does not. (P. 303)

Taussig attempted to account for the poor results for the United States compared to those for Great Britain and Canada by reference to disturbing causes not present in the other countries. Among these were the tariff that made the terms of trade more favorable than otherwise and an exogenous increase in demand by foreigners for U.S. manufactured goods.

Taussig then analyzed effects of a capital transfer under flexible exchange rates, the example relevant for the period 1862-78 when the United States had inconvertible paper money and Great Britain was on the gold standard (1917, p. 386$)$.

The initial effects of U.S. borrowing in London is to reduce the specie premium in New York (i.e., the U.S.-dollar price of gold falls). This reduction leads to a fall in the paper prices of U.S. exports (as well as domestic goods) and a rise in the paper prices of U.S. imports. As a 
consequence, export industries in the United States are discouraged, imports are encouraged. The opposite effects take place in Great Britain. Thus the total volume of commodities bought and sold in the United States increases, as exports are shifted to domestic consumption.

Moreover, real income rises in the United States because holding the money supply constant, nominal income remains unchanged but prices have fallen. U.S. residents gain not only as purchasers of imports (they do under a gold standard as well), but also as purchasers of domestic commodities. In contrast to the gold standard case, the U.S. terms of trade improve not because U.S. residents have larger money incomes and lower prices, but because they have the same money incomes and lower prices. The opposite results occur in Great Britain.

Taussig's analysis may be contrasted with that in Friedman and Schwartz (1963, pp. 84-85), of the effect on the gold premium of U.S. Treasury gold purchases abroad before resumption.

\section{The Evidence}

Taussig's students presented evidence for the classical adjustment mechanism based on detailed examination of the monetary history of a number of countries under the gold standard and under inconvertible paper money. Initially the case studies for Great Britain, the United States, Canada, and France under the gold standard and then for the United States and Argentina under inconvertible paper will be reported.

\section{W. Beach}

In contrast to Taussig, Beach (1935) presented evidence for Great Britain for the period 1881-1913 unfavorable to the classical price-specieflow model. Beach argued that if differences in the levels of commodity prices were to dominate the adjustment mechanism, then gold would be expected to flow

because the price levels of one country do not rise or fall in accordance with the levels in other countries. The movement of gold forces all countries to keep the same pace through the various phases of the business cycle. (Beach 1935, p. 170)

Thus one would expect gold to flow out of a country in the upswing of the business cycle. Also, according to the classical model, one would expect capital exports to move procyclically so that other things equal, an upswing in a creditor country would induce a capital flow to a debtor country, accompanied by a gold outflow, unless offset by increased purchases of the creditor's exports. Yet Beach found that there was a tendency for gold imports to increase during the prosperity stages of business cycles and for exports to grow during depression, both in Great Britain and the United States. 
Beach's explanation of this anomaly relied on several pieces of evidence. First, he observed a high correlation between business conditions and (long-term) capital exports from Great Britain. The volume of new loans, he suggested, was determined primarily by business conditions (pp. 171-73). Second, in the upswing of the business cycle in Great Britain (and the United States), there was an increased internal demand for gold currency. Third, short-term balances (loans) were sensitive to changes in discount rates, more so than domestic business and prices. Hence in the business-cycle upswing, the internal currency drain put pressure on the reserves of the banking system and the Bank of England, which led to a rise in the discount rate, a short-term capital inflow, and, ceteris paribus, a gold inflow. ${ }^{39}$

Thus

cyclical fluctuations in the movement of specie might easily be controlled by the movements of these balances. This explanation for the cyclical movements of gold found for England and the United States seems more adequate than the explanation based upon price level differences. (P. 180)

\section{Jacob Viner}

Viner (1924) tested the classical balance-of-payments adjustment mechanism for Canada during the period 1900-1913. ${ }^{40}$ During that period, the great disturbing factor was the inflow of foreign capital into Canada. The adjustment to be explained was the "process whereby the Canadian borrowings, negotiated in terms of money, entered Canada in the form of goods and not in gold" (Viner 1924, p. 145).

The mechanism to be tested was that of J. S. Mill. The capital inflow initially would raise the price of foreign exchange to the gold export point. This would then be followed by a gold flow from the lending to the borrowing country. Prices would rise in the borrowing country and fall in the lending country, leading to a change in imports and exports, with the borrowing country experiencing an unfavorable balance of trade and the lending country, a favorable balance. Once the unfavorable balance of the borrowing country equaled the rate of borrowing, the exchanges would return to parity, gold movements would cease, and relative prices in the two countries would stabilize at their new levels.

First, examining the effects of changes in the exchange rate within the gold points, Viner argued that since transportation and insurance costs were very low between Montreal and New York, the gold points were so narrow that changes in the exchange rate were not likely to have much effect on the balance of trade (p. 155).

Second, Viner found evidence that gold flows were highest in the years when Canadian borrowing was most in excess of Canadian loans to others 
(p. 160). At this point, Viner digressed on the role of gold in the Canadian financial system. Before World War I, gold did not circulate as hand-tohand currency but did act as a reserve asset for the chartered banks. (Canada did not have a central bank in this period.) ${ }^{41}$ The Canadian monetary base consisted of a fixed issue of government fiduciary notesDominion notes and gold reserves, largely maintained as "outside reserves" on call in New York or London, or as balances with commercial banks in those centers. According to Viner, changes in outside reserves in New York acted in a manner similar to gold flows in the classical balanceof-payments adjustment mechanism. Thus the transfer of foreign capital from London to Canada usually passed through the New York money market, raising outside reserves of Canadian banks. Then on the basis of the increased outside reserves, Canadian banks would increase their deposits (pp. 177-79).

Third, the increase in the Canadian money supply would produce a rise in the Canadian price level (relative to the rest of the world) in accordance with the classical theory $y^{42}$ and a rise in sectional price levels. The initial effect would be on the prices of domestic goods and not on the prices of imports, which for a small open economy such as Canada are determined abroad. Some substitution away from domestic goods towards imports would follow as would also a rise in the price of exports (to the extent Canada had monopoly power in their production), leading to a reduction in exports. ${ }^{43}$

The evidence generally confirms these predictions: between 1900 and 1913 indexes of the prices of imports increased least, followed by the prices of exports, while domestic prices increased the most. Moreover, a beginning-of-period weighted index of the price of exports declined relative to an unweighted index, suggesting that commodities shifted from the export to either the domestic or import category. In addition, the ratio of domestic-goods prices to the wholesale price index increased more in Canada than in the United States. ${ }^{44}$ Finally a decline in exports and a rise in imports completed the case for Viner in favor of the classical adjustment mechanism. ${ }^{45}$

This theory has been verified inductively for Canada during the period 1900 to 1913. [Moreover,] a corollary of this reasoning [is] that during a period of international borrowings the terms of international exchange shift in favor of the borrowing country and against the lending country. ... Adequate inductive verification of this proposition is supplied by the demonstration already made that export prices rose relative to import prices. (P. 295)

\section{Harry D. White}

White (1933) examined the French evidence for the classical pricespecie-flow explanation of the effects of capital exports. Like Britain, 
France in the four decades before World War I lent large sums abroad, and as in the British case, for contemporary economists, the income from foreign investment permitted a persistent merchandise-trade deficit. In a careful reconstruction of the French balance-of-payments accounts, White demonstrated that the income from foreign investment over the 1880-1913 period was no greater than the total export of capital for the same period. Moreover he found, contrary to the official figures, that in twelve out of the thirty-four years surveyed, France had a surplus on merchandise account; and the years when the French accounts showed a deficit on merchandise trade it was paid for not by revenue from French foreign investment but by foreign-tourist expenditures in France (White 1933, p. 301).

White then attempted to determine, as Taussig did for Great Britain, the adjustment mechanism by which the net capital export affected the balance of trade:

Tho the totals of capital exports and net revenue from foreign investment over the period as a whole were not far apart, for any one year during most of the period they differed considerably, thereby raising the question of the mechanism for adjustment of the disequilibrium caused by changes in the volume of capital exports. (P. 302)

First, he found that in France's trade with gold standard countries, exchange-rate movements had a negligible effect on merchandise movements, but in the case of a number of countries not on the gold standard, from which France obtained one quarter of her imports, fluctuations in the exchange rate made a significant difference to French importers.

Second, he concluded that in the French case, only a small portion of the sums loaned abroad were spent on French exports.

Third, the movements of sectional price changes and of the volume of merchandise trade revealed a relationship in accordance with the classical sequence. Relative increases in import prices were accompanied by a decline in physical quantities and vice versa. The changes continued until there was a rough approximation between changes in the values of merchandise balances and capital exports. ${ }^{46}$

Fourth, he could find no evidence of the linkage of gold flows to the reserves of the Bank of France and thence to the domestic money supply. According to White, the Bank of France would raise the discount rate only to offset a large gold outflow, but not to influence domestic economic activity. Moreover France's large gold reserves relative to other major gold standard countries enabled it to follow such a passive discount-rate policy.

Fifth, White argued that it was possible that there existed a direct link between gold flows and price-level movements because such a large fraction of the French money supply consisted of gold currency, but 
no clear evidence on . . . the relationship of the quantity of money in circulation to prices is revealed by the comparison between the fluctuations in the quantity of specie and notes outside the Bank of France and the movement of prices. Moreover, even if such a relationship were revealed, the absence of correlation between the annual movements of capital and specie renders dubious the interpretation that changes in sectional price levels were induced by capital movements. (P. 304)

Finally, the mixed evidence leads him to conclude that

the specie-flow-specie mechanism is doubtless one of the forces, but there seems to be no justification for assuming that it is the sole or even the dominant means of adjustment. . . The neoclassical theory is not the complete explanation. The theory fails in that it explains what happens only under certain given conditions seldom found. It expounds a sequence of changes which undisturbed would in time bring about adjustment, but which seldom, if ever, operates unchecked by the frictions and rapid changes characteristic of modern economic conditions. By ignoring some of these forces and minimizing others, the neoclassical exposition exaggerates the effectiveness of gold flows and sectional price changes as a means for establishing equilibrium in international accounts. (P. 306)

\section{Frank D. Graham}

Graham tested Taussig's (1917) theory of the adjustment mechanism under depreciated paper. In the period 1862 to 1878 , when the United States was on an inconvertible paper standard-the greenback standard-while her principal trading partner, Great Britain, was on a gold standard, the premium on gold was a close proxy for the dollar-pound exchange rate ${ }^{47}$ Graham analyzed the effects of British capital flows-the major source of disturbance during this period to the balance of payments, and hence the exchange rate.

The period can conveniently be divided into two episodes: 1863 to 1873 , a period of heavy and continuous borrowing from London, and 1874 to 1878 , a period when the borrowing dropped off.

According to Taussig's theory, one would expect the period of heavy borrowing to be associated with a deficit in the balance of trade and the period of cessation with a reversal in the balance of trade. Graham's evidence showed a large annual excess of commodity imports over exports in the period of heavy borrowing, the opposite in the period of cessation (Graham 1922, pp. 231-34).

Also, according to Taussig's theory, one would expect, ceteris paribus, the period of heavy borrowing to be associated with a decline in the exchange rate (the premium on gold), while the period of cessation to be associated with a rise in the exchange rate. Graham found the evidence corroborated this prediction. In comparing the price of gold with an index 
number of general commodity prices, he found the quarterly average price of gold to be lower than the general price level from April 1865 through June 1876, while from July 1876 to the end of the period it was higher, with the price of gold rising relative to the overall price level after 1874.

Next, according to Taussig, one would observe the following effects on sectional prices: in the first period, low paper prices of exports, gradually declining paper prices of imports, and relatively high paper prices of domestic commodities; in the second period, a gradual reversal towards higher paper prices of exports, gradually rising paper prices of imports, and relatively low prices of domestic goods. A comparison of the arithmetic means of the three different groups of commodities between the two periods provided evidence consistent with the theory.

Finally, one would observe different effects on money wages (as a measure of relative prosperity) in the two periods: in the first period declining wages in the export industries relative to the domestic-goods industry, as resources are diverted from it in the face of falling prices; the opposite movement in the second period. Again, using Mitchell's wage data and classifying U.S. industries into domestic and export industries, Graham found the evidence consistent with the theory (pp. 267-70).

At the same time as these effects occurred in the United States, opposite ones would occur in Great Britain, although the fluctuations in the U.S. dollar would have only limited effects on British prices since Great Britain was on a gold basis and movements of the dollar would only affect a portion of her trade. ${ }^{48}$ Again Graham found the evidence consistent with the theory.

\section{John H. Williams}

Williams (1920) tested for Argentina Taussig's theory of the adjustment mechanism under depreciated paper but unlike Graham found the evidence too inconclusive to be of more than limited support to the theory. First, according to Taussig's theory, a rising premium on gold would stimulate exports. "It does so by virtue of the fact that export prices rise more rapidly than costs, creating an extra profit or bounty for the producing and exporting classes" (Williams 1920, p. 233). Williams presented evidence indicating a rise in the price of exports concomitant with a rising premium on gold in the period 1885 to 1891 . However, according to the theory, the value of exports ought to rise-but it did not. This result Williams attributed to the presence of other forces such as "the character of the Argentine exports ... agricultural and grazing products ... [which are] extremely susceptible to vagaries of climate" and the fact that "though [the] quantity of exports increased, the greater quantity was sold for a lower gold price per unit" (p. 234). 
Second, according to Taussig's theory, a rising gold premium should reduce the value of imports, which the evidence confirmed.

We find first of all that the diminution of value of imports asserted by theory . . . did occur: that, in fact, the diminution was very marked. ... On comparing the course of imports with the gold premium, ... there was in every year an inverse relation between imports and the premium on gold. (P. 253)

In sum, the evidence marshalled by the Harvard school in favor of the classical adjustment mechanism is mixed. Overall price levels adjust in accordance with the theory, but sectional price adjustment in accordance with the theory is limited. Little support was found for the role of gold flows, the money supply, and discount rates in the mechanism. A common finding was that the commodity trade balance adjusted rapidly to the external disturbance of capital flows, more rapidly than would be expected by a theory postulating links from price-level differences to gold flows, to changes in money supplies, to changes in sectional price levels, and then adjustment of the commodity trade balance. Explanations given by the school for the rapidity of adjustment-with no supporting evidence-included the growing integration of goods and securities markets, the role of income effects, and the sensitivity of the money-supply process.

\section{J. W. Angell}

Angell ([1925] 1965), a student of Taussig's, had a distinctly different interpretation of the international adjustment mechanism under the preWorld War I gold standard. Angell focused on the relationship between individual commodity prices and national price levels.

First, he argued that the classical division of the overall price level into export, import, and domestic-goods prices was "extremely misleading and may lead to erroneous conclusions." The distinction he preferred was between international or traded commodities and domestic or nontraded commodities, with the dividing line between the two types of commodities to be determined empirically:

Any movable article whatsoever may enter international trade. . . The first requisite for movement is that the money prices receivable, translated through a common measure, shall be higher in one country than in the other; the second, that the difference shall at least cover costs of transportation of all sorts, including tariff[s] (Angell [1925] 1965, pp. 375-76)

He cited evidence for equality in the world prices of traded goods (staple commodities) at one extreme, and at the other extreme, no international competition and hence no reason for price equalization of nontraded 
goods, with an in-between third category-partially traded goods. Arbitrage would ensure equality for traded-goods prices but arbitrage may not take place for many commodities because of: $(a)$ "lack of accurate information, in each market," $(b)$ "lack of sufficient initiative and enterprise, on the part of the manufacturers and dealers, to take advantage of the discrepancy," $(c)$ "selling in a new market requires the prior erection of trade connections," (d) monopoly power (pp. 379-80).

Second, Angell discussed evidence showing long-run similarity of national price-level movements between countries on the same metallic standard. He defined national price structures as

a series of solar systems, which maintain a fairly constant relationship in their movements through space. But the component parts of the system-individual prices-are in a state of ceaseless change relative to the elements in both their own and other systems. (P. 390)

However, he argued that the similarity of movement of national price levels coupled with the tendency to price equalization of internationally traded goods suggests that domestic (nontraded-goods) prices conform to the pattern set by traded-goods prices. Further, since the process of substitution between domestic and traded goods is a relatively weak one, the key mechanism that keeps prices levels in line is the

classical price specie flow analysis. . . No other type of explanation can adequately account for the known facts. Prices in different countries do not move together, over long periods of time, by sheer accident. There must evidently be some connecting link between them. But the influence exerted by international prices alone, on the various national price structures, is not great enough to provide this link. It is necessary to discover some condition or element that is capable of affecting the totality of prices indiscriminately, and fairly rapidly. This element is found in the mechanism by which the balance of international payments is kept in equilibrium. (P. 393)

Angell offered his own version of the price-specie-flow mechanism. $\mathrm{He}$ downplayed the role of actual gold flows in the mechanism, arguing that

neither the magnitudes nor the directions of the international flow of gold are adequate to explain those close and comparatively rapid adjustments of payment disequilibria, and of price relationships, which were witnessed before the war. (P. 400)

\section{Moreover,}

the character of modern banking [will not] permit the assumption of any very high degree of intimacy to the connection between a country's metallic stock and its price level. Finally, gold is among the least sensitive of the media of international payments, one of the slowest to move. (Pp. 400-401) 
His own version of the mechanism relies on the importance of foreign bills of exchange which act as a substitute for gold. Temporary disequilibria will be offset by movements in the exchange rate. If that proves inadequate, gold will flow, prompting a change in discount rates. Finally, if the disturbance is more than temporary, then

an alteration will take place in the underlying conditions that govern the general course of international exchange itself. The volume of purchasing power in circulation in the creditor country will be built up, in consequence of the increase in the banks' holdings of bills. In the other country it will be reduced, through the decline there in bill holdings. These changes, in turn, will operate upon the corresponding general price levels. The latter effect is often, though not always, strengthened by alterations in the discount rates. The movements in prices will then influence the commodity balance of trade . . . and will continue to do so until the change in the commodity trade has become great enough to offset and correct the original disturbance in the balance of international payments. (P. 413)

\section{Appendix D Interwar Critics}

With the outbreak of war in 1914 and Britain's suspension of convertibility, the classical gold standard expired. The gold-exchange standard existed briefly from 1925 to 1931 , after which the problem of international monetary reform and the creation of a more viable international monetary system took center stage.

The traditional approach to the gold standard was subjected to extensive reinterpretation and criticism, much of it derived from concern over the monetary instability of the interwar period. The reinterpretation of the gold standard began with the Cunliffe report ([1918] 1979) which succinctly restated the stylized facts of the operation of the pre-1914 gold standard and appealed for a return to the old order. Another view (Brown, Smit) of the prewar gold standard stressed that it was successful because it was a managed standard-managed by London. Followers of this institutional approach then documented all the many respects in which the structure of the British money, gold and commodity markets"pax Britannica"-and the astute management of the Bank of England made the system work. The key implication of the approach was that a successful gold standard could be restored if a similar institutional milieu could be re-created. A related approach (Cassel) argued that the gold standard worked well for England, and possibly for several other major countries, but not for the rest of the world. Moreover, the fact that it worked so well for England was largely an accident of history (Viner). 
A recurrent theme in the interwar literature was the inherent policy conflict between internal and external stability under the gold standard fixed-exchange-rate system. According to this view (Keynes), the prewar gold standard worked because nations were willing to subsume domestic economic objectives to the maintenance of gold convertibility; but in the postwar period, a return to the harsh discipline of the prewar gold standard would be disastrous. This approach proposed the creation of a supernational monetary agency or similar means to ensure international harmonization of economic policy.

The final theme in the literature was the expression of doubt about the stylized facts of how the gold standard worked. Returning to the anomalies between fact and theory discussed by the Harvard school, the critics (Whale) argued that perhaps the traditional approach itself was incorrect.

The views of writers identified with each of the foregoing themes are summarized below.

\section{The Stylized Facts}

In the interwar period, a persistent thread in the literature was a view of the prewar gold standard as the ideal monetary standard. A classic statement of this view appeared in the Cunliffe report, but it was repeated by others including R. G. Hawtrey, T. E. Gregory, and the Interim Report of the Gold Delegation of the Financial Committee of the League of Nations ([1931] 1979).

The Cunliffe report ([1918] 1979) to Parliament succinctly presented what seemed to be the salient features of the operation of the prewar gold standard in Great Britain and a series of proposals for a quick return to gold.$^{49}$

As the report documented, the money-supply process before the war was based on the Bank Charter Act of 1844. Apart from a fixed fiduciary issue, hand-to-hand currency consisted entirely of gold and subsidiary coins or of gold certificates. Gold was freely coined and there were no restrictions on the import or export of gold, so changes in the monetary base, aside from movements of gold to and from the arts, were determined by inflows from abroad and outflows. In addition, upon this base of a fixed fiduciary issue and gold and gold-backed currency rested an extensive system of checkable bank deposits, so that the pre-World War I British money supply consisted mainly of deposits.

Second, the report described the operation of the balance-of-payments adjustment mechanism. A disturbance to the balance of payments led to a gold flow and a corresponding change in the money supply. Thus, e.g., when the balance of trade was unfavorable and the exchanges adverse, it became profitable to export gold, and the would-be exporter bought the gold from the Bank of England. The Banking Department in turn 
obtained gold from the Issue Department in exchange for notes from its reserve, with the result that liabilities to depositors and the reserve were reduced by an equal amount, and the ratio of reserves to liabilities declined ${ }^{50}$ The next step was a rise in the discount rate:

If the process was repeated sufficiently often to reduce the ratio in a degree considered dangerous, the Bank raised its rate of discount. The raising of the discount rate had the immediate effect of retaining money here which would otherwise have been remitted abroad and of attracting remittances from abroad to take advantage of the higher rate, thus checking the outflow of gold and even reversing the stream. (Cunliffe report [1918] 1979, par. 4)

Thus raising Bank rate by inducing a short-term capital inflow would be sufficient to stem a temporary balance-of-payments deficit. However, in the case of a permanent disturbance, the discount-rate rise would additionally reduce domestic credit.

This description of the operation of Bank rate to facilitate the adjustment mechanism has often been referred to as the rules of the game. ${ }^{51}$ According to Nurkse:

Whenever gold flowed in, the central bank was expected to increase the national currency supply not only through the purchase of that gold but also through the acquisition of additional domestic assets; and, similarly, when gold flowed out, the central bank was supposed to contract its domestic assets also. . . . The chief methods to be used for changing the volume of domestic central bank assets in accordance with this principle were changes in the discount rate, designed to make borrowing from the central bank either more or less attractive, and purchases or sales of securities in the open market on the central bank's own initiative. (Nurkse [1944] 1978, pp. 66-67)

Moreover, the gold standard also provided an automatic mechanism to offset an internal disturbance:

When . . credit at home threatened to become duly expanded, the old currency system tended to restrain the expansion and to prevent the consequent rise in domestic prices which ultimately causes such a drain. The expansion of credit, by forcing up prices, involves an increased demand for legal tender currency both from the banks in order to maintain their normal proportion of cash to liabilities and from the general public for the payment of wages and for retail transactions. In this case also the demand for such currency fell upon the reserve of the Bank of England, and the Bank was thereupon obliged to raise its rate of discount in order to prevent the fall in the proportion of that reserve to its liabilities. The same chain of consequences ... . described [above] followed and speculative trade activity was similarly restrained. (Cunliffe report [1918] 1979, par. 6) 
Thus,

there was therefore an automatic machinery by which the volume of purchasing power in this country was continuously adjusted to world prices of commodities in general. . . Under these arrangements . . . [the] country was provided with a complete and effective gold standard. The essence of such a standard is that notes must always stand at absolute parity with gold coins of equivalent face value, and that both notes and gold coins stand at absolute parity with gold bullion. When these conditions are fulfilled, the foreign exchange rates with all countries possessing an effective gold standard are maintained at or within the gold specie points. (Pars. 6-7)

The committee recommended a restoration of the gold standard "without delay" (par. 15), to be achieved by the cessation of government borrowings and the reduction of Bank of England note issue. In addition, the committee recommended allowing the free external movement of gold and the use of Bank rate to check outflows and inflows. However, following Ricardo's "Proposal for a Secure Currency," it recommended against the use of gold coins for domestic circulation and in favor of use of all the nation's gold to be held by the Bank of England as backing for the nation's monetary base-a gold-bullion standard. Most of the proposals were adopted when Britain returned to gold in 1925 .

Hawtrey (1935) summarized and expanded upon the stylized facts of the Cunliffe report. He documented the domestic aspects of a gold standard. A gold-coin standard with free coinage and free export and import serves as a device to provide a limit on the supply of money, but the authorities must maintain the quality of the coin. Thus,

the essence of the gold standard is that the price of gold, the value of gold in monetary units, is fixed by law and this determines the wealth value of the monetary unit itself. The use of gold coin . . . provides a fairly close approximation to this ideal. (Hawtrey 1935, p. 20)

A central bank acting as a bankers' bank by holding a pool of gold reserves can reduce the foregone interest cost on commercial banks' holdings of gold coins to maintain convertibility of their liabilities. However, since commercial banks keep their reserves with a central bank, it must accept the responsibility of acting as a lender-of-last-resort.

For the banks and the public do not trouble themselves about the interchangeability of gold and credit. That is the affair of the Central Bank alone. Anyone can sell the Central Bank as much gold as he likes and can procure from it as much gold as he chooses to pay for. The Central Bank is in the gold market as both buyer and seller in unlimited quantities at a fixed price. (P. 24)

The central bank has the power to control the domestic money supply by using its principal tool-its discount rate. By raising the rate, the 
central bank can check lending by "improvident banks" and by lowering the rate it can stimulate lending.

Hawtrey then described the mechanism by which a change in Bank rate operates.

The power of the central bank over the wealth value of the monetary unit ultimately depends on the deterrent effect of a high Bank rate upon the borrowing operations of the customers of the banks. Bank rate is essentially a short term rate of interest. . . . It is the borrowing of money for the purchase of goods that is likely to respond most promptly to a restriction or relaxation of credit, because a trader who wishes to reduce his indebtedness in respect of goods held in stock can readily do so by postponing or reducing his purchases. When traders are tending generally to do this, the effect is immediately felt by the producers of the goods in decreased orders. . . .

... The installation of capital is usually financed by the raising of funds from the long-term investment market, but short-term borrowing is often resorted to in anticipation of the raising of funds from that source or for the purchase and holding of securities. If Bank rate is raised, the holding of capital assets with money temporarily borrowed is discouraged. But the effect on productive activity will be relatively slow, for the installation of capital is a prolonged process, and any such project is likely to be preceded by a long preliminary period of preparation. (Pp. 25-26)

Thus, changes in Bank rate have their primary impact on the holding of inventories.

Hawtrey also discussed international aspects of a gold standard. The commitment by a number of countries to fix the prices of their currencies in terms of gold establishes a fixed-exchange-rate system. The prices in any one currency of gold in different places cannot differ by more than the cost of transporting gold between the different places-arbitrage in the gold market will ensure that outcome. To maintain convertibility of the currency - the primary responsibility of a central bank-an adequate gold reserve is essential. The threat of a loss of gold is more serious than a possible gain, since in the former case the country may be forced to leave the gold standard before the necessary adjustment can take place; in the latter case, although the central bank may temporarily lose control of the market, the stimulus to lending will eventually lead to a reversal of a gold inflow.

Finally, Hawtrey, like Keynes (see below, p. 79) saw an analogy between the operation of a clearing system between banks within one country and a clearing system of central banks under the gold standard.

In his analysis of the balance-of-payments adjustment mechanism following a monetary disturbance, Hawtrey incorporated elements of both the classical adjustment mechanism and the role of income changes. An increase in bank lending in an open economy by stimulating demand will 
ultimately lead to an increase in production and real income, assuming less than full employment, but will initially lead to an increase in sales and reduction in inventories. Merchants and dealers will therefore seek to replenish their stocks. Those dealing in home-produced goods will do so partly by ordering fresh supplies from producers and partly by diverting to the home market goods that might have been sold abroad, while those dealing in foreign-produced goods will order fresh supplies from abroad. The diversion of production from exports and the increase in imports will create an adverse balance of payments and a gold outflow. The process continues until a new higher equilibrium level of income is reached with a lower than initial balance-of-payments deficit.

Once full employment is reached, the increased spending will affect prices. However, the prices of traded goods cannot be fully raised.

These, which may conveniently be called "foreign trade products" comprise not only actual imports and exports but all importable and exportable goods. The prices of foreign trade products are governed by prices in world markets and are fixed in gold. The demand for them will expand as the consumers' income expands, and as the demand expands the loss of gold grows greater and greater. (Hawtrey 1935, p. 41)

In addition, some of the increased income will be diverted to the purchase of foreign securities which will worsen the current-account balance. The process can be arrested and the deficit reduced by an increase in the discount rate-quickly offsetting the capital inflow and ultimately reducing the rise in income. However, "the contraction of the consumers' income is the only substantial corrective" to the balance-of-payments deficit (p. 43).

For Gregory ([1932] 1979), like Hawtrey, the essence of the gold standard is convertibility of national currency into a fixed weight of gold. One of the great advantages of the gold standard therefore is

that . . it eliminates fluctuating rates of exchange ... [that] international trade and investment can be conducted without any fear that the sums risked in a particular trade or investment transaction will not be recovered ... owing to changes in the relative exchange values of different moneys at the date of payment. (Gregory [1932] 1979, p. 9) ${ }^{52}$

In addition, he related the development of the international gold standard in the second half of the nineteenth century to the growth of international trade and investment in that period, and stressed the role

played by gold movements in the establishment of the conditions necessary to secure equilibrium in the international balance of payments of the various countries upon the gold standard. . .

What the international gold standard does . . . is to force prices and incomes in different trading areas into such a relationship that the 
balance of payments can be adjusted without gold flows in either direction. . . . The international gold standard creates, not a common price level but an integrated price-and-income structure. (Pp. 11, 14-15)

The gold standard can operate successfully in the context of modern banking systems and central banks (provided sterilization activity is not undertaken) and of tariffs, capital flows, and transfers.

\section{The Role of London}

An important theme in the literature of the gold standard, developed in the interwar period, was that the gold standard was successful primarily because it was a sterling standard ${ }^{53}$ Perhaps the most succinct statement of the position is in Smit (1934), although a similar viewpoint is expressed in Brown (1940).

According to Smit, by 1914 ,

all the leading money and trade centers in the world were interconnected in a triangular fashion through London, although smaller patterns, directly centered around Paris, Berlin and New York, were woven into the main pattern of the picture. (Smit 1934, p. 53)

ln the prewar world, sterling balances instead of gold were increasingly used by foreign financial institutions to settle international payments:

The most important key to the world's foreign exchange markets lay in the sterling balances of foreign bankers kept in London. . . . London acted as one bank for a customer-neighborhood of bankers that comprised not only the small British island but the whole world. . . The pound, which was internationally wanted for settling commercial and capital indebtedness with the British lsles, became more and more, as a consequence of the world-wide demand that it commanded, a conventional credit counter for settling indebtedness among all countries. (P. 54)

The primary financial interconnection between countries centered on the London discount market because much of the world's foreign trade was financed by sterling bills. ${ }^{54}$

The Bank of England by its discount rate and open-market operations was able to exercise considerable influence over this market. Thus

the extraordinary effectiveness of the English official bank rate in influencing foreign exchange rates and international gold movements before the war cannot be explained unless one sees the integration that had taken place in the world credit structure (P. 55)

ln addition, the spread of the gold standard and integration of the international credit system were closely intertwined as "the legal guarantees of the gold standard limited the risk factor of foreign exchange 
fluctuations and inspired confidence" and "London possessed the world's central gold market. ... The possession of sterling balances was the surest means of getting gold when wanted" (p. 56).

Finally, Smit argued that at the same time as the world moved towards a sterling standard, there was growing internationalization of commodity prices centered in British commodity exchanges. A key consequence of international integration of both commodity and money markets was that the traditional explanation of how the prewar gold standard operated placed too much emphasis on "the existence of different national monetary systems, and the quantitative relations between the separate national money and credit systems and domestic price levels" (p. 55).

Even before World War I, Keynes ([1913] 1971) had noted the unique role of London in the operation of the gold standard. By World War I, England had developed a sound currency and, aided by the effective use of Bank rate, required only a small gold reserve to maintain convertibility in the face of external shocks. However, according to Keynes, most other countries were not as successful in staying on the gold standard. One key difference between Britain and other countries was that she was a net creditor in the international short-loan market, whereas most other countries were debtors.

In the former case, which is that of Great Britain, it is a question of reducing the amount lent; in the latter case, it is a question of increasing the amount borrowed. A machinery which is adapted for action of the first kind may be ill-suited for action of the second. Partly as a consequence of this, partly as a consequence of the peculiar organization of the London money market, the "bank rate" policy for regulating the outflow of gold has been admirably successful in this country, and yet cannot stand elsewhere unaided by other devices. (Keynes [1913] 1971, p. 13)

Most other countries in adopting the gold standard used gold as a medium of exchange but were unable to use the discount rate as an effective method to preserve the standard because, in addition to not being net international lenders, they had not established the elaborate financial network of the London money market.

Consequently other countries used other mechanisms to supplement their inadequacies: they held large gold reserves "so that a substantial drain ... may be faced with equanimity"; they partially suspended payment in gold; and they kept "foreign credits and bills . . . which can be drawn upon when necessary"(p. 14).

Most countries (especially less-developed ones) tended to rely on the last method because it economized on the foregone interest cost of holding gold reserves. ${ }^{55}$ Thus the gold-exchange standard evolved

out of the discovery that, so long as gold is available for payments of international indebtedness at an approximately constant rate in terms 
of the national currency, it is a matter of comparative indifference whether it actually forms the national currency. . . . The gold exchange standard may be said to exist when gold does not circulate in a country to an appreciable extent, when the local currency is not necessarily redeemable in gold, but when the government or central bank makes arrangements for the provision of foreign remittances in gold at a fixed maximum rate in terms of the local currency, the reserves necessary to provide those remittances being kept to a considerable extent abroad. (P. 21)

Cassel (1935) went even further than Keynes, arguing that the gold standard was an international standard neither in the pre- nor the postWorld War I periods. It was only a British standard. He argued that the automatic balance-of-payments adjustment mechanism of price levels adjusting to gold flows never in fact worked that way - that central banks for the sake of security maintained larger reserves than legally required, and therefore exports and imports of gold did not necessarily influence the domestic money supply or the price level.

The gold supply of a country exercised such an influence only via the policy of the central bank and its regulation of the market by means of its rate of discount and its open market operations. Thus the currency necessarily became a "managed currency" whose value depended entirely on the policy of the central bank. (Cassel 1935, p. 3)

In addition, capital flows hindered the automatic functioning of the international gold standard:

A country normally exporting capital could compensate for a loss of gold simply by a reduction of its lending; and a country normally importing capital could compensate for a loss of gold by borrowing more. Thus it was possible to prevent gold imports or exports from having any influence on the price level of the country. (Pp. 3-4)

Finally, the international gold standard did not guarantee a natural distribution of gold:

Creditor countries were in a position to accumulate, if they chose to do so, disproportionate gold stocks without using them for any other purpose than for exercising political influence or merely for satisfying a national pride in the possession of gold. Debtor countries could provide gold reserves by increasing their foreign indebtedness. . . The size of these reserves had very little to do with the balance of trade of the country. Nor did gold imports and exports have any distinct relation to changes in the balance of trade. (P. 4)

That the international gold standard functioned so well before World War I

can only be explained by the basic position that the pound sterling held in this system. Indeed, the pre-war gold standard system may not 
inadequately be described as a sterling bloc held together by London's position as the world's financial clearing center and by the service of the pound sterling as a generally recognized means for international payments. (Pp. 4-5).

Next, in Cassell's view, the international gold standard was fundamentally defective because it was based on the tacit assumption that the purchasing power of gold would be stable and hence that maintenance of a fixed gold parity guaranteed stability in the purchasing power of a country's currency. According to Cassel,

the gold standard ... [suffered] from an inherent and irreparable instability. This instability results partly from the instability of the value of gold itself, and partly from the insecurity of the redemption in gold of gold-standard currencies. (P. 6)

On the first score, he presented evidence of considerable variability in the value of gold for the period 1850 to 1910 , based on the Sauerbeck wholesale price index. This evidence he explained by "deviations of the actual gold supply from the normal gold supply" ${ }_{6}$ and "variations in the monetary demand for gold."'s?

On the second score, he alleged that only Britain had a completely convertible currency in the prewar period; other countries usually put barriers in the way of the large gold exports and "eagerly watched their gold reserves." Indeed, he argued that by the end of the period most countries kept large gold reserves as a matter of national pride and consequently the key aim of policy was to protect the gold reserve rather than use the gold reserve to protect convertibility. Thus when World War I broke out, the redeemability of currency was immediately suspended in order to safeguard the gold reserve.

Like Cassel, Viner (1932) argued that the prewar gold standard

would . . . have been found impracticable and would have been generally abandoned . . . [if not for] the development of a deliberate and centralized mechanism of control of gold movements, using central bank discount policy and credit control as its chief instruments. (Viner 1932, p. 9)

Moreover, the Bank of England pioneered in the development of the technique of central-bank control. England became the manager of the international gold standard.

However, the evolution of the Bank of England's effective management of the gold standard emerged as a by-product of the Bank's learning by a process of trial and error to protect its slim gold reserves. The Bank of England in the nineteenth century was primarily a profit-seeking institution and hence tried to minimize its non-interest-bearing gold holdings. However, by the close of the century, the Bank gradually began to accept responsibility for maintenance of an English gold standard: ${ }^{58}$ 
The Bank of England, at first as the sole issuer of paper money and the most important deposit bank, later under pressure of public opinion and in self-defense against the irresponsibility of the other English banks, partially accepted the role of a central bank with some degree of special responsibility for the mode of operation of the English gold standard and especially for the protection of the convertibility of the English paper currency. (Pp. 12-13)

As a consequence, the Bank learned to makes its discount rate effective to protect its gold reserve in the face of an external drain and to hold adequate reserves to meet the exigencies of both external and internal drains. $^{59}$

Moreover, according to Viner, in the nineteenth century fluctuations in the exchange rates within the gold points and short-term capital flows aided the adjustment mechanism and reduced the size of gold flows necessary to offset a disturbance to the balance of payments. Finally, Viner made a case for the continuation of the gold standard, despite the fact that it did not produce a stable price level, because a system of inconvertible paper currencies linked by flexible exchange rates would be far worse. ${ }^{\infty 0}$

We know too little ... of the possibilities of stabilization to take immediately any major steps in that direction. The hostility of central bankers and the menace of political control are genuine and important factors in the situation. The gold standard is a wretched standard, but it may conceivably be the best available to us. Its past record, bad as it is, is not necessarily conclusive in this respect, as the only alternatives which have actually been tried have, on the whole, had an incomparably worse record. (P. 37)

\section{The Conflict between Internal and External Goals}

A major theme of the interwar period was the potential conflict between internal price stability and a fixed exchange rate under the gold standard. By fixing the price of gold in terms of domestic currency, movements in internal price levels (and real income) would be determined by external-price-level (and real-income) movements. The prewar gold standard period, characterized by both price stability (in a long-run sense) and fixed exchange rates, was an accident of history, never to be repeated. At the same time, flexible exchange rates and abandonment of the gold standard rule were not embraced because of the risk of unstable exchange rates and the fear of the consequences of discretionary policy. That theme is echoed in the works of Keynes, Cassel, Viner, Nurkse, and others. To remedy the conflict between external and internal goals, various schemes were proposed to promote international harmonization of price-level movements under a managed gold standard. The views of major writers of the interwar period are surveyed briefly below. 
For Keynes ([1923] 1971) the policy options facing Great Britain in the immediate postwar period were to go back to the gold standard at the prewar parity, which would involve deffation, or else to fix parity after devaluing the pound. The choice between devaluation and deflation was part of a more general dilemma-the choice between price stability and exchange-rate stability. Keynes then asked, "In the light of our answers to the first two questions, is a gold standard, however imperfect in theory, the best available method for attaining our ends in practice?" ([1923] 1971, p. 117).

Because of its adverse affects on income distribution, Keynes rejected deflation. When internal and external price stability were incompatible, he chose internal price stability. Under the prewar gold standard, the choice was made in favor of fixed exchange rates and the subservience of the internal price level to external considerations. "We submitted, partly because we did not dare trust ourselves to a less automatic . . . policy, and partly because the price fluctuations experienced were in fact moderate" (p. 126). But the circumstances of the pre-1914 era were partly accidental, and it should not be presumed they would ever be repeated again.

The special conditions Keynes cited for the past good performance of the gold standard were first,

that progress in the discovery of gold mines roughly kept pace with progress in other directions-a correspondence which was not altogether a matter of chance, because the progress of that period, since it was characterized by the gradual opening up and exploitation of the world's surface, not unnaturally brought to light pari passu the remoter deposits of gold. But this stage of history is now almost at an end. A quarter of a century has passed by since the discovery of an important deposit. Material progress is more dependent now on the growth of scientific and technical knowledge, of which the application to gold mining may be intermittent. (P. 133)

Second, the independent influences coming from the demand for gold in the arts and for hoarding purposes in Asia had a steadying influence. Third, central banks allowed their gold reserves to vary slightly, absorbing much of the additional gold produced after major discoveries and reducing some of their accumulated gold when it was relatively scarce. They thus minimized the effects on price levels.

Given the special circumstances that made the gold standard successful before World War I, Keynes argued that the standard would be unlikely to work as well in the postwar period. Even if all countries adopted the gold standard-an important condition for it to be successful-the prewar system of balance-of-payments adjustment was "too slow and insensitive in its mode of operation" to handle the "large [and] sudden 
divergences between the price levels of different countries as have occurred lately" (pp. 128-29). Moreover, though short-term capital flows in response to interest-rate differentials helped speed up the adjustment mechanism in the prewar period, especially when the disturbance was temporary, in the case of permanent disturbances, the adjustment "might obscure the real seriousness of the situation, and enable a country to live beyond its resources for a considerable time at the risk of ultimate default" (p. 130). This problem would be more serious in the postwar period.

The case for flexible exchange rates and managed fiduciary money was that balance-of-payments adjustment to external shocks would be much more rapid under flexible than under fixed rates despite the risk of instability. ${ }^{61}$ Thus Keynes came out strongly against restoration of the classical gold standard by the United Kingdom.

In truth, the gold standard is already a barbarous relic. All of us, from the Governor of the Bank of England downwards, are now primarily interested in preserving the stability of business, prices, and employment, and are not likely, when the choice is forced on us, deliberately to sacrifice these to outworn dogma, which had its value once, of $£ 3$ $17 s .101 / 2 d$. per ounce. Advocates of the ancient standard do not observe how remote it now is from the spirit and the requirements of the age. A regulated nonmetallic standard has slipped in unnoticed. It exists. (P. 138)

In contrast to his earlier focus on the policy dilemma facing one country alone, Keynes ([1930] 1971) concentrated on the international monetary system as a whole. The interrelationship between central banks in an international fixed-exchange-rate system such as the gold standard was analogous, he noted, to the relationship between commercial banks and the central bank within a national economy. ${ }^{62}$

Under the pre-World War I gold standard, commercial banks operated in step within one country and central banks operated in step internationally except that reserve ratios did adapt somewhat to relative scarcity or abundance of gold. Behavior of the long-run price level depended on whether new gold available for reserves was increasing faster or slower than trade of the gold standard countries, which in turn depended on the rate of discoveries and technological improvements in gold mines, the use of gold as currency, the number of countries joining the gold standard, and the growth of real per capita income.

Some important differences in the relationship between central banks under the gold standard and between member banks and the central bank in a national economy, however, Keynes observed, were that central banks tended to have more variable reserve ratios; ${ }^{63}$ that more of its own money returns to the central bank than is the case for a commercial bank; 
that there is a higher degree of competition for short-term capital between central banks through varying discount rates than is the case between commercial banks. ${ }^{64}$

Thus in an international system, a central bank can pursue an independent policy—oriented primarily to domestic considerations-only within narrow limits and for short periods, with the degree of independence determined by its relative size. Thus, under a fully operative gold standard, "credit cycles have an international character" because member central banks must follow the average behavior. This implies a "real divergence of interest; and we must not expect of central banks a degree of international disinterestedness far in advance of national sentiment and of the behaviour of other organs of national government" ([1930], 1971, p. 257).

The dilemma between internal-balance and external-balance considerations for one country on the gold standard is thus apparent. ${ }^{65}$ Keynes argued that in a world of perfect capital mobility, the domestic interest rate must correspond to world interest rates:

If any country tried to maintain a higher rate than its neighbours, gold would flow towards it until either it gave way or the international system broke down by its having absorbed all the gold in the world. And if it tried to maintain a lower rate, gold would flow out until either it gave way or had to leave the international system through having lost all its gold. Thus the degree of its power of independent action would have no relation to its local needs. (P. 271)

The problem arises for a country

if its foreign balance is inelastic, and if, at the same time, it is unable to absorb the whole of its savings in new investment at the world rate of interest. It will also tend to happen even where the foreign balance is elastic, if its money costs of production are sticky. . . . This, then, is the dilemma of an international monetary system-to preserve the advantages of the stability of the local currencies of the various members of the system in terms of the international standard, and to preserve at the same time an adequate local autonomy for each member over its domestic rate of interest and its volume of foreign lending. (Pp. 271$72)^{66}$

As a solution to the problem, Keynes advocated a number of policies to increase the discretion of national monetary authorities while still remaining on a gold standard. One set of policies to protect a country's domestic stability in the face of "inconvenient fluctuations in the rate of foreign lending" is to maintain a large enough level of reserves: either in gold reserves at home or by holding "liquid balances in foreign centers," by arranging overdraft facilities with other central banks or by "borrowing and lending arrangements between central banks and a supernational 
bank" (p. 278). A second policy is to manipulate the gold points--to create an artificial spread between the official buying and selling price of gold. This can be done by direct authority or by the central bank manipulating the forward rate of exchange. ${ }^{67}$ Finally, he suggested direct controls over capital movements. Keynes's ideal solution to the problem of combining an ideal international standard and internal equilibrium was a gold standard managed by a supernational bank..$^{68}$

The objectives of a supernational monetary agency would be to ensure long-run stability and to smooth short-run cycles around the long-run trend. One way to achieve long-run price stability would be to adopt a commodity standard based on an international aggregate of commodities. "The long-period trend in the value of gold should be so managed as to conform to a somewhat crude international tabular standard" (p. 351). To solve the problem of short-run disturbances within individual countries, Keynes advocated giving individual central banks more discretion within the fixed-exchange-rate system.

The supernational bank would be established by all the world's central banks and would act as a lender-of-last-resort to them alone. It would hold as assets gold, securities, and advances to central banks, and its liabilities would be deposits by the central banks. These deposits, called supernational bank money (S.B.M.), would be fully convertible into gold and would serve along with gold as reserves for the member banks. The supernational central bank would then use the normal tools of monetary policy_bank rate and open-market operations - to "maintain . . the stability of the value of gold (or S.B.M.) in terms of a tabular standard based on the principal articles of international commerce" and to avoid "general profit inflations and deflations of an international character" (p. 360).

The interwar criticism of the traditional approach to the gold standard culminated in a provocative and path-breaking article by Whale (1937). He challenged both the price-specie-flow adjustment mechanism and the operation of the rules of the game.

Whale referred to four pieces of puzzling evidence: (1) Taussig's finding that the adjustment of national price levels to disturbances occurred much more rapidly than the theory postulated; (2) Beach's finding that gold flows to Great Britain moved procyclically contrary to the classical prediction, and that they were more closely related to interestrate differentials than to price-level differences; (3) the finding that many prewar central banks did not follow the rules of the game, e.g., the central banks of France and Belgium rarely changed their discount rates yet remained on the gold standard; (4) the finding that price levels between regions with varying levels of economic activity moved synchronously, suggesting a linkage through arbitrage rather than adjustment with a lag to specie flows, as in the traditional theory. ${ }^{69}$ "Might not the 
national price level be similarly determined by the world system of prices?" (Whale 1937, p. 22).

On the basis of this evidence, Whale suggested an alternative hypothesis to the classical mechanism: Rather than the demand for money in an open economy with a fixed exchange rate adjusting to the supply of money (and specie flows) as the classical theory predicts, specie flows and the money supply are determined by the demand for money, which in turn is determined by real income and the price level.

Thus, according to Whale, an increase in real economic activity, for a given price level (determined by the world price level), would increase the demand for money, causing a balance-of-payments surplus and a gold inflow. Similarly an increase in the domestic money supply would lead to a balance-of-payments deficit, a gold outflow, and a decline in the reserves of the banking system. If the markets of the country are closely linked with foreign markets, the decline of bank reserves should lead to "an almost immediate correction" of the money supply (p. 27).

Interest rates also play a different yet still important role in the alternative mechanism:

What is contended is that . . the raising of interest rates did not have the effect of producing a relative reduction of prices in certain countries. High rates in London led rather to a world fall in prices, partly because of the sympathetic movement of rates elsewhere, partly because of the effect on British entrepot trade and British long-term foreign investment. (P. 27)

Two important implications follow. First, the classical transfer mechanism of Mill and Taussig must be reinterpreted. According to Whale, a transfer of capital involves a redistribution of spending power. However, rather than this process involving a change in the direction of demand and in the terms of trade, "the redistribution of spending power itself, ... apart from any change in the direction of demand and the terms of trade, may require a redistribution of money . . . effected by a movement of gold" (pp. 28-29). Second, "since gold movements . . . and discount rate adjustments are displaced from their central position in the process of international price adjustment, the question of 'observing the rules of the game' . . . loses much of its importance" (p. 31).

\section{Appendix E Post-World War ll Reinterpreters of the Gold Standard}

In the period since World War II, economists have reexamined and reinterpreted the operation of the classical gold standard on the basis of new evidence and new theoretical and statistical tools. The principal 
areas of research are the adjustment mechanism, the role of capital flows, the managed gold standard, and the rules of the game.

In the reconsideration of the international adjustment mechanism, several approaches can be distinguished. The Keynesian open-economymultiplier approach (Ford) explains most of the adjustment to the transfer of capital before World War I in terms of changes in economic activity rather than relative price levels. Extension of the classical price-specieflow mechanism (Friedman and Schwartz) focuses on relative price levels and interest rates in the adjustment process. The monetary approach to the balance of payments (Triffin, Williamson, and McCloskey and Zecher) integrates elements of both Keynesian and classical mechanisms and views gold flows by themselves, rather than the effects they have on price levels, incomes, and interest rates, as the equilibrating mechanism in the adjustment of the balance of payments.

A major reexamination of the role of capital flows in the transmission mechanism (Morgenstern) raised serious doubts about the classical theory, though the analysis in turn was criticized (Borts). Evidence favorable to the traditional approach was also presented (Bloomfield).

Evidence on the managed gold standard amplified the view that London managed the prewar gold standard (Lindert, Sayers, Goodhart). Other studies showed that the rules of the game were largely violated before 1914 (Bloomfield) and that they were inconsequential (McCloskey and Zecher).

\section{The Adjustment Mechanism}

Ford (1962) downplayed the role of price-level and monetary change in the explanation of the adjustment of the balance of payments under the prewar gold standard. He stressed three themes: (1) the key element in the adjustment mechanism for Great Britain was the change in real income, working through an open-economy-multiplier process; (2) the important link between Great Britain and periphery nations via lending and exports worked primarily through changes in income; (3) there was an asymmetry between the gold standard experience of Great Britain and Argentina (an example of a periphery country). For Great Britain the gold standard mitigated the adjustment to external disturbances, for Argentina the gold standard aggravated it. These divergent experiences reflected the operation of fundamentally different gold standard financial institutions and the presence and absence of "other favorable circumstances." Ford was highly critical of the stylized facts of the traditional approach summarized in the Cunliffe report. His objections were that the report omitted the crucial role of income effects; placed weight on a link between changes in interest rates and economic activity that he believed to be tenuous; treated relative prices as the primary mechanism of adjustment in the balance of trade, based on the doubtful assumption of 
elastic demands for imports and exports; inappropriately ignored the feedback effects of changes in income of the major trading nation--Great Britain-on other countries; and made no mention of the important role of foreign lending.

Instead, Ford emphasized the key role of changes in income in the balance-of-payments adjustment mechanism. ${ }^{70} \mathrm{~A}$ disturbance to the balance of payments such as the exogenous decline in exports would reduce much of the initial balance-of-payments deficit by a decline in real income, working via the multiplier, and would reduce the demand for imports without any change in price levels. ${ }^{11}$ The extent to which the balance of payments was equilibrated, without requiring a gold outflow and changes in the money supply, depended on the relative sizes of the marginal propensities to import and to save. ${ }^{72}$ In addition, feedback effects of changes in other countries' income due to the fall in British demand for their products would (depending on the size of the other country) also facilitate the adjustment.

The second adjustment mechanism was change in the money supply. To the extent the balance of payments was not equilibrated by income change, the resultant gold outflow would reduce the domestic money supply, which would raise interest rates and lower domestic economic activity, imports, and the balance-of-payments deficit. The rise in interest rates would also induce a short-term capital inflow, providing a temporary cushion for the balance of payments. A rise in the central bank's discount rate would further stimulate the reduction in domestic activity and encourage a short-term capital inflow. However, Ford did not regard the Bank of England's playing by the rules of the game as the key element in the process, and he downplayed the accommodating role of centralbank policy in other countries. ${ }^{73}$

Finally, Ford presented evidence he regarded as consistent with the key role of income in the adjustment process for Great Britain. Comparing deviations from a nine-year moving average of exports, imports, and income from 1870 to 1914 , he found that

the parallelism between movements of deviations from nine year moving averages of exports, imports and national income is marked, with some slight tendency for imports to lag behind exports, . . . these movements provide powerful evidence both for the exports-incomeimport automatic adjustment mechanism and for the view that in most British booms and slumps variations in export values were a vital factor. (Ford 1962, p. 61)

According to Ford, British loans to developing nations such as Argentina, Australia, and Canada were primarily transferred through changes in real income, in contrast to the classical approach which emphasized changes in sectoral prices. A British loan to a country like Argentina 
would lead to an increase in imports from Britain and an increase in debt service. When the investment projects in the borrowing country matured, production of exportables would increase, some of which would be imported by Britain. The resultant rise in Argentine incomes would then generate the revenues necessary to service the foreign debt as well as increase demand for British goods.

The arrangement worked well in the long run, but in the short run problems could arise for the borrowing country. If the amount lent abroad temporarily exceeded Britain's current-account surplus, a gold outflow from Britain would occur, and the Bank of England would raise Bank rate. As a result, the borrowing country would experience a gold outflow. Important investment projects might be halted before completion leading to a balance-of-payments crisis if the borrower were unable to meet the debt-service obligations.

Ford examined in detail the cyclical adjustment mechanism in Argentina under the gold standard (and under inconvertible paper). The typical cycle can be described as follows: A rise in the price of Argentina's primary staple exports, generated by an increase in foreign demand, would produce a current-account surplus, a rise in economic activity, and a gold inflow. The gold inflow would lead to a rise in the domestic money supply. Some of the increased expenditure would go to the production of additional exports, some to the purchase of imports, and some into the nontraded sector-primarily for the purchase of land. A land boom would develop, followed by further foreign investment and further expansion. Ultimately, the boom would be choked off, either by a reduction in foreign economic activity that reduced the demand for Argentinian exports, or by a rise in the discount rate by the Bank of England to offset a gold outflow. Furthermore, were speculation in land to get out of hand, there would ultimately be a collapse in land prices and a domestic liquidity crisis associated with bank failures. Foreign lending would be discouraged. If the internal drain were accompanied by an external drain, then domestic gold reserves would be insufficient to withstand the onslaught and the country would suspend convertibility. This was the sequence of events in 1885 and 1913.

Ford argued that the gold standard experience of periphery countries such as Argentina was considerably less favorable than that of center countries such as Britain. For two reasons the cycle in British economic activity was dampened by the gold standard whereas the cycle in Argentina was aggravated. First, Britain's position as the center of the world's money market meant that in the face of an external drain, a rise in Bank rate would draw on short-term capital and sterling balances in London without loss of gold, while Argentina lacked the cushioning financial institutions. ${ }^{15}$ Second, it was easier for a cre ditor nation to obtain immediate relief from external pressure by reduced foreign lending, "whereas 
... in a period of stringency it was difficult or even impossible for a debtor country (with a past history of depreciation) to offset gold exports by increasing its borrowing abroad" (p. 182).

In their monumental study of U.S. monetary history, Friedman and Schwartz (1963) treated the gold standard in a traditional way in their analysis of the role of monetary forces and of the price-specie-flow mechanism to explain balance-of-payments adjustment under the gold standard; in their application of the commodity theory of money to explain secular price movements; and finally, in their discussion of the role of central-bank management under the gold standard.

They described the role of the money supply under an international specie standard that the United States adhered to from 1879 to 1933 , as follows:

The amount of money in any one country must be whatever is necessary to maintain international balance with other countries on the same standard, and the amount of high-powered money will alter through imports and exports of specie in order to produce this result . . . the amount of high-powered money is a dependent rather than an independent variable, and is not subject to governmental determination. (Friedman and Schwartz 1963, pp. 51-52)

Moreover,

for a country which is an economically minor part of the gold standard ... the major channel of influence is from fixed rates of exchange with other currencies through the balance of payments to the stock of money, thence to the level of internal prices that is consistent with these exchange rates. . . [However] the links have much play in them, so that domestic policies can produce sizable short-term deviations in the stock of money from the level dictated by external influences. (Pp. 89-90)

Under a flexible-exchange-rate regime, by contrast, such as the greenback period from 1862 to 1879 , "the amount of high-powered money is determined by governmental action" (p. 51).

Adjustment to both external and internal disturbances was facilitated by the classical relative-price-level adjustment mechanism and capital flows. The events of the period 1879-82 are analyzed in these terms. Good harvests in 1880-81 led to an increase in U.S. exports. The resulting increase in demand for dollars implied a relatively higher U.S. price level consistent with balance-of-payments equilibrium. ${ }^{76}$ Pending the rise in prices, a gold inflow ensued that led to a rise in the money stock and the price level. At the same time, a gold outflow from Great Britain led to a monetary contraction and a decline in the price level. As a consequence the Bank of England raised Bank rate, reversing the gold flow to the United States. 
The gold inflow was a passive reaction which temporarily filled the gap in payments. In its absence, there would have had to be an appreciation of the dollar relative to other currencies-a solution ruled out by the fixed exchange rate under the specie standard-or a more rapid rise in internal U.S. prices. At the same time, the gold inflow provided the basis and stimulus for an expansion in the stock of money and thereby a rise in internal prices at home and downward pressure on the stock of money and prices abroad sufficient to bring an end to the necessity for large gold inflows. It would be hard to find a much neater example in history of the classical gold standard mechanism in operation. (P. 99)

Other episodes are treated similarly: prices and incomes, aided by capital flows, adjust to maintain external balance. " The brunt of the adjustment was sustained in some cases by changes in the money stock, in others by changes in velocity or real output.

Economically, these were the channels whereby a necessary adjustment was worked out. They were not the forces determining what adjustment was necessary. . . . The discipline of the balance of payments under the gold standard enforced that adjustment and determined its size. (P. 101) $)^{78}$

Friedman and Schwartz applied the classical commodity theory of money to explain secular price-level movements:

Under a specie standard confined to a single country, or for the world as a whole under an international standard, the existing amount of specie is determined by the available physical stock plus the relative demand for monetary and other uses; and changes in the amount of specie, by relative costs of production of specie and other goods and services. (P. 52)

They explained the secular deflationary episode of $1879-96$ by

[a] combination of events, including a slowing of the rate of increase of the world's stock of gold, the adoption of the gold standard by a widening circle of countries, and a rapid increase in aggregate economic output, . . . despite the rapid extension of commercial banking and of other devices for erecting an ever larger stock of money on a given gold base. (P. 91)

The subsequent turnaround in prices and secular-inflation episode is explained by

fresh discoveries of gold in South Africa, Alaska, and Colorado combined with the development of improved methods of mining and refining, especially the introduction of the cyanide process. These occurred during a period when there were few further important extensions of the gold standard yet a continued development of devices for "economizing" gold. (P. 91) 
Moreover, the period of secular defiation "was an important factor in stimulating the search for gold and for economical techniques for extracting gold from low-grade ore" (p. 188).

Finally, in their discussion of the sterilization of gold inflows in the 1920 s by the Federal Reserve system, Friedman and Schwartz explain how violations of the rules of the game weakened the adjustment mechanism of the gold standard.

The sterilization of gold could be justified as a means of insulating internal monetary conditions from external changes. Its international effect, however, was to render the maintenance of the international gold standard more difficult. Suppose all countries linked by a gold standard were to sterilize gold flows. Gold flows would then set in train no forces tending to bring them to a halt or to reverse them. The system could last only as long as the flows resulted from purely temporary imbalances of sufficiently small magnitude to right themselves before draining the countries losing gold of their reserves. The effect would be to insulate the countries from minor adjustments at the cost of letting them accumulate into major ones. (P. 283)

Friedman and Schwartz attributed the Federal Reserve system's failure to stem the banking crisis of 1931 to its failure to follow the classical medicine prescribed by Bagehot for central-bank operations in the face of both an external and an internal drain-to lend freely but at a high discount rate (p. 395).

Emphasis on the "stylized facts" of the gold standard on intercountry adjustment via specie flows that produced relative price-level adjustments, aided by capital flows and by central banks following the rules of the game, failed, according to Triffin (1964), "to bring out the broader forces influencing the overall pace of monetary expansion on which individual countries were forced to align themselves" (p. 2).

Evidence damaging to the traditional story included: "enormous degree of parallelism-rather than divergent movements-between export and import fluctuations for any one country, and in the general trend of foreign-trade movements for the various trading countries . . . from 1880 to 1960 " (p. 3); and "overall parallelism-rather than divergence-of price movements, expressed in the same unit of measurement, between the various trading countries maintaining a minimum degree of freedom of trade and exchange in their international transactions" (p. 4); downward wage rigidity among countries that maintained exchange stability; Bloomfield's (1959) evidence of the failure of most central banks to play by the rules of the game; the ineffectiveness of changes in discount rates in many countries to stem capital flows or change relative prices; and the important role of long-term capital flows in maintaining enduring balance-of-payments disequilibrium without relative price adjustment. 
Triffin accordingly painted a different picture of how the gold standard worked.

The most important aspect of the gold standard was exchange-rate stability maintained by "pressures for international harmonization of the pace of monetary and credit expansion [between central banks] similar . . . to those which . . . limit divergent rates of expansion among private banks within each national monetary area" (p. 11), enforced by the constraint of convertibility into gold of fiduciary money. ${ }^{79}$ Given stable exchange rates, then

national export prices remained strongly bound together among all competing countries, by the mere existence of an international market not broken down by any large or frequent changes in trade or exchange restrictions. . . National price and wage levels also remained closely together internationally, even in the face of divergent rates of monetary and credit expansion, as import and export competition constituted a powerful brake on the emergence of any large disparity between internal and external price and cost levels. (P. 10)

As a consequence, monetary expansion generating

inflationary pressures could not be contained within the domestic market, but spilled out directly . . . into balance of payments deficits rather than into uncontrolled rises of internal prices, costs, and wage levels. These deficits led, in turn, to corresponding monetary transfers from the domestic banking system to foreign banks, weakening the cash position of domestic banks and their ability to pursue expansionary credit policies. (Pp. 10-11)

Central banks could only temporarily slow down the adjustment process by engaging in offsetting open-market operations or using other tools of monetary policy, because ultimately their international reserve ratios would decline. Thus, in the gold standard world of fixed exchange rates, price levels were closely linked together and the balance-of-payments deficit (surplus) reflected both money-market disequilibrium and the method by which it was eliminated.

In an approach similar to that of Triffin, Williamson $(1961,1963)$ reinterpreted U.S. experience under the gold standard. He urged analysis of the balance of payments in a general-equilibrium context, with the long-swing cycle in the growth of real output determining specie and capital flows. ${ }^{80}$ Increased real growth would lead to both an excess demand for goods (a balance-of-trade deficit), an excess supply of bonds (a capital inflow), and an excess demand for real balances. The excess demand for money would be satisfied by a specie inflow, with little change in the price level, accompanied by a long swing in capital inflows (Williamson 1961, p. 379). The external balance was both a cause as well as a 
reflection of the long swing, since in the 1830s it was British demand for U.S. cotton that was the key source of the long swing in output, which in turn induced British investment in railroads and canals. ${ }^{81}$

In an important article applying the recently developed monetary approach to the balance of payments to the operation of the classical gold standard from 1880 to 1914, McCloskey and Zecher (1976) extended the challenge to the traditional approach intimated by Marshall in the $1880 \mathrm{~s}$, endorsed by Whale in the 1930 s, and repeated by Triffin and Williamson.

The monetary approach states that for an open economy with fixed exchange rates, the national stock of money, rather than prices, adjusts to changes in the public's demand for money (see Frenkel 1971; Johnson 1976; Mundell 1971). Contrary to the Hume price-specie-flow mechanism-which postulates significant lags in the adjustment of price--because of instant arbitrage, according to the monetary theory, no lags are observed in the adjustment of world prices. In the most rigid version of the theory, an increase in the demand for money cannot reduce prices because prices of internationally traded goods are determined in world markets and kept comparable in different countries by international arbitrage, and prices of domestic goods and services are kept in line with prices of internationally traded goods by domestic arbitrage. The reduction in the public's demand for goods and securities leads to reduced imports and expanded exports on the goods side and to higher interest rates and capital imports on the securities side. The current account or the capital account or both move into surplus. To prevent appreciation of the currency, the monetary authority buys foreign exchange from its nationals, paying out newly created high-powered money. The increase in high-powered money leads to a multiple expansion of the domestic quantity of money which continues until the public's demand is satisfied.

In open economies on a fixed exchange rate, a once-for-all increase in the quantity of money in one country and a decrease in another would produce a balance-of-payments deficit in the first and surplus in the second and lead to a flow of money to the second until equilibrium was reestablished. If a monetary authority in one country alone increased high-powered money, that would be equivalent to an increase in the world money supply. That country would experience a temporary balance-of-payments deficit until the world money supply was redistributed in proportion to the size of the country of issue, and the world price level would rise accordingly. In the long run, domestic monetary policy in a small country has a negligible influence on international prices, although in the short run the monetary authority can affect its price and income level by open-market sales (purchases) equal to its balance-of-payments surplus (deficit) that will maintain the national money stock below (above) its equilibrium value. The closer the links among world commodity markets, the higher the degree of capital mobility, the less scope for 
independent monetary policy in the short run. The greater the elasticity of substitution between traded and nontraded goods, the less successful will such policy be. In the long run, however, independent monetary policy is inconsistent with fixed exchange rates.

McCloskey and Zecher tested the key assumptions of commodity arbitrage by examining correlations among price changes between countries and between regions within countries. For traded goods such as wheat, they found synchronous correlations equally high between regions as between nations, unlike the case of nontraded goods such as labor services and bricks. For overall price indexes, they found a significant correlation between the U.S. and U.K. wholesale price indexes, less so for GNP deflators, and even less for consumer price indexes. The higher correlation for the wholesale price than for the other index undoubtedly reflects the larger share of traded goods in the former ${ }^{82}$

They conclude:

What has been established here is that there is a reasonable case ... for the postulate of integrated commodity markets between the British and American economies in the late nineteenth century, vindicating the monetary theory. There appears to be little reason to treat these two countries on the gold standard differently in their monetary transactions from any two regions within each country. (McCloskey and Zecher 1976, pp. 379-80)

They also cite less conclusive evidence in favor of capital-market arbitrage. They tested their model by comparing gold flows-predicted by a simple demand for money function less the money supply produced by domestic credit expansion-with actual gold flows and found a close relationship. In their view,

we have established at least a prima facie case for viewing the world of the nineteenth century gold standard as a world of unified markets, in which flows of gold represented the routine satisfaction of demands for money. (P. 385)

\section{Capital Movements}

Both short-term and long-term capital movements play an important role in the traditional approach to the gold standard. Short-term capital flows were to act as an equilibrating mechanism, to economize on gold flows and to reduce the burden of adjustment by changes in relative price levels. Private short-term capital movements, assumed to be highly responsive to interest-rate differentials (induced by changes in the discount rate), would act to equate interest rates (adjusted for exchange risk) in different money markets. Morgenstern examined the evidence in favor of the "solidarity hypothesis," that arbitrage would ensure uniformity of interest-rate differentials to exchange risk (measured by the difference of 
the exchange rate from the gold points), and found it to be inconsistent with the principles of the gold standard. Borts, in criticizing both his methodology and data, put Morgenstern's conclusions into serious doubt. Bloomfield found evidence that private short-term capital flows responded to interest differentials and expected exchange-rate changes as predicted.

Long-term capital flows, a key disturbing force in the traditional approach, were believed to have been well accommodated by the gold standard balance-of-payments adjustment mechanism. They allowed both developing debtor nations and mature creditor nations to run persistent balance-of-payments disequilibria without requiring adjustment in the balance of trade. Bloomfield's study supported the integral role of long-term capital flows in the development of the "Atlantic economy."

Morgenstern (1959) examined short-term-interest-rate data of different maturities, exchange rates, and the gold points for four key gold standard countries: Great Britain, France, Germany, and the United States in the periods 1870-1914 and 1925-38, subjecting the "assumption of international solidarity of money markets" to three tests. ${ }^{83}$

The first test compared derived exchange rates, based on cross rates in third markets, with the actual exchange-rate series. If arbitrage were effective, differentials between the series would vanish. Morgenstern found evidence of differentials persisting in both periods, but more so after World War I, with the greatest deviations occurring in periods of crisis or disturbance such as the 1890 Baring crisis.

The second test identified deviations of exchange rates beyond the median gold import and export points. Violations persisted for long periods, with greater frequency of deviations beyond the gold export point than beyond the gold import point.

The third test compared market-interest-rate differentials with the "absolute maximum permissible" differential determined by the distance between the gold points. Violation of the principle occurred in both prewar and postwar periods.

Morgenstern concluded that we ought to view

the period of the classical gold standard as inadequately described by the typical mechanism at least in one respect: the interaction between two and more money markets via exchange rates and interest rates is not nearly as precise and rigid as postulated (Morgenstern 1959, p. 569)

He explained these results by "friction" and central-bank intervention, suggesting the replacement of the interpretation of the gold standard as a mechanism by the notion that central banks and other market participants engage in game strategy in a struggle for gold. Borts (1964) criticized both Morgenstern's methodology and his data. Borts attributed the results of the first test comparing cross with own exchange rates to the 
methods of making exchange quotations. Morgenstern's data were either exchange quotations in the form of single prices at which brokers cleared the market or the average of bid-ask spreads. For Borts the bid-ask spreads were likely measures of transactions cost; hence "what appears to be an opportunity for arbitrage profit could be the difference between the clearing price and the prevailing practice of giving quotations" (Borts 1964, p. 225).

Borts found the results of the second test comparing the spot exchange rate with the gold points ambiguous. In deriving the gold points, Morgenstern assumed circumstances favoring his results since he took into account neither different methods of covering exchange risk nor frequent operations by the monetary authorities on the gold points. These ambiguities could be sorted out, according to Borts, by directly examining gold movements "in an effort to confirm the position of the exchanges with regard to the gold points" (p. 227) ${ }^{84}$

Finally, Morgenstern's third test comparing interest differentials to the maximum exchange risk on uncovered funds was faulty, in Borts's view, because (1) "[he converted] the percent movement in the exchange rate into a percent difference on one-year paper. The exchange risk . . . has no time dimension and exists no matter what the maturity of the paper held" (p. 227); (2) he did not account for possible forward cover. ${ }^{85}$

Bloomfield examined the role of both short-term (1963) and long-term (1968) capital flows under the pre-1914 gold standard. He suggested that private short-term capital movements served to equilibrate the balance of payments in the short run by tending to reduce the size of gold flows or acting as substitutes for changes in official exchange holdings (Bloomfield 1963 , p. 44). To test the latter hypothesis, he compared the signs of the first differences of annual changes in the stock of net foreign short-term assets of commercial banks with annual changes in the stock of centralbank gold and foreign-exchange reserves of the Scandinavian countries and found the postulated negative relationship (p. 58) ${ }^{86}$

Long-term capital flows in the classical gold standard period in the form of portfolio investment came mainly from Britain and France, followed by Germany; the bulk of the funds went to the developing countries of the new world to finance the development of infrastructure and production and exportation of primary products. Following the work of Williamson (1964), Cairncross (1953), O'Leary and Lewis (1955), and Thomas (1973), Bloomfield (1968, pp. 18-34) found evidence of a longswing cycle in long-term capital movements. Consistent with their theories, he found for debtor countries positive correlations between capital imports and indicators of domestic investment such as domestic building, and between capital imports and net immigration; for creditor countries a negative correlation between capital exports and domestic investment, and a positive one between capital exports and net emigration. ${ }^{87}$ These 
results, plus the evidence that similar long-swing movements in the United States and Canada in turning points were inversely related to swings in British building and economic activity in general, gave support to Thomas's (1973) thesis of an Atlantic economy. Finally, contrary to theory, interest rates did not explain movements in annual data of British capital exports and U.S. capital imports. In the multiple regressions that Bloomfield estimated, domestic and foreign investment activity were the significant regressors.

\section{The Managed Gold Standard}

The mainstream view of the classical gold standard that emerged from the interwar period (appendix D) was that it evolved into a sterling standard. The concentration of world capital, commodity, and gold markets in London made the pound sterling an attractive reserve asset in addition to gold and made it easier for the Bank of England to control its gold-reserve ratio by altering Bank rate, in the process affecting the policies of other central banks and influencing economic conditions both at home and abroad. ${ }^{8 s}$

In the post-World War II period, the degree of management of the prewar standard was further explored. Key currencies other than sterling were shown to have been important in the pre-World War I period, though sterling's role was still predominant, and the Bank of England's use of the Bank-rate weapon was deemed to be less effective than traditionally believed (Lindert 1969). The ways in which the Bank of England managed the gold standard were described (Sayers 1936, 1957; Goodhart 1972).

Following Bloomfield (1963), Lindert (1969, pp. 13-27) found that holdings of several major currencies-the pound, the franc, and the mark-represented an important and growing fraction of the international reserves held by many countries in the period $1900-1913 .{ }^{89}$ As expected, London was the primary reserve center for the world but francs and marks were popular on the Continent.

According to Lindert, key currencies were held for the interest income they earned; they involved lower transaction and transportation costs than gold, and maintenance of balances in a foreign currency such as sterling often gave easier access to credit in the London money market. Perhaps the key reason these currencies were held was that their good brand name guaranteed with certainty that they could be converted into gold on demand. In the case of the pound, the location in London of the international money market and the world's gold market likely enhanced its brand name.

Because their currencies were widely held, the central-reserve countries could run larger balance-of-payments deficits than otherwise and 
could maintain them longer. However each central bank was sensitive to its gold-reserve ratio and when it declined the bank would react by raising its discount rate. ${ }^{\% 0}$ Lindert found that when Great Britain raised Bank rate, other central banks on the Continent would respond, but London had stronger "pulling" power and could always attract short-term funds from the Continent." A flow of short-term funds proceeded from peripheral European nations, running balance-of-payments surpluses to Paris and Berlin, and then to London. The asymmetry in discount-rate drawing power may be explained by the fact that for the center countries, short-term foreign assets tended to be less liquid than short-term liabilities; "since tighter monetary policy tends to stimulate shifts toward liquid assets, banks would react by seeking greater key-currency balances at the expense of bills on lesser centers" (Lindert 1969, p. 78).

Thus, the indisputable position of London as the dominant financial center during the prewar years meant that "other countries, had, therefore, to adjust their conditions to hers." 92

After the publication of Lombard Street (Bagehot [1873]1969), the Bank of England began to take seriously its responsibilities for both maintaining convertibility and preventing domestic monetary instability, doing so not by increasing its gold reserves, as Bagehot suggested, but by altering its discount rate whenever its gold reserves were threatened (Sayers 1951, pp. 109-10).

Sayers described the prewar techniques used to make Bank rate "effective" in the sense of linking it tightly to short-term market rates. The methods included open-market operations, eligibility requirements, and the switch to a penalty rate in $1878 . .^{93}$ In addition, under special circumstances, when it feared the internal repercussions of raising Bank rate, the Bank would protect its gold reserve by using "gold devices"-direct operations in the gold market. It is generally agreed however that the Bank achieved full control over its reserves after 1890 (Presnell 1968).

According to the traditional approach, a rise in Bank rate would equilibrate the balance of payments via two principal channels: by inducing a short-term capital inflow (reducing an outflow) and by checking domestic economic activity, the domestic price level, and the price of imports. Lindert (1969, pp. 43-44), Bloomfield (1959, p. 42), and Goodhart (1972, chap. 15) evaluated the evidence for the domestic channel as indicating at best a weak and protracted adjustment with the case for the link via capital flows sacrosanct. The case made against the domestic channel was twofold: the limited response of the domestic money supply to changes in the Bank of England's gold reserve, and the limited response of domestic economic activity to changes in the interest rate.

With respect to the money supply, Goodhart $(1972$, p. 208) was unable 
to detect any close, positive association between the cash base (reserves) of the commercial banks, represented by bankers' balances at the Bank of England, and the Bank's gold reserves.

According to him, the direction of causation was the reverse of the traditional one. An increase in economic activity would lead to an increase in commercial-bank lending and deposits, and the increase in bank reserves required to maintain stable reserve ratios would be supplied by the Bank of England at the expense of its other discounts, thus producing both a lower gold-reserve ratio at the Bank of England (the proportion) and a higher discount rate. The rise in the discount rate would then lead to a gold inflow restoring the Bank's proportion. ${ }^{94}$

Goodhart concluded (1972, p. 219):

Indeed, on this view, the great years of the gold standard (1890-1914) were remarkable, not because the system enforced discipline and fundamental international equilibrium on this country by causing variations in the money supply, but because the system allowed for the development of such large-scale, stabilising and equilibrating, shortterm, international capital flows, that autonomous domestic expansion was rarely disrupted by monetary or balance of payments disturbances.

With respect to domestic economic activity, Tinbergen (1950, p. 133) found that

the influence of interest rates on the course of investment activitywhich is the chief influence interest rates exert, according to our results-is only moderate. A rise in interest rates depresses investment activity, but only to a modest extent.

and Pesmazoglu (1951, p. 61) that

variations . . in the long-term rate of interest did not have an important infuence on fluctuations of British home investment between 1870 and $1913 .{ }^{95}$

\section{The Rules of the Game}

According to the traditional approach, the key objective of monetary policy was to maintain convertibility into gold and to use monetary policy, specifically the discount rate, to facilitate internal adjustment to external disequilibria. However, Bloomfield (1959, pp. 25-26) found that while central banks were primarily concerned with maintaining convertibility, their policy actions were discretionary, not automatic:

Not only did central banking authorities . . not consistently follow any simple or single rule or criterion of policy, or focus exclusively on considerations of convertibility, but they were constantly called upon to exercise, and did exercise, their judgment on such matters as whether or not to act in any given situation and, if so, at what point of 
time to act, the kind and extent of action to take, and the instrument or instruments of policy to use. . . . It does indicate that discretionary judgment and action were an integral part of central banking before 1914 , even if monetary management was not oriented toward stability of economic activity and prices in the broader modern sense.

In a test of the extent to which central banks under the pre-1914 gold standard played by the rules of the game, Bloomfield interpreted the rules as meaning "that central banks were supposed to reinforce the effect of these flows [gold flows] on commercial bank reserves, not merely not to neutralize them. This implied . . that central banks were supposed to lower their discount rates in the face of persisting gains of gold . . . and to raise them when there were persisting losses." Such a policy would have the effect of "increasing central bank holdings of domestic earning assets when holdings of external reserves rose, and of reducing domestic assets when reserves fell" (Bloomfield 1959, p. 47).

Following Nurkse's approach in his examination of central-bank behavior in the 1929-38 period, Bloomfield compared year-to-year changes in international and domestic assets for twelve central banks in the 1880-1914 period and found that, in the case of every central bank, the changes in the two classes of assets were more often than not in the opposite direction (with the Bank of England coming close to being the exception to the rule).

Thus,

Far from responding invariably in a mechanical way, and in accord with some simple or unique rule, to movements of gold . . . central banks were constantly called upon to exercise, and did exercise, discretion and judgment in a wide variety of ways. Clearly the pre-1914 gold standard system was a managed and not a quasi-automatic one from the viewpoint of the leading individual countries. (Bloomfield 1959, p. 60)

Based on their reinterpretation of the classical gold standard according to the monetary approach to the balance of payments, McCloskey and Zecher (1976) denied that the Bank of England could have "acted as conductor of the international orchestra" as in Keynes's ([1930] 1971) description, but "was no more than the second violinist, not to say the triangle player, in the world's orchestra" (McCloskey and Zecher 1976, pp. 358-59).

The monetary theory holds that the world's economy is unified by arbitrage and that the world's price level is determined by the world's money supply. Then the Bank of England's

potential influence on prices (and perhaps through prices on interest rates) depended simply on its power to accumulate or disburse gold and other reserves available to support the world's supply of money. 
... Only by decreasing the securities and increasing the gold it held ... could the Bank exert a net effect on the world reserves . . . Had the Bank in 1913 sold off all the securities held in its banking department it would have decreased world reserves by only 0.6 percent; had it sold off all the gold in its issue department, it would have increased world reserves by only 0.5 percent. (McCloskey and Zecher 1976, p. 359)

Finally, according to McCloskey and Zecher, the central banks of the world ignored the rules of the game-stipulating that a deficit in the balance of payments be accompanied by contractionary monetary policy, a surplus by expansionary policy—because the rules were "inconsequential." According to the monetary theory "neither gold flows nor domestic deflation have effects on prevailing prices, interest rates, and incomes" (p. 361) since the central bank of a country adhering to the gold standard could only control the composition of the monetary base as between international reserves and domestic credit, not its total amount.

\section{Notes}

1. Some of the material covered is drawn from, and may overlap, earlicr surveys by Viner (1937), Fetter (1965), and McCloskey and Zecher (1976).

2. The meaning of the price of gold is its relative or real price or the purchasing power of gold. This meaning is not explicitly stated by all writers but presumably it is what they intended. It is the fixed mint price of gold in terms of national currency divided by some commodity price index.

3. For some writers changes in incomes rather than changes in relative price tevels produced the adjustments.

4. Some would argue that Adam Smith ([1776] 1976) should be included in this list. Smith subscribed to most of the views expressed by the other classical economists. $\mathrm{He}$ viewed the world specie stock and its exchange value in the long run as determined by the richness of gold and silver mincs. Hc also stressed the social saving of using papcr moncy for specie up to the point of convertibility. However, he did not discuss the price-specie-flow mechanism and his belief in the real-bills doctrine (see Mints 1945) has resulted in the downgrading of his contribution to the traditional view. Recently, however, Girton and Roper (1978) and Laidler (1981) have argued that Smith may have been correct after all, if interpreted according to the recent monetary approach to the balance of payments. According to these authors, Smith viewed a country such as contemporary Scotland as a small open economy on a fixed exchange rate with an exogenously determined price level. Under such circumstances, the quantity of money would adjust to the demand for money-a result consistent with both the real-bills approach and the absence of any change in the terms of trade.

5. This discussion draws heavily on Bordo 1983 .

6. Cantillon [1931] 1964, bk. 2, chap. 16. Indecd the intrinsic value of the precious metals and hence long-run supply is determined by the cost of production of the least productive mine (p. 101), i.e., by marginal cost. Temporary variations of the exchange 
value of money from its intrinsic value can be caused by changes in the demand for precious metals (for nonmonetary uses), but in the long run exchange value will equal intrinsic value (p. 97).

7. Other aspects of the traditional view mentioned in Cantillon's Essai include a discussion on capital mobility (pp. 191-93), the gold points (pp. 253,255, 257,261), the use of bills of exchange to settle international balances (pp. 229, 245, 247), and the operation of the forward exchange market (p. 259).

8. Viner $(1937$, pp. 316,319$)$ argued that the distinction between the law of one price as pertaining to the equality of prices stated in a common currency of identical traded goods, allowance being made for transport costs, and the price-specie-flow mechanism, which involved changes in the relative prices of import and export goods (the terms of trade), was held by all the classical writers. Samuelson (1971) viewed the "inconsistency" as an error of interpretation by Viner and others. According to him, when prices in each country are measured relative to wages, the equality of identical-traded-goods prices will hold after a gold discovery initially affects the money supply and prices in one country.

9. Also paper has the advantage that it is flexible and can be supplied quickly in periods of crisis (Ricardo [1816] 1951, p. 58).

10. In addition the issue of bank notes will produce the same effect as a gold discovery (Ricardo [1811] 1951, p. 55).

11. Ricardo also described the force of arbitrage in maintaining equality between prices (the value of money) in the country and in London ([1811] 1951, p. 87).

12. Because it was legal to export bullion, but illegal to export coin, the price of bullion would initially rise above the mint price. Eventually, however, people would evade the prohibition and melt coin into bullion (Ricardo [1811] 1951, p. 64n).

13. According to Sayers (1953), Ricardo perceived that the essential condition of a gold standard is not gold coinage, but convertibility into gold for international transactions.

14. Chronologically, Thornton preceded Ricardo by several years, but it is convenient to present his views following those of Ricardo.

15. The size of the gold reserve should be determined by the degree of confidence "between independent countries" and the "largeness of the balance between the independent places" (Thornton [1802] 1978, pp. 155-56).

16. There may, however, be distribution effects between gold mining and other countries since the reduction in the use of gold as money will reduce the price levels of mining countries relative to those of the rest of the world. In addition, there will be first-round effects depending on how the money is issued-by private bankers or the government. Money issued by bankers would lead to a fall in the interest rate, a capital outflow, and a gold outflow, with no effect on the price level. If issued by government or by private manufacturers, the initial effect would be on domestic prices, leading to a current-account deficit and a gold outflow.

17. Here Mill ([1865] 1961, p. 625) cited Ricardo (Principles, 3rd ed.,p. 143). "Gold and silver having been chosen for the general medium of circulation, they are, by the competition of commerce, distributed in such proportions amongst the different countries of the world as to accommodate themselves to the natural traffic which would take place if no such metals existed, and the trade between countries were purely a trade of barter."

18. This section is based on Bordo 1975. Note that Jevons ([1884] 1964) considered the same issue as Cairnes and in the course of his investigation constructed a price index to measure the extent of depreciation of the value of gold caused by the discoveries.

19. Cairnes also tested Ricardo's theory of comparative advantage in predicting Australia's switch from being a net exporter to a net importer of agricultural products, and the Cantillon transmission mechanism to predict the dispersion of price changes between different commodity groupings.

20. Cairnes argued that England and the United States, because of their efficient banking and credit systems, should gain relative to France and the rest of the Continent 
since they would require less gold to finance the necessary price rise. The gold flowing out of England into France would serve to displace silver, since France was on a silver standard. The displacement of silver would for a time act as a parachute preventing French prices from rising until gold completely replaced silver; at the same time the released silver would flow eastward and into the silver currencies of Asia, augmenting gold flowing there directly. At this point in an argument similar to that of Jevons ([1884] 1964), Cairnes pointed out that the "parachute effect" would not be as important as Chevalier (1859) maintained in preventing a rise in French prices, since gold and silver were substitutes, so that as gold currency substituted for silver, the price of silver would tend to fall along with the price of gold.

21. See Viner 1937 and Fetter 1965 for a complete history of the debates.

22. That was the recommendation of the currency school which argued that a mixed currency - one consisting of both specie and notes - should be made to operate as if it were a pure specie standard. See Fetter 1965, p. 130.

23. This was the banking school's position. For them convertibility into gold and free competition in banking were sufficient to maintain an adequate money supply consistent with both internal and external balance. See Viner 1937, pp. 222-24.

24. See Viner 1937, pp. 264-70, and White (1981) who has reformulated the currencybanking schools debate as turning on the question whether to centralize the right of note issue in a single institution or to allow competition ("free banking").

25. In addition, Bagehot was in favor of publication of the accounts of the Banking Department of the Bank of England and employing more professionals and fewer amateurs in the government of the Bank ([1873]) 1969, pp. 302, 72).

26. Also Marshall stated that "a person who had to bring home the returns of any sales in a country had to elect what commodity he would bring, and the question whether he should bring lead or tin was governed . . . by exactly the same conditions as whether he should bring lead or gold. If after allowing for expenses of carriage you get a little more by bringing home the lead and selling it than by bringing home the tin, he would choose the lead; if he would get a little more by bringing home gold and selling it, he would bring home the gold" (1926, p. 121).

27. However this is only a temporary effect; in the long run changes in gold have no effect on the rate of interest, which is determined by "the average profitableness of different business" (Marshail 1926, p. 130).

28. The views on the gold standard of Fisher's contemporary, J. Laurence Laughlin (1903), according to Girton and Roper (1978), anticipated the monetary approach to the balance of payments. A critic of the traditional approach, Laughlin disagreed with the Hume price-specie-flow mechanism which postulated lengthy lags until relative-price-level differences led to corrective gold flows. He argued (in a manner similar to Angell, see p. 66 ) that commodity arbitrage tended to keep price levels of gold standard countries always in line. 1n addition, in the tradition of Adam Smith, he reversed the causation of money and prices of the classical quantity theory. According to Laughlin, for an open economy, the supply of money adjusted through the balance of payments to the demand for money, de termined in turn by the "needs of trade." Thus gold did not flow to equilibrate price levels but to satisfy an excess demand for (supply of) money.

29. Fisher cites a number of reasons why prices may not be equal. "Distance, ignorance as to where the best markets are to be found, tariffs, and costs of transport help to maintain price differences. . . . Practically, a commodity will not be exported at a price which would not at least be equal to the price in the country of origin, plus the freight" ([1922] 1965, p. 92).

30. Fisher also considered the case of bimetallism and rejected it on grounds similar to those noted by other classical writers-it tends to degenerate in to monometallism whenever the market ratio of gold to silver diverges from the official ratio ([1922] 1965, pp. 123, 325). $\mathrm{He}$ also argued against an irredeemable paper standard because of the inevitable tendency of governments to overissue (p. 131), against Marshall's symmetallism scheme because it 
bases the standard on too narrow a base of commodities (p. 328), and against a tabular standard: how to express money to conform to that standard was a problem (p. 335).

31. On the basis of a statistical investigation in 1933 of price-level movements of twenty-seven countries, Fisher found that the price levels of gold standard countries tended to move together, those of silver standard countries moved together, and the average price level of each group varied with changes in the relative priccs of gold and silver. Moreover, he found evidence for a short-run tradeoff between price-lcvel changes and changes in trade and employment within countries. Finally, evidence that countries not on the gold standard during the Grcat Depression, e.g., Spain and China, avoided the deflation suffered by gold standard countries and the concomitant contraction in output and employment, convinced him that "depressions travel internationally ... the infection is carried chiefly via the monetary standard" (1935, pp. 15-16).

32. See Jonung 1979 for a discussion of Wicksell's theory of pricc-level movements. Basically Wicksell argucd that price levels will rise cumulatively if the market ratc of interest, determined in the loan market, divcrged from the natural rate of interest, determined by the forces of thrift and productivity. If the market ratc wcre below the natural rate, prices would rise cumulatively, the price rise only being arrested by a gold outflow that would reduce the banking system's reserves, causing banks to raise their loan rate. When the market rate of interest was above the natural rate, a cumulative deflation would occur. Wickscll cxplained periods of secular inflation and deflation in the nineteenth century using this approach. In contrast to Wicksell, the Swcdish cconomist Cassel applied classical doctrine, explaining episodes of world inflation and deflation by the growth of the world's gold supply relative to the growth in demand for gold, the former influenced primarily by the production of new gold, the latter by the growth of real income.

33. Several years later A. G. Silverman (1931) tested the classical theory that capital cxports, ceteris paribus, would lcad to a rise in the price of imports relative to the price of exports. Using British data over the period 1880-1913, he compared "ycar to year percentage changes ... for the ratio of import to export prices . . . with year to year absolute differences for Hobson's indircct estimates of capital exports . . . expressed in terms of its average deviation" and found that over the whole period "an annual increase or decrease in capital exports is more often than not accompanied by an opposite change in the ratio of import to export prices." Thus he concluded that "the orthodox analysis . . . docs not seem to be borne out. For most of the period under consideration 'net barter terms of trade' in their yearly variations become more favorable with an increase in capital exports, and vice versa" (p. 124). His explanation for this result was that "an increase in British demand for foreign securities was apparently offset by an increased foreign demand for English goods" (p. 124).

34. In Canada, the primary recipient of the new capital, the opposite took place after 1900 - an improvement in the terms of trade and rising money wages. See the discussion on Viner, pp. $60-61$.

35. According to the theory, if the proceeds of the loan were spent in the lending country then the price-specie-flow mechanism would not operate (Taussig [1927] 1966, p. 230).

36. "Still another equalizing factor is the movement of securities that have an international market. They are sold betwcen the great financial centers in a way that replaces or lessens the transmission of gold. . . . In any given financial center, a tight money market and a high discount rate tend to lower the prices of ... international securities among them. . . . An inflow of gold, which might be expected to take placc toward the country of tight money, is replaced by an outward movement of securities" (Taussig [1927] 1966, pp. 218-19).

37. In a description of the monetary system of Great Britain, the United States, Canada, and France, Taussig demonstrated how different the responsc mcchanism to gold flows can be, ranging from the sluggish response of the French system with its high specie-money ratio to the rapid response of the British monctary system with its low gold-reserve ratio and 
loaned-up banking system. The Canadian system, with gold reserves held abroad in New York and London, gave the impression that deposits and notes increased before the gold inflow (Taussig [1927] 1966, pp. 201-7). Thus "in all countries using deposits and checks frccly, the looseness of the connection between bank reserves and bank deposits leads . . to a chronological order different from that assumed in the Ricardian rcasoning. An inflow of specic may follow, not precedc, an enlargement of the circulating medium and a rise in prices. So it may be, at least, for a short time, even for a period of many months. Indeed, if there be further forces at work than those merely monetary, it may remain so for years" (pp. 207-8).

38. In his analysis of the massive capital inflows to Canada, Taussig statcd, "If the world level of prices had remained unchangcd, wc should have expected in Canada a fall in the prices of imported goods, and a rise in the prices of domestic goods. Exported goods in the long run would have shown a movement similar to that of the domestic, but with a lag which would for some time keep their prices either on the same low level as the imported, or in a position intermediate between that of the imported and the domestic articlcs" ([1927] 1966, p. 228).

39. Beach 1935 , p. 180. In an appendix, he prescnted evidence for the United States, supportive of this cxplanation, that agrees with an earlier study by A. P. Andrew (1907).

40. Viner's contribution is summarized in Taussig [1927] 1966, chap. 19. For the literature critical of Viner, see Meier 1953 and Dick 1981.

41. Until 1935, although the largest commercial bank, the Bank of Montreal, performed many of the functions of a central bank. See Rich 1978.

42. Viner disputed Laughlin's view that all pricc levels arc ticd together via arbitrage, citing large differences in the price of gold among countries (Viner 1924, p. 206). He distinguished between traded goods, whose prices are closely linked internationally, and domestic goods, whose prices are only affected indirectly.

43. Howcver, prices of most Canadian exports were determined internationally, hence the rise in the price of international goods produced in Canada by the increased pricc of domestic goods and services would cause a decrcase in exports.

44. Also an index of the pricc of services rose rclative to the overall price index, as did an indcx of money wages relative to those in the United States and Great Britain, confirming the relative price adjustment mechanism (Viner 1924, pp. 241, 248).

45. Much of the reduced exports came from the diversion of raw materials to domestic usc, while a large share of the increased imports consisted of capital goods, largely from the United States-both forces conducive to economic development. The fact that most of the proceeds of the loan were not spent in the lending country, Great Britain, is given as further verification of the classical mechanism, which otherwise would not come into play. See Taussig [1927] 1966, pp. 230 and 259, where he states, "It was to be expected that Canada, getting a growing excess of imports over exports in terms of money, should also get more imported commodities in proportion to her commodities exported. But for the verification of theory it is particularly significant that the net barter terms also become more favorable. The Canadians not only got morc of physical goods in proportion to the goods they scnt out, but they got, on better terms, those imported goods which may be regarded as coming in payment for their own exported goods, and which had no relation to the borrowings."

46. White 1933, p. 303. Nevertheless, he concluded that "the influcnce of sectional price changes as a forcc in the adjustment docs not in the case of France appcar to have playcd so prominent a role as is presupposed by the neo-classical doctrine. . . Shifts in demand schcdulcs wcrc doubtless a more cffective medium. No substantiation of this view could be found in the French trade statistics, but actual substantiation would in any case be impossible because fluctuations in prices as a causal factor in merchandise movements could not be excluded; it would be impossible to determine what proportion of the changes in the volumc of merchandise imports and exports was due to changes in demand schedules and what proportion to changes in scctional priccs." 
47. See Kindahl 1961 and Friedman and Schwartz 1963 for further discussion.

48. According to Graham, in the first period, exporters to the United States will obtain for a time practically the same paper prices as before the lending. and these translated into gold will be higher than before. At the same time import prices in Great Britain will rise because the gold obtained by American sellers for their products when translated into paper yields less than before the depreciation of gold. Unless the British buyers can import from some other country, the U.S. sellers will gradually be able to raise their prices. The ultimate effect will be a rise in the British price level which will appear as a relative increase in the price of domestic goods. The opposite forces will occur in the second period (Graham 1922, pp. 259-60).

49. According to Nurkse ([1944] 1978), the general picture of the adjustment process and the role of central-bank policy presented in the Cunliffe report "was one which during much of that [interwar] period dominated men's ideas both as to the actual working of the gold standard before 1914 and as to the way the gold standard should be made to work after its restoration" (p. 67). Thus the prewar gold standard was portrayed in similar terms in both the Interim Report of the Gold Delegation of the Financial Committee (League of Nations [1931] 1979) and the Macmillan report (1931).

50. The report ignored the role of fluctuations in the exchange rate within the gold points and the temporary sterilization of gold flows.

51. The rules were never formally spelled out. According to the Macmillan report (1931), "the management of an international standard is an art and not a science, and no one would suggest that it is possible to draw up a formal code of action admitting of no exceptions and qualifications, and adherence to which is obligatory, on peril of wrecking the whole structure" (par. 47).

52. Moreover Gregory doubted the ability of forward exchange markets to cover exchange risk because he felt that "just when the relative values of currencies are most uncertain and when, therefore, the advantages to be derived from the organization of a forward exchange market would be greatest, the difficulties of organizing it . . . are greatest also" ([1932] 1979, p. 10).

53. This theme also appeared in the prewar literature in Keynes [1913] 1971. See the discussion below. It has played an important role in the postwar explanation of the classical gold standard's success. See, e.g., Triffin 1964, Lindert 1969, D. Williams 1968, and Palyi 1972.

54. Behind this elaborate network of financial flows was the real process of the transfer of capital to developing countries from the developed countries and the real flow of goods through the current account. According to Williams (1947, p. 155), "England's creditor position in the nineteenth century had developed gradually, along with the development of a world economy involving the division of productive effort between the older industrialized areas and the younger agricultural areas and the flow of accumulated savings from the former to the latter. The same circumstances which assigned to England the leading role in capital export made London the international money market and the Bank of England the administrator of the gold standard."

55. Important pre-1914 European examples were Austria-Hungary and Russia. In Asia, India and the Philippines represented the classic successful examples of the operation of the gold-exchange standard.

56. Calculated on the basis of the underlying trend growth rate of real income. See Cassell in the Interim Report . . of the Financial Committee (League of Nations [1931] 1979).

57. Among the key sources of variation in monetary demand in the pre-World War I era were "the large accumulation of gold in the United States in preparation for the introduction of the gold standard" in 1879 (Cassell 1935, p. 11), and the competition by central banks to strengthen their gold reserves: "the orthodox use of gold reserves for ironing out temporary deficits in the balance of trade fell into the background and often lost all 
importance in comparison with the gold movements caused by competition for gold and ultimately traceable to the artificial position given to gold in the world's monetary system" (p. 13).

58. Viner (1937) described how the conflict between private and public interests of the Bank was resolved in the period 1844 to 1870 . Also see the discussion above on Bagehot (p. 46).

59. Not however without courting disaster on numerous occasions (Viner 1932, p. 16); also, Viner 1937, pp. 259-74.

60. Viner's (1937) chronicle of the history of nineteenth-century debates over the monetary standard centered on the role of discretionary management under a gold standard rule. "Although most present day writers seem to believe either that the non-automatic character of the modern gold standard is a discovery of the postwar period or that it was only in the postwar period that the gold standard lost its automatic character, currency controversy during the entire nineteenth century concerned itself largely with the problems resulting from the discretionary or management elements in the prevailing currency systems. The bullion controversy . . . turned largely on the difference in the mode of operation in the international mechanism of a managed paper standard currency, on the one hand, and of a convertible paper currency, on the other, with the latter treated generally, but not universally, as if it were automatic. Later, the adherents of both the currency and the banking schools distinguished carefully between the way in which a supposedly automatic 'purely metallic' currency (which, in addition to specie, included bank deposits but not bank notes) would operate and the way in which the Bank of England was actually operating a 'mixed' currency (which, in addition to specie and bank deposits, included bank notes)" (pp. 388-89).

6l. "This means that relative prices can be knocked about by the most fleeting influence of politics and of sentiment, and by the pcriodic pressurc of seasonal trades. But it also means that the postwar method [of flexiblc exchange rates] is a most rapid and powerful corrective of real disequilibria in the balance of international payments arising from whatever causes, and a wonderful preventive in the way of countries which are inclined to spend abroad beyond their resources" (Keynes [1923] 1971, p. 130).

62. The analogy holds perfectly if we assume that each central bank has a rigid goldreserve ratio so that the aggregate quantity of central-bank money is determined by the aggregate gold reserves of the central banks; that no gold is used as currency; and hence that variations in the world monetary gold stock are determined by the difference between the amount of new gold mined and the amount consumed in the arts (Keynes [1930] 1971, p. 250 ).

63. This reflects two factors: a central bank cannot turn to a "lender of last resort" if its reserves are deficient; a central bank does not maximize profits and thus may keep higher reserves than otherwise (Keynes [1930] 1971, p. 252).

64. In the British banking system there is little interest-rate competition (Kcynes [1930] 1971, p. 254).

65. J. H. Williams, "Monetary Stability and the Gold Standard" (1932) in Williams 1947 covered much the same ground.

66. Keynes argued that this dilemma did not present itself to Great Britain before 1914 because "the influence of London on credit conditions throughout the world was so predominant that the Bank of England could almost have claimed to be the conductor of the international orchestra. By modifying the terms on which she was prepared to lend, aided by her own readiness to vary the volume of her gold reserves and the unreadiness of other central banks to vary the volume of theirs, she could to a large extent determine the credit conditions prevailing elsewhere" (Keynes [1930] 1971, p. 274). However since World War I, the decline of Great Britain's influence on world credit conditions meant that she now faced the dilemma. 
67. See Sayers 1936 and p. 95 for a discussion of how this was frequently done on a de facto basis by the Bank of England in the 1890-1914 period.

68. As in the Tract, Keynes considered the case for a managed money standard with flexible rates but ultimately rejected it because the uncertainty associated with exchangerate fluctuations would impede long-term capital mobility. "If we . . . desire that there should be a high degree of mobility for international lending, both for long and for short periods, then this is, admittedly, a strong argument for a fixed rate of exchange and a rigid international standard" ([1930] 1971, p. 299). Also, see Williams (1947), who recom. mended maintenance of the gold standard as a restraint, setting the "limits to which monetary variation can be carried" but widening the role of discretionary monetary policy (pp. 187-88). Ultimately "the logical end of the evolution of credit management, and the only real hope of solution of the conflict between external and internal stability, would be closer cooperation of central banks looking toward some form or degree of supernational management" (p. 190).

69. Whale cited evidence of rapid price adjustment between Lancashire and the rest of England, and between England and Scotland.

70. Ford argued that accounting for real-income changes would also explain Taussig's puzzle, "that periods of active lending have been characterized by rising prices rather than falling prices and that the export of goods apparently has taken place, not in conjunction with a cheapening of goods in the lending country, but in spite of the fact that its goods have seemed dearer at times of great capital export" (Taussig [1927] 1966, p. 219).

71. Ford does not entirely dismiss the role of price changes, but doubts that the elasticities are high enough or prices flexible enough to carry the full burden (1962, p. 12; 1977, p. 17).

72. Ford estimated the marginal propensity to import at about 0.3 and the marginal propensity to save at 0.1 to 0.2 . This produces an open-economy multiplier of 2 to 2.5 which is not sufficient to equilibrate the balance of payments (1962, p. 54).

73. Following Keynes ([1923] 1971) and Bloomfield (1959), Ford argued that the rules of the game were followed only by creditor countries, and not even by all of them (1962, p. 16). Britain's playing by the rules was facilitated by the location in London of the world's principal capital and gold markets (pp. 11-12).

74. This evidence is contrasted to Ford's finding, unfavorable to the classical relativeprice mechanism, that "the cyclical behavior of the net barter terms of trade shows no such consistent pattern" (1962, p. 76).

75. Favorable circumstances for Britain other than the institutional environment stressed by Ford were: confidence in the convertibility of sterling, the alternating pattern of trends in home and foreign investment, and the sensitivity of British exports to British overseas lending (1962, p. 190).

76. "The price level in the U.S. relative to that in Britain rose from 89.1 to 91.l" (Friedman and Schwartz 1963, p. 98).

77. However one conspicuous example, discussed by Friedman and Schwartz, when the classical approach could not fully explain the adjustment mechanism, was the period 1896-1901.

78. A study by Macesich (1960), using a similar approach, demonstrated that the monetary instability in the period 1834-45 was not caused primarily by the Bank war and Jacksonian policy, as traditionally believed, but rather was produced by external events. Given that the United States was part of the international specie standard, the author argued, internal prices had to adjust to external prices, and how they did so did not matter. Macesich isolated the different determinants of monetary change and found that changes in the ratio of the public's holdings of deposits-plus-notes to specie and the ratio of the bank's liabilities to specie explained most of the change in the money supply reflecting uncertainty engendered by the Bank war. The approach of Temin (1969), based on different data 
sources, was similar to Macesich's, but attached greater importance to changes in highpowered money, and less to the ratios, in explaining monetary movements.

79. Following Keynes ([1923] 1971, [1930] 1971) and Cassel (1935), Triffin doubted the strength of the long-term equilibrating forces of the commodity theory of money and termed the gold discoveries of the nineteenth century favorable accidents temporarily reversing a tendency to secular deflation. Instead, "the reconciliation of high rates of economic growth with exchange-rate and gold-price stability was made possible by the rapid growth and proper management of bank money, and could hardly have been achieved under the purely, or predominantly, metallic systems of money creation characteristic of the previous centuries" (Triffin 1964, p. 15). Triffin (1960) foresaw that a gold-exchange standard based on key currencies, such as that which dominated the interwar and the post-World War II periods, would ultimately fail because of a growing threat to the convertibility of the key currencies as their use as international reserves increased.

80. See similar approaches by Abramovitz (1973) and Thomas (1973).

81. In the postbellum period it was the foreign demand for wheat that was the key source of the long swing. Williamson's interpretation of the 1830s differs markedly from that of Macesich and Temin (n. 78 above) who each stressed the role of external monetary forces as the key disturbing factor.

82. However, the evidence to date on commodity arbitrage, based on more recent evidence, is far from conclusive, with the majority of studies casting doubt on its effectiveness for other than internationally traded commodities (see Kravis and Lipsey 1978).

83. "When two (or more) countries are on the gold standard then there exist definite limits for the absolute differences between their short-term interest rates. The actual differences at a given moment depend on the absolute stand of the exchange rates at the same moment, which in turn can vary only between the gold points of the currencies. . . . When the interest rates of two countries con form, then we say that their money markets are in a state of solidarity; when the differentials do not conform with the respective absolute positions of the exchange rates, i.e., when they exceed the respective "permissible limits," then we say that they violate that solidarity ... the principles of the gold standard" (Morgenstern 1959, pp. 166-68).

84. Morgenstern explicitly rejected the available data on gold movements because his study (1955) found them to be unreliable. In that study, using official data of imports and exports of gold coin and bullion for the United States, Great Britain, Germany, France, and Canada and a sample of four years, 1900, 1907, 1928, and 1935, official gold exports from one country did not square with gold imports for another.

85. "Without examining the future exchange prices, the author cannot make a case that the maximum permissible interest rate differentials were in fact violated. For the market will respond to the best opportunity. If New York interest went to a $1 \%$ premium over London, Morgenstern would say the market was not operating perfectly. Yet with a premium on spot exchange, it would be perfectly consistent with the operations of a competitive market. The question of interest differentials which exceed the maximum exchange risk then involves the interest parities of forward exchange rates. Morgenstern did not examine this at all" (Borts 1964, p. 227).

86. However, a similar test for Canada revealed no correlation (Bloomfield 1963, p. 65).

87. For Canada and Sweden, merchandise exports in real terms also showed long swings that tended to lead those in other variables.

88. Scammel (1965) echoed this view by stating "it is, in the writer's view, arguable that the gold standard was in fact quasi-organizational, being operated by a team of central bankers cooperating under the leadership of the Bank of England on behalf of the world business community" (p. 34).

89. Foreign-exchange reserves accounted for 19 percent of total world reserves in 1913. Japan, Russia, and India held the largest fraction of their reserves in sterling. 
90. Of four effects of a rise in discount rate to correct the balance of payments, Lindert ruled out the effect on aggregate demand as involving too lengthy a lag to account "for the remarkable smoothness and rapidity with which exchange rates, international gold flows, and gold reserves of central banks seem to have been altered." Moreover he found the lag between changes in Bank rate and import prices also to be too long to be relevant, and the evidence on the effect on new issues of long-term foreign securities to be unclear. Hence only the effect on short-term funds operated as the key channel of influence of Bank rate (1969, pp. 43-47).

91. As a test of the relative "pulling" power of the different currencies, Lindert (1969, p. 50) regressed each exchange rate on the other two exchange rates, on its own discount rate, and the second center's rate. He found a hierarchy of dominance running from London to Paris to Berlin.

92. Quotation from the Macmillan report (1931,p. 125) in Lindert 1969, p. 49. The fact that London and the other centers could maintain "deficits without tears" in the pre-World War I period ultimately led to a weakening of the balance-of-payments adjustment mechanism because the longer the process continued, the more difficult it became "to undertake the contractionary measures that would have been required to restore payments "equilibrium" " (Lindert 1969, p. 79). Also see Triffin 1960.

93. Additional methods used were the outright sale or purchase of securities, selling consols spot and buying for the account, borrowing in the market, borrowing from clearing banks, borrowing from special depositors, and moral suasion.

After 1878, the Bank lent to its own customers at the market rate of interest, while at the same time it charged discount houses a penalty rate above the market rate. "The position of the penal rate was ordinarily a matter of daily concern and therefore influential over the market rate itself" (Sayers 1951, p. 115).

94. Goodhart's analysis follows closely that of Whale (1937). Both Goodhart's and Whale's results can be reinterpreted as consistent with the monetary approach to the balance of payments. According to that approach, a rise in economic activity in an open economy such as Great Britain would generate an excess demand for money that would be satisfied in part by a gold inflow. Indeed Mills and Wood (1978), applying the Granger-Sims causality test to the pre-World War I U.K. money supply and national-income data, found that income caused money, evidence that they considered sympathetic to the monetary approach.

95. Also see A. G. Ford (1977, p. 42), who cites similar evidence on investment activity.

\section{References}

Abramovitz, Moses. 1973. The monetary side of long swings in U.S. economic growth. Memorandum no. 146, Stanford University Center for Research on Economic Growth. Mimeo.

Andrew, A. P. 1907. The Treasury and the banks under Secretary Shaw. Quarterly Journal of Economics 21 (Aug.): 519-68.

Angell, J. W. [1925] 1965. The theory of international prices. Reprint. New York: Augustus M. Kelley.

Bagehot, W. [1873] 1969. Lombard Street. Reprint of the 1915 edition. New York: Arno Press. 
Beach, W. 1935. British international gold movements and banking policy, 1881-1913. Cambridge: Harvard University Press.

Bloomfield, Arthur I. 1959. Monetary policy under the international gold standard. New York: Federal Reserve Bank of New York.

- 1963. Short-term capital movements under the pre-1914 gold standard. Princeton Studies in International Finance, no. 11. Princeton: Princeton University Press.

- 1968. Patterns of fluctuation in international investment before 1914. Princeton Studies in International Finance, no. 21. Princeton: Princeton University Press.

Bordo, M. D. 1975. John E. Cairnes on the effects of the Australian gold discoveries, 1851-73: An early application of the methodology of positive economics. History of Political Economy 7 (no. 3): 337-59.

- 1983. Some aspects of the monetary economics of Richard Cantillon. Journal of Monetary Economics 12 (Aug.): 235-58.

Borts, G. H. 1964. Review of International financial transactions and business cycles, by O. Morgenstern. Journal of the American Statistical Association 59 (Mar.): 223-28.

Brown, William A. 1940. The international gold standard reinterpreted, 1914-1934. New York: National Bureau of Economic Research.

Bullion report. 1810. See Report . . . on the high price of bullion [1810] 1978.

Cairncross, Alec K. 1953. Home and foreign investment, 1870-1913. Cambridge: Cambridge University Press.

Cairnes, J. E. [1873] 1965. Essays in political economy: Theoretical and applied. Reprint. New York: Augustus M. Kelley.

Cantillon, R. [1931] 1964. Essai sur la nature du commerce en général. Ed. H. Higgs. Reprint. New York: Augustus M. Kelley. (First published 1755.)

Cassel, Gustav. 1935. The downfall of the gold standard. Oxford: Clarendon Press.

Chevalier, M. 1859. On the probable fall in the value of gold! The commercial and social consequences which may ensue, and the measures which it invites. Translated from the French by Richard Cobden. 3d ed. Manchester: A. Ireland.

Cunliffe report. [1918] 1979. See United Kingdom, Parliament [1918] 1979.

Dick, Trevor. 1981. Canadian balance of payments, 1896-1913: Mechanisms of adjustment. Mimeo.

Fetter, Frank W. 1965. The development of British monetary orthodoxy, 1717-1875. Cambridge: Harvard University Press.

. 1953. The Bullion Report re-examined. In Papers in English monetary history, ed. T. S. Ashton and R. S. Sayers. Oxford: Clarendon Press. 
Fisher, I. 1920. Stabilizing the dollar. New York: Macmillan.

. [1922] 1965. The purchasing power of money. Reprint. New York: Augustus M. Kelley.

1935. Are booms and depressions transmitted internationally through monetary standards? Bulletin of the International Statistical Institute 28 (no. 1): 1-29.

Ford, A. G. 1962. The gold standard, 1880-1914: Britain and Argentina . Oxford: Clarendon Press.

- 1977. International financial policy and the gold standard, 18701914. Mimeo.

Frenkel, J. 1971. A theory of money, trade, and the balance of payments in a model of accumulation. Journal of International Economics (May): 159-87.

Friedman, M., and A. J. Schwartz. 1963. A monetary history of the United States, 1867-1960. Princeton: Princeton University Press.

Girton, L., and D. Roper. 1978. J. Laurence Laughlin and the quantity theory of money. Journal of Political Economy 86 (Aug.): 599-625.

Goodhart, C. A. E. 1972. The business of banking, 1891-1914. London: Weidenfield and Nicolson.

Goschen, G. J. [1892] 1978. The theory of the foreign exchanges. Reprint. New York: Arno Press.

Graham, F. D. 1922. International trade under depreciated paper: The United States, 1862-79. Quarterly Journal of Economics 36 (Feb.): 220-73.

Gregory, T. E. [1932] 1979. The gold standard and its future. Reprint. New York: Arno Press.

Hawtrey, R. G. 1935. The gold standard in theory and practice. 5th ed. London: Longmans Green.

Hume, D. [1752] 1955. Of the balance of trade. Reprint. In Writings on economics, ed. E. Rotwein. Madison: University of Wisconsin Press.

Jevons, W. S. [1884] 1964. Investigations in currency and finance. Reprint. New York: Augustus M. Kelley.

Johnson, H. G. 1976. The monetary approach to balance of payments theory. In The monetary approach to the balance of payments, ed. J. Frenkel and H. G. Johnson. Toronto: University of Toronto Press.

Jonung, Lars. 1979. Knut Wicksell and Gustav Cassel on secular movements in prices. Journal of Money, Credit, and Banking (May): 165-81.

Keynes, J. M. [1913] 1971. Indian currency and finance. Vol. 1 of The collected writings of John Maynard Keynes. Reprint. London: Macmillan and New York: Cambridge University Press for the Royal Economic Society.

- . [1923] 1971. A tract on monetary reform. Vol. 4 of The collected writings. See Keynes [1913] 1971. 
- [1930] 1971. The applied theory of money: A treatise on money. Vol. 6 of The collected writings. See Keynes [1913] 1971.

Kindahl, J. K. 1961. Economic factors in specie resumption. Journal of Political Economy 69 (Feb.): 30-48.

Kravis, Irving B., and Robert E. Lipsey. 1978. Price behavior in the light of balance of payments theories. Journal of International Economics 8 (May): 193-246.

Kuhn, T. 1970. The structure of scientific revolutions. $2 \mathrm{~d}$ ed. Chicago: University of Chicago Press.

Laidler, D. 1981. Adam Smith as a monetary economist. Canadian Journal of Economics 14 (May): 185-200.

Laughlin, J. L. 1903. The principles of money. New York: Scribner's.

League of Nations. [1931] 1979. Reports of the gold delegation: Interim report of the gold delegation of the financial committee. Reprint. New York: Arno Press.

Lindert, Peter H. 1969. Key currencies and gold, 1900-1913. Princeton Studies in International Finance, no. 24. Princeton: Princeton University Press.

Macesich, G. 1960. Sources of monetary disturbances in the U.S., 1834 45. Journal of Economic History 20 (Sept.): 407-34.

Macmillan report. 1931. See United Kingdom, Parliament 1931.

Marshall, Alfred. 1923. Money, credit, and commerce. London: Macmillan.

- 1926. Official papers. London: Macmillan.

McCloskey, D. N., and J. R. Zecher. 1976. How the gold standard worked, 1880-1913. In The monetary approach to the balance of payments. See Johnson 1976.

Meier, Gerald M. 1953. Economic development and the transfer mechanism: Canada, 1895-1913. Canadian Journal of Economics and Political Science 19 (Feb.): 1-19.

Mill, J. S. [1865] 1961. Principles of political economy. Reprint. New York: Augustus M. Kelley.

Mills, T. C., and C. E. Wood. 1978. Money-income relationships and the exchange rate regime. Federal Reserve Bank of St. Louis Review 60 (Aug.): 22-27.

Mints, L. 1945. A history of banking theory in Great Britain and the United States. Chicago: University of Chicago Press.

Morgenstern, Oskar. 1955. The validity of international gold movement statistics. Special Papers in International Economics, no. 2. Princeton: Princeton University Press.

_- 1959. International financial transactions and business cycles. Princeton. Princeton University Press.

Mundell, R. 1971. Monetary theory. Pacific Palisades, Calif.: Goodyear. 
Nurkse, R. [1944] 1978. International currency experience. Reprint. New York: Arno Press. (First published by the League of Nations.)

O'Leary, P. J., and W. Arthur Lewis. 1955. Secular swings in production and trade, 1870-1914. The Manchester School 23 (May): 118-25.

Palyi, Malchior. 1972. The twilight of gold, 1914-1936: Myths and realities. Chicago: Henry Regnery.

Pesmazoglu, J. S. 1951. A note on the cyclical fluctuations of British home investment, 1870-1913. Oxford Economic Papers 3 (Feb.): 3961.

Presnell, L. S. 1968. Gold reserves, banking reserves, and the Baring crisis of 1890. In Essays in money and banking in honour of R. S. Sayers, ed. C. R. Whittlesey and J. S. C. Wilson. Oxford: Clarendon Press.

Report from the select committee on the high price of bullion. [1810] 1978. New York: Arno Press.

Ricardo, D. [1811] 1951. High price of bullion: A proof of the depreciation of bank notes. In The works and correspondence of David Ricardo, ed. Piero Sraffa, 3. Cambridge: Cambridge University Press.

- [1816]. 1951. Proposals for an economical and secure currency; with observations on the profits of the Bank of England as they regard the public and the proprietors of Bank stock. In The works and correspondence of David Ricardo. See Ricardo [1811] 1951.

Rich, G. 1978. The cross of gold: Money and the Canadian business cycle, 1867-1913. Mimeo.

Samueison, P. 1971. An exact Hume-Ricardo-Marshall model of international trade. Journal of International Economics 1 (Feb.): 1-11.

Sayers, R. S. 1936. Bank of England operations, 1890-1914. London: P. S. King and Son.

1957. Central banking after Bagehot. Oxford: Clarendon Press.

1951. The development of central banking after Bagehot. Economic History Review, 2d ser., 4 (no. 1): 109-16.

- 1953. Ricardo's views on monetary questions. In Papers in English monetary history. See Fetter 1953.

Scammel, W. M. 1965. The working of the gold standard. Yorkshire Bulletin of Economic and Social Research 17 (May): 32-45.

Silverman, A. G. 1931. Some international trade factors for Great Britain, 1880-1913. Review of Economics and Statistics 13 (Aug.): 114-24.

Smit, J. C. 1934. The pre-war gold standard. Proceedings of Academy of Political Science 13 (Apr.): 53-61.

Smith, A. [1776] 1976. An inquiry into the nature and causes of the wealth of nations. Reprint. Chicago: University of Chicago Press.

Taussig, F. W. 1917. International trade under depreciated paper, a contribution to theory. Quarterly Journal of Economics 21 (May): $380-403$. 
Taussig, F. W. [1927] 1966. International trade. New York: Augustus M. Kelley.

Temin, P. 1969. The Jacksonian economy. New York: W. W. Norton. Thomas, B. 1973. Migration and economic growth. $2 \mathrm{~d}$ ed. Cambridge: Cambridge University Press.

Thornton, H. [1802] 1978. An inquiry into the nature and effects of the paper credit of Great Britain. Fairfield, N.J.: Augustus M. Kelley.

Tinbergen, J. 1950. Business cycles in the United Kingdom, 1870-1914. $2 \mathrm{~d}$ ed. Amsterdam: North-Holland.

Triffin, Robert. 1960. Gold and the dollar crisis. New Haven: Yale University Press.

- 1964. The evolution of the international monetary system: Historical reappraisal and future perspectives. Princeton Studies in International Finance, no. 12. Princeton: Princeton University Press.

United Kingdom. Parliament. [1918] 1979. First interim report of the committee on currency and foreign exchanges after the war. Cmnd. 9182. Reprint. New York: Arno Press.

- 1931. Report of the committee on finance and industry. (Macmillan report). Cmnd. 3897. London: HSMO.

Viner, Jacob. 1924. Canada's balance of international indebtedness, 1900-1913. Cambridge: Harvard University Press.

_. [1937] 1975. Studies in the theory of international trade. Reprint. New York: Augustus M. Kelley.

- 1932. International aspects of the gold standard. In Gold and monetary stabilization, ed. Q. Wright. Chicago: University of Chicago Press.

Whale, P. Barrett. 1937. The working of the pre-war gold standard. Economica 4 (Feb.): 18-32.

White, H. D. 1933. The French international accounts, 1880-1913. Cambridge: Harvard University Press.

White, L. H. 1981. Free banking in Britain: Theory, experience, and debate, 1900-1945. Ph.D. diss., University of California at Los Angeles.

Wicksell, Knut. [1898] 1965. Interest and prices. Reprint. New York: Augustus M. Kelley.

Williams, D. 1968. The evolution of the sterling system. In Essays in money and banking in honour of R. S. Sayers. See Presnell 1968.

Williams, John. 1920. Argentine international trade under inconvertible paper money, 1800-1913. Cambridge: Harvard University Press.

. 1947. Gold and monetary stabilization. In Postwar monetary plans and other essays. New York: Knopf.

Williamson, Jeffrey G. 1964. American growth and the balance of payments, 1820-1913. Chapel Hill: University of North Carolina Press. 
1961. International trade and U.S. economic development

1827-1843. Journal of Economic History 21 (Sept.): 372-83.

. 1963. Real growth, monetary disturbances, and the transfer

process: The U.S., 1879-1900. Southern Economic Journal 29 (Jan.):

$167-80$.

\section{Comment C. Knick Harley}

Michael Bordo has certainly presented an extensive review of some two centuries of thought on the workings of a currency either consisting of specie or based on notes freely convertible into specie. I have learned a great deal about the evolution of ideas from the 160 pages and 446 footnotes in the version of the paper I have worked with. Certainly I do not have the qualifications, the time, nor the inclination to discus individual economists or even individual schools of thought in comparable detail. Rather I would like to highlight some major themes that run through the literature. In particular, I would like to try to shift the emphasis of the discussion toward the last fifty or a hundred years and stress what Viner called "the international mechanism" partially in its theoretical context but especially within the context of the process of foreign lending in the late nineteenth century.

Two issues have always dominated discussion of the gold standard. The first considers the determinants of the value of the standard in terms of other commodities and the stability of that value over time. The second considers the nature of international equilibrium and the relationships among the prices of various commodities in various locations or countries that equilibrium requires. Central to this discussion is the comparison of equilibria under differing underlying conditions and also investigation of dynamics of adjustment when underlying conditions alter. I intend to add nothing to the discussion of the value of the standard, but will state the obvious: The fluctuations of the value of the standard over the last two-thirds of a century make the concerns of Marshall, Fisher, and their contemporaries seem rather trivial.

To my mind the most interesting literature relating to the gold standard deals with what can broadly be called, after Viner, "the international mechanism." Unfortunately, I am disappointed by Michael Bordo's treatment of the literature that has grown up over the past half century. In particular I am surprised that so little attention has been paid to Viner's

C. Knick Harley is professor of economics at the University of Western Ontario, London, Ontario, Canada. 
Studies in the Theory of International Trade (six footnote references, most apparently as an afterthought) which has always seemed to me to have been the most thorough and considered statement of the traditional position as it emerged between the wars. Along the same lines I miss any discussion of the theoretical literature on transfers and reparations (Keynes [1929] 1949; Ohlin [1929] 1949; Samuelson 1952, 1954). Finally, more should be said about the literature on the "Atlantic economy" that has appeared since the Second World War. I would, therefore, like to use the few minutes at my disposal to present what I see to have been the issues raised by these strands of literature and thus highlight what I believe to be major issues that should remain in our research agenda.

The literature on the "international mechanism" contained two strands to which I have already referred. First, there is the real theory of comparative-static comparison of international equilibria. Second, there is discussion of what we would now call macroeconomic processes involved in moving between equilibria. Now these two issues were often not clearly separated in the literature and Ohlin ([1929] 1949, p. 179, n. 3) was moved to remark (and was echoed by Samuelson), "Professor Taussig seems to me to present two different and incompatible theories: (1) the barter theory of Mill; (2) a theory of the monetary and price mechanism." Ohlin, of course, proceeded to explain the real (barter) theory in a manner that was quickly recognized to be correct. At the same time he left the "theory of the monetary and price mechanism" to "Professor Viner, with whom I am in substantial agreement." Ohlin demonstrated that the older supposition, which underlay much of the work by Taussig and his followers, that the real transfer implied a shift in terms of trade against the paying country, was incorrect. The comparative statics of the transfer problem under a considerable range of conditions is now firmly understood and is presented with his characteristic lucidity by Samuelson $(1952,1954)$.

Even if errors in identifying the conditions of new equilibrium are avoided, issues of the (macroeconomic) adjustment to the new equilibrium in a complex monetary economy remain. First, the transfer mechanism involves a reduction of "total buying power" in the sending country and an increase in the receiving country. In addition new equilibrium will normally require relative price adjustments, although as Ohlin demonstrated, the adjustment in the relative prices of traded goods is smaller and less predictable than earlier writers imagined. Furthermore, in a world where transportation costs result in a considerable portion of national product being untraded, resources wil have to be redirected toward (or away) from traded goods in the sending (receiving) economy, presumably through the mechanism of relative price changes. The final equilibrium will require a lower money stock in the sending country and a higher stock in the receiver. Discussion of the monetary aspects of the 
adjustment mechanism consists of attempts to discover the processes that are involved in these adjustments. Furthermore, most investigators seem to believe that alteration of relative prices is not frictionless and can be expected to affect both employment and the general price level during a period of adjustment. Thus Keynes ([1929] 1949, p. 167) characterized those who see no such adjustment prlblems as "applying the theory of liquids to what is, if not a solid, at least a sticky mass with strong internal resistance." Discussion of the operation of the gold standard in the short run must now proceed among the other battles in the arena of short-term macroeconomic adjustment where heroes of flexibility confront gladiators of rigidity.

Historical fact-as well perhaps as historical myth-maintains scholars' interest in the late-nineteenth-century gold standard. The international economy seems to have experienced less short-run instability than either theoretical models or twentieth-century experience would suggest. Britain, in particular, seems to have succeeded in maintaining enviable short-run stability despite recurring real shocks in the form of large periodic fluctuations in foreign investments that reflected the cycles in expansion in areas of recent settlement. For example, in 1903 foreign investment was about 2.5 percent of British GNP, but by 1913 it had grown to some 7 percent. Now the remarkable feature of these cycles to Taussig and his students when they discovered them and to subsequent investigators who believe in "sticky mass" theories of short-term adjustment was both the near absence of fluctuations in unemployment and inflation and the absence of monetary crises despite Britain's fractional reserve banking system.

What happened factually is clear enough. First, the balance of payments adjusted rapidly, primarily through fluctuations in exports, so that an increase in foreign lending from about $£ 50$ million in 1903 to well over $£ 200$ million in 1913 was transferred abroad without significant gold flows and thus without placing any noticeable strain on the Bank of England's gold holdings that were always well under $£ 40$ million. Thus loans were transferred without monetary strain. Second, as Cairncross (1953) demonstrated, fluctuations in employment and the domestic price level were largely avoided because domestic investment, particularly building, declined as exports rose in response to foreign investment and then displaced exports as the latter declined when foreign investment declined.

Now it is obvious to anyone who examines the evidence that the international system could not have worked in the manner postulated by the simplest version of the gold standard adjustment mechanism. That is to say, the increase in lending could not possibly have been initially transferred in gold and the real transfer then been effected by gradual price adjustments. In the first place there was insufficient gold in Britain, and in the second the adjustment seems too rapid. 
The historical literature, it seems to me, is best seen as trying to understand this adjustment. One strand has paid attention to short-run capital flows and the use of British balances as a substitute for gold as the mechanism that allowed fluctuating capital flows in the face of very moderate gold movements. That explanation, however, does not seem to offer any strong mechanism acting in Britain to effect the real transfer, nor does it help to explain how sterling in its role as a reserve currency avoided the problems of sterling since the First World War or of the dollar since 1960.

A second major strand in the literature has maintained that the capital movements were not exogenous shocks but part of a wider process of growth in the Atlantic economy as a whole. The working out of that process of growth involved simultaneously changes in the composition of production in the borrowing and lending country necessary to effect the real transfer and the capital flow in financial terms. In this tradition I would obviously include Brinley Thomas's and Jeffrey Williamson's work. I would also draw attention to a very interesting theoretical article by George Borts (1964).

Others like A. G. Ford argue that while long-run forces in the expanding international economy aided adjustment, it is probably somewhat misleading to focus exclusively on Britain's stability. Their argument would run that there were inflationary periods alternating with financial crises and deflation, but the international market for short-term funds insulated Britain and forced the instability onto the periphery.

I remain agnostic about the mechanism that smoothly allocated resources alternately between building houses in Oldham and Oklahoma over at least a half century. Until we understand that mechanism, we must take care in drawing conclusions about the classical gold standard. Perhaps, as H. J. Habakkuk (1962) has argued, there was not a mechanism but rather chance. It seems more likely to me that there were elements of the systematic relationships suggested in the literature, but these may well have been peculiar to their own historical situation. It certainly seems that the international transfer of capital within the late nineteenth century has been and should remain central to our study and understanding of the workings of the gold standard. More central, I would argue, than Michael Bordo's summary allows.

Finally, I cannot concur with Bordo's vision of McCloskey and Zecher's (1976) article as a Copernican revolution in our thinking about the gold standard. Certainly they have made some useful arguments about what sorts of disequilibria are possible. But they have not considered what is to my mind the major issue of the adjustment mechanism in the late-nineteenth-century gold standard that I have just discussed at length. Finally, I have been unable to resist reading a few sentences of Viner (1937, pp. 316-17) to them: 
The classical school and its important followers all held the same views on this point: after allowance for transportation costs, the market prices of identical transportable commodities must everywhere be equal or tend to be equal when expressed in or converted to a common currency. When, therefore, critics of the classical theory have taken it to task on the grounds that it explained the adjustment of international balances by the influence on the course of trade of divergent market prices in different markets of identical transportable commodities . . . they have misinterpreted the classical doctrine.

\section{References}

Borts, George H. 1964. A theory of long-run international capital movements. Journal of Political Economy 72 (Aug.): 341-59.

Habakkuk, H. J. 1962. Fluctuations in house-building in Britain and the United States in the nineteenth century. Journal of Economic History 22 (June): 198-239.

Keynes, J. M. [1929] 1949. The German transfer problem. Reprint. In Readings in the theory of international trade, ed. H. S. Ellis and L. S. Metzler. Philadelphia: Blakiston. (First published in Economic Journal 39 [Mar.]: 1-7.)

McCloskey, D. N., and J. R. Zecher. 1976. How the gold standard worked, 1880-1913. In The monetary approach to the balance of payments, ed. J. Frenkel and H. G. Johnson. Toronto: University of Toronto Press.

Ohlin, B. [1929] 1949. Transfer difficulties, real and imagined. Reprint. In Readings in the theory of international trade, ed. H. S. Ellis and L. S. Metzler. Philadelphia: Blakiston. (First published as The reparation problem: A discussion, in Economic Journal 39 [June]: 172-78.)

Samuelson, Paul A. 1952. The transfer problem and transport costs: The terms of trade when impediments are absent. Economic Journal 62 (June): 278-304.

- 1954. The transfer problem and transport costs II: Analysis of effects of trade impediments. Economic Journal 64 (June): 264-89. Viner, Jacob. [1937] 1975. Studies in the theory of international trade. Reprint. New York: August M. Kelley.

\section{General Discussion}

ABramovitz emphasized and endorsed the view that a central mystery concerning the adjustment mechanism under the international gold standard lies in reconciling the relative freedom enjoyed by Great Britain from the long swings in aggregate economic activity that characterized 
the United States with the magnitude of international capital movements in the nineteenth century.

FriedmAN elaborated upon the issue raised by Abramovitz by referring to the findings of a study that Anna Schwartz and he recently completed on monetary trends in the United States and the United Kingdom. One of their most surprising findings was the independence of phase-cycle-tophase-cycle movements in real income in Great Britain from events in the United States. Friedman and Schwartz had been unable to find any systematic factors explaining real-income fluctuations in Britain. Friedman suggested that this phenomenon was precisely the one cited by Abramovitz.

MCCLOSKEY responded to a point raised by Harley. He noted in several of the papers at the conference a definition of equilibrium in the international affairs of nations that is both artificial and a potential source of confusion. According to that definition, a country's international affairs are in equilibrium only when the balance of payments is zero or, in a more extreme version, when the current-account balance is zero. In fact, countries can maintain surpluses or deficits in their balance of payments for periods of decades or longer. This is evident in the recent experience of Japan, for example. Similarly, countries sometimes go for centuries with surpluses or deficits in their trade balances. Thus, a zero trade balance or zero current-account balance may not be a useful definition of equilibrium.

ZECHER, commenting on David Hume's methodology, pointed out that though Hume may have believed in the law of one price as always in effect, yet he might still ask what would happen if prices did differ between countries or regions. For example, he used this method in explaining the law of gravity by starting with a situation where water did not find its own level.

Kochin noted Bordo's exclusion of a notable authority on the gold standard, Adam Smith. He noted also another issue omitted from Bordo's paper, namely, Hume's recognition that one of the purposes of the gold standard is to possess a treasure against the contingency of war.

FRENKEL, commenting on Harley's remarks, was skeptical that one should require a discussion of the gold standard to bring to the forefront the terms of the trade adjustment consequent on the transfer. Frenkel suggested that as far as the gold standard is concerned, the terms-of-trade effect is probably not a central issue, since much of the adjustment mechanism operates through the income-expenditure mechanism à la Ohlin.

Frenkel also asked discussants to define precisely what they meant when referring to the law of one price. In his own discussion of the law of one price, Hume had stated merely that any man who traveled in Europe in his day observed that differences in the prices of commodities between 
one kingdom and another are no greater than such differences between provinces in the same kingdom.

DoRnBUSCH expressed surprise at Frenkel's statement that the transfer issue is not central to the analysis of the gold standard. It is central, he suggested, if we think that relative price changes are part of the gold standard adjustment mechanism.

WHITE offered a supplement to Bordo's discussion of the classical period in which Bordo considers Ricardo and Mill but omits the currency-banking school controversy. White suggested that Bordo's account of the Act of 1844 relies too heavily on the arguments of its advocates. It may be misleading to say that the currency school wished to combine the automaticity of the gold standard with the capital savings of a fiduciary currency, since in fact the Act of 1844 was not required in order to accomplish that goal. Simply permitting the existence of an unregulated financial system with fractional reserve banking would have been sufficient to achieve that goal. White argued that the currency school's principal complaint was that the gold standard was insufficiently automatic; they sought to eliminate what they saw as a slippage between exports of gold and reductions of the quantity of money.

White went on to argue that the so-called banking school was made up of two distinct sets of opponents of the Act of 1844. Bordo indicates that the opponents of the act favored free competition, but in fact certain members of the banking school, such as Thomas Tooke, were quite hostile to free competition in banking and sympathetic with the Bank of England's monopoly. At the same time, there were other opponents of the Bank Act, best referred to as the free banking school, who advocated free competition in banking. The free banking school had a monetary theory of the trade cycle and blamed the Bank of England for the economy's cyclical instability. Tooke, on the other hand, had a nonmonetary theory and placed little of the blame on the Bank of England.

BoRDo concurred with Frenkel's view that the transfer problem was not central to the gold standard story. He accepted White's interpretation of the existence of divisions within the banking school. 
